\title{
Soy, Soy Foods and Their Role in Vegetarian Diets
}

\author{
Gianluca Rizzo ${ }^{1, *}$ (1) and Luciana Baroni ${ }^{2}$ \\ 1 Via Venezuela 66, 98121 Messina, Italy \\ 2 Primary Care Unit, Northern District, Local Health Unit 2, 31100 Treviso, Italy; luciana_baroni@yahoo.it \\ * Correspondence: gianlucarizzo@email.it; Tel.: +39-320-897-6687
}

Received: 8 November 2017; Accepted: 3 January 2018; Published: 5 January 2018

\begin{abstract}
Soy is a basic food ingredient of traditional Asian cuisine used for thousands of years. In Western countries, soybeans have been introduced about a hundred years ago and recently they are mainly used for surrogate foods production. Soy and soy foods are common nutritional solutions for vegetarians, due to their high protein content and versatility in the production of meat analogues and milk substitutes. However, there are some doubts about the potential effects on health, such as the effectiveness on cardiovascular risk reduction or, conversely, on the possible disruption of thyroid function and sexual hormones. The soy components that have stimulated the most research interest are isoflavones, which are polyphenols with estrogenic properties highly contained in soybeans. In this review, we discuss the characteristics of soy and soy foods, focusing on their nutrient content, including phytoestrogens and other bioactive substances that are noteworthy for vegetarians, the largest soy consumers in the Western countries. The safety of use will also be discussed, given the growing trend in adoption of vegetarian styles and the new soy-based foods availability.
\end{abstract}

Keywords: soy foods; vegetarian diets; phytoestrogens; isoflavones; protein quality; meat analogues; thyroid health; endocrine disruptor; selective oestrogen receptor modulator; cancer

\section{Introduction}

In the last decades, vegetarian diets have become more widespread among the population. The reasons for this choice are different and include mainly ethical, ecological and health aims [1-3].

Shift from omnivore to vegetarian diet implies the intake of nutrients from plant sources with sustainable and well-planned dietary schemes [4]. Some supplements are needed to ensure adequate nutrition if the diet falls to guarantee correct essential nutrients. Overall, the most important and accepted supplement is the vitamin B12 supplementation, scarcely represented in plant foods [4]. Also protein quality has often been a cause for debate because of different amino acid pattern of plant foods in relation to animal ones, which has been speculated to affect protein synthesis; this concept led to the definition of "high quality protein" referred to proteins from animal foods [5]. However, increasing variety and quantity of plant foods may overcome this issue and may guarantee the intake of all essential amino acids needed for an adequate nutrition plan [6,7]. Essential amino acid consumption needs more emphasis in children and individuals engaging in sport activity, with specific increased turnover in body proteins [8-10].

Increasing interest over the last years has been paid to protein from plant sources: there is evidence that individuals consuming foods high in vegetable proteins (i.e., legumes) have lower risk of cardiovascular disease and other metabolic disorders [11,12]. Among others, protein quality of soy beans is one of the most attractive reasons for the interest in soy and soy foods among vegetarians [13]. With the growing adoption of vegetarian lifestyles, a great variety of soy-based food products have become more available in grocery stores; besides the market request, a reason for such popularity may depend on the nutritional and versatile properties of soy beans, which are suitable for food 
technological transformations [14]. Soy beans are used for the production of several analogues and surrogates of meat and dairy products that might be used as alternatives especially during transition to vegetarian diet [13].

High protein content, together with lower carbohydrate content, characterizes soy as an unique vegetable protein source compared to other legumes [10]. Nutrient composition of some legumes, including soy beans, is summarized in Table 1.

Table 1. Vegetable protein sources from legumes ${ }^{1}$.

\begin{tabular}{ccccccccc}
\hline Food & Energy $^{\mathbf{2}}$ & Protein $^{\mathbf{3}}$ & Carbohydrate $^{\mathbf{3}}$ & Fats $^{3}$ & Fibre $^{\mathbf{3}}$ & PUFA $^{\mathbf{3 , 4}}$ & Iron $^{\mathbf{5}}$ & Calcium $^{\mathbf{5}}$ \\
\hline Azuki beans & 329 & 19.87 & 62.90 & 0.53 & 12.7 & 0.113 & 4.98 & 66 \\
Fava beans & 341 & 26.12 & 58.29 & 1.53 & 25.0 & 0.627 & 6.70 & 103 \\
Chickpeas & 378 & 20.47 & 62.95 & 6.04 & 12.2 & 2.731 & 4.31 & 57 \\
Green peas & 352 & 23.82 & 63.74 & 1.16 & 25.5 & 0.495 & 4.82 & 37 \\
Kidney beans & 333 & 23.58 & 60.01 & 0.83 & 24.9 & 0.457 & 8.20 & 143 \\
Lentils & 352 & 24.63 & 63.35 & 1.06 & 10.7 & 0.526 & 6.51 & 35 \\
Lima beans & 338 & 21.46 & 36.38 & 0.69 & 19.0 & 0.309 & 7.51 & 81 \\
Lupins & 371 & 36.17 & 40.37 & 9.74 & 18.9 & 2.439 & 4.36 & 176 \\
Mug beans & 347 & 23.86 & 62.62 & 1.15 & 16.3 & 0.384 & 6.74 & 132 \\
Mungo beans & 341 & 25.21 & 58.99 & 1.64 & 18.3 & 1.071 & 7.51 & 138 \\
Navy beans & 337 & 22.33 & 60.75 & 1.50 & 15.3 & 0.873 & 5.49 & 147 \\
Peanuts & 567 & 25.8 & 16.13 & 49.24 & 8.5 & 15.558 & 4.58 & 92 \\
Pinto beans & 347 & 21.42 & 62.55 & 1.23 & 15.5 & 0.407 & 5.07 & 113 \\
Soy beans & 446 & 36.49 & 30.16 & 19.94 & 9.3 & 11.255 & 15.70 & 277 \\
\hline${ }^{1}$ From USDA Food Composition Databases [15]. ${ }^{2}$ Kcal per 100 g. ${ }^{3}$ g per 100 g. ${ }^{4}$ PUFA: polyunsaturated fatty \\
acids. ${ }^{5}$ mg per 100 g.
\end{tabular}

Furthermore, the production of protein sources from plants can be a sustainable option for reducing the ecological exploitation of natural sources during cattle breeding for meat production $[13,16]$.

Besides macro- and micronutrients, soy contains high concentrations of phytoestrogens, polyphenols with similar molecular structure as endogenous oestrogens, which still raise doubts about safe use, especially at high dose [17]. In Asian regions, soy is often used for several traditional cuisine dishes. Soy beans can be blended and heated to extract soy milk that can also be treated with magnesium chloride or calcium sulphate curd to get tofu. In addition, different fermentation treatments are useful in order to get natto, tempeh, soy sauce and sufu [18].

The high consumption of soy foods and, consequently, isoflavones in Asian populations dissipated critical concerns on safety; however, their use in Western countries and their role on human health is still debatable [19-21].

In this review we discuss worldwide consumption, nutrient composition and bioactive compounds in soy and soy foods. Furthermore, we discuss current evidence of the possible effects on human health and safety. These arguments are relevant for Western countries with growing soy consumption, especially by vegetarians [22].

A non-systematic literature search of MEDLINE (http:/ /www.ncbi.nlm.nih.gov/pubmed) and EMBASE (http:/ / www.embase.com) was conducted by using the following subject headings/key words or MeSH terms where available: (a) 'soy' OR 'soy foods' OR 'soya' OR 'soy beans' OR 'glycine max' OR 'soy products' OR 'meat analogues' OR 'meat substitutes' OR 'meat alternatives' OR 'texturized vegetable protein' OR 'soy protein' OR 'soy milk' OR 'traditional soy foods'; and (b) 'vegetarian'; and (c) 'consumption' OR 'protein quality' OR 'isoflavones' OR 'phytochemicals' OR 'nutrients' OR 'bioactive compounds' OR 'cancer' OR 'thyroid' OR 'sex hormones' OR 'health benefits' OR 'chronic diseases.' The search was extended to references within.

\section{Soy Consumption}

Major worldwide soy consumers are historically identified in Asian populations. The great consumption in the Asian regions depends on several traditional Asian foods that use soy beans as the 
main ingredient [23-27]. However, in the last decade, consumption of soy foods in Western countries has grown with the increase in vegetarian lifestyle and healthy perception of soy intake [28].

Total grams, soy protein or soy isoflavone intake can be used as indexes of soy consumption, due to relevance of protein and isoflavone fractions and relative variability in soy foods. The intake of $100.6 \mathrm{~g}$ per day, $8.7 \mathrm{~g}$ per day and $39.6 \mathrm{mg}$ per day of soy, soy protein and isoflavones, respectively, have been reported among Chinese women from Shanghai [23]. In perimenopausal cohort of women from Hong Kong, median intake of soy protein was $4.5 \mathrm{~g}$ (despite with great variability across individuals) [29]; however, other studies reported up to $17 \mathrm{~g}$ per day of soy protein intake in Shanghai women with more plant based dietary habits [30]. Among the adult population from Japan, mean soy protein intake ranged between 6 to $11 \mathrm{~g}$ per day with isoflavones intake of 23-54 mg per day [31]. Mean soy, soy protein and soy isoflavone intake in 47 Japanese prefectures between 1980 and 1985 has been reported to be $66.8 \mathrm{~g}, 6.5 \mathrm{~g}$ and $27.8 \mathrm{mg}$, respectively [32]. In Japan, median intake of daidzein and genistein (about $90 \%$ of isoflavone fractions) [33] have been reported to be between 9 and $12 \mathrm{mg}$ per day and 15 and $20 \mathrm{mg}$ per day, respectively [24]. However, decreased intake of soy protein in respect to animal protein occurred in the last decades because adoption of more Westernized habits in Asian countries [31]. In Japanese men, the plasma isoflavone concentration of genistein and daidzein was 493 and $283 \mathrm{nM}$, respectively, whereas in British men (reporting no soy consumption) concentration of these components was 33 and $18 \mathrm{nM}$, respectively [34-36]. In Korea isoflavone intake has been estimated to be about $15 \mathrm{mg}$ per day with about $21 \mathrm{~g}$ of traditional soy foods daily per capita [25]. Women from Samsung Medical Centre at Sungkyunkwan University in Seoul, Korea, recruited for a study of correlation between breast cancer risk and tofu intake from case-control studies, reported median daily intake of 7.4 and $8.5 \mathrm{~g}$ of soy protein among cases and controls, respectively [37]. Median daily tofu intake was between 27 and $36 \mathrm{~g}$.

In USA and Europe, the intake of isoflavones was less than $3 \mathrm{mg}$ per day [38,39]. Usually, isoflavone intakes were estimated to be less than $1 \mathrm{mg}$ per day per capita in Western countries but with a range between $0.3-4.5 \mathrm{mg}$ per day in European countries and about 1 to $3 \mathrm{mg}$ per day in USA [22,36,40-42]. Vegetarians had the major intake among the Western people, with 7-12 mg per day of total isoflavones [22]. In 2002, soy intake was calculated in the 35,955 adults of the European Prospective Investigation into Cancer and Nutrition (EPIC) study on 10 European countries (the UK, The Netherlands, Sweden, Spain, Norway, Italy, Greece, Germany, France and Denmark) [43]. Soy consumption was very low among the European countries, with a total of 681 (1.9\%) participants reporting to consume soy or soy foods and with the higher contribution from UK. Interestingly, a subgroup of individuals of the UK-EPIC arm, classified as following a health-conscious lifestyle (HHL) (defined as non-meat eaters, fish eaters, vegetarians, or vegans) showed the highest soy intake compared to the whole sample: specifically, compared to $1 \%$ of males and $2 \%$ of female among the UK participants in the general population, 35\% of males and $24 \%$ of females among HHL reported soy consumption. UK HHL consumed up to $149 \mathrm{~g}$ per day of soy dairy substitutes with an isoflavone intake of 15-30 mg per day [23-25]. In another British study of women from the Oxford-EPIC cohort, including vegetarian and vegan subgroups, it has been reported an intake up to $30 \mathrm{~g}$ per day of soy protein and $130 \mathrm{mg}$ per day of isoflavones, with most of the highest soy intake in vegetarians or vegans [44]. More recently, a pan-European investigation on polyphenol consumption showed an overall general north-south gradient, with higher intake in Northern European countries. Intake of isoflavones has been reported to be very low in populations living in the Mediterranean area [45]: on average, population living in countries such as Greece, Spain and Italy showed a range of intake from $10 \mu \mathrm{g} /$ day to up to approximately $1 \mathrm{mg} /$ day [46,47]; interestingly, compared to other European countries, the main sources of phytoestrogens in Mediterranean countries have been reported to be legumes (i.e., beans and peas), nuts, fruits, vegetables, grains and seeds [48,49].

In the US, the community of devotees to the Seventh-day Adventist Church is a precious source of epidemiological data for the common adherence to vegetarian, ovo-lacto vegetarian and vegan diets. Furthermore, it is a cohort with homogeneous habits, very useful for the definition and comparison of 
vegetarian nutritional intakes [50,51]. Among soy consumers in Adventist Health Study-2 (from USA and Canada), mean daily soy protein intake was $9.25 \mathrm{~g}$ and $8.42 \mathrm{~g}$, assessed with $24 \mathrm{~h}$ recall and FFQ, respectively [52]. In postmenopausal women, isoflavone intake ranged between 0 and about $1 \mathrm{~g}$ per week [53].

The wide variability of soy foods and soy intakes among diverse populations provides a challenge to define mean consumption; nevertheless, an intake of 10-12 g per day of soy protein seems to be convincing among vegan, with about half of this amount among non-vegan vegetarian [54]. A summary of soy intake estimates is presented in Table 2.

Table 2. Soy consumption per day ${ }^{1}$.

\begin{tabular}{cccc}
\hline Nationality & Soy and Soy Foods $^{2}$ & Soy Protein $^{2}$ & Isoflavones $^{3}$ \\
\hline USA & NA & NA & $0.73-3.3$ \\
Europe & NA & NA & $0.37-4.5$ \\
Vegetarians and soy users & NA & $8.42-9.25$ & $3.2-30$ \\
China & $23.5-135.4$ & $2.5-10.3$ & $6.2-75.7$ \\
Japan & $50.7-102.1$ & $6-11.3$ & $22.6-54.3$ \\
Korea & 21.07 & $7.4-8.5$ & 14.88 \\
\hline 1
\end{tabular}

${ }^{1}$ Adapted from references $[22,25,31,37,43,52] .{ }^{2}$ g. ${ }^{3}$ milligrams. NA: Not available.

\section{Soy Nutrients and Bioactive Compounds}

Soy, Glicine $\max (\mathrm{L}$.$) , is a plant of Asian origin belonging to Fabaceae family. Worldwide producers$ of soy bean are USA, Brazil, Argentina, China and India with world production volumes of 35\%, 28\%, $17 \%, 4 \%$ and $3 \%$, respectively [55]. In the soy industry, after oil extraction, a consistent fraction is used for the production of fodder for livestock [56]. Italy is the European country with the highest production of soy beans, with 933,140 tons per year [55], based on GMO free crops [57] The Minister of Agriculture and Forestry in consultation with the Minister for the Environment, Land and Sea and the Minister of Health to European Commission after actuation of European directive 2015/412 permits member state to adopt measures restricting or prohibiting the cultivation of GMOs in all or part of its territory [58]. GMOs are genetically modified organisms that are specially used for crops to maximize commodities production for food and feed. In Europe fifteen type of GM soy crops are regular registered and allowed [59]. There are some doubts raised from animal studies and in particular upon concomitant use of GMO and herbicides [60]. Even if differences between GM and non-GM soybeans were proposed in relation to health efficacy of bioactive compounds [61], actually there are not sufficient data to definitively consider the impact of GMOs on human health but results from scientific literature prompt to a safe profile of GMOs [62].

Different climatic conditions and different cultivation practices lead to variable bean dimension and isoflavone content [63]. The isoflavone content in soybean from different locations is summarized in Table 3.

Table 3. Isoflavone content in soybean from different cultivation countries ${ }^{1}$.

\begin{tabular}{cc}
\hline Country & Isoflavone per $\mathbf{1 0 0} \mathbf{g}$ \\
\hline Australia & 120.84 \\
Brazil & 99.82 \\
China & 118.28 \\
Europe & 103.56 \\
Japan & 130.56 \\
Korea & 178.81 \\
Taiwan & 85.68 \\
USA & 159.98
\end{tabular}

${ }^{1}$ From USDA Database for the Isoflavone Content of Selected Foods [64]. 
The health effects of soy protein stimulated the interest of scientific research $[65,66]$. Compared to other dietary sources, soy has by the highest content of isoflavones, which has been shown to have possible beneficial health effects $[67,68]$. Beyond isoflavones and soy protein, soy beans are a good source of unsaturated fatty acids, B vitamins, fibre, iron, calcium, zinc and other bioactive compounds that make soy a good candidate for a functional food. Soy fibre content is primarily pectic polysaccharides, a type of vegetal fibre well fermentable by gut microbiota [69]. There are also peptides, such as lunasin (a 43 amino acid peptide) and Bowman-Birk (a 71 amino acid peptide) that are protease inhibitors with negative influence on protein digestion but also with in vitro chemopreventive effect [70-72]. Soybean oligosaccharides have been proposed as prebiotic or sugar alternatives [73-75].

Soybean contains a wide range of phytochemicals such as phytic acid (1.0-2.2\%), sterols $(0.23-0.46 \%)$ and saponins $(0.17-6.16 \%)$ with a wide spectrum of potential health benefits [76]. Fewer studies have focused non-isoflavone phytochemicals, such as saponins [77-80] but with the growing use of soy and soy foods, a more detailed identification and quantification of phytochemicals associated is due [81]. Scarcity of data on non-isoflavone components depends on the great interest that isoflavones aroused for their biological properties.

\subsection{Protein Content and Protein Quality}

One of the concerns of vegetarian diets is the achievement of protein requirements. However, in 2016 the American Dietetic Association (ADA) stated that protein requirements are met if caloric intake reaches recommended levels [82]. Among available plant proteins, soy is the only one that has been shown to have high quality proteins, based on human nitrogen balance studies [83-88]. The protein content of soy bean varies between $36 \%$ and $46 \%$, depending on cultivars [89-91]. Protein quality is an estimation of a single food, often through protein extraction, to obtain information about efficacy in endogenous protein synthesis after the intake. There are several methods developed to define protein quality of foods, mostly based on animal model test, such as Net Protein Utilization (NPU), Nitrogen Balance, Protein Efficiency Ratio (PER), Biological Value (BV) [92] but the most accepted methods nowadays is the Protein Digestibility Corrected for Amino Acid Score (PDCAAS) [93]. Analytical methods for quality protein are summarized in Table 4.

Table 4. Analytical protein quality methods ${ }^{1}$.

\begin{tabular}{cl}
\hline Method & \multicolumn{1}{c}{ Description } \\
\hline Net Protein Utilization (NPU) & $\begin{array}{l}\text { Difference between nitrogen retention in carcass of animal group feed } \\
\text { with test protein and nitrogen content in carcass of animal group with } \\
\text { free protein diet normalized for dietary nitrogen intake. }\end{array}$ \\
\hline Protein Efficiency Ratio (PER) & Gain in body mass of animal model divided for protein intake \\
\hline Nitrogen Balance & $\begin{array}{l}\text { Protein intake requirement to attain nitrogen equilibrium. } \\
\text { The difference between nitrogen intake and nitrogen loss with urine } \\
\text { and faeces (nitrogen absorption and retention). }\end{array}$ \\
\hline Biological Value (BV) & $\begin{array}{l}\text { Nitrogen absorbed form test protein divided for nitrogen incorporated } \\
\text { into the body and standardized for a reference protein. }\end{array}$ \\
\hline True Digestibility & $\begin{array}{l}\text { Difference between nitrogen intake and nitrogen loss corrected for } \\
\text { protein-free diet loss. }\end{array}$ \\
\hline Amino Acid Score & $\begin{array}{l}\text { mg of amino acid in 1 g of test protein divided for mg of amino acid in } \\
\text { requirement pattern. }\end{array}$ \\
\hline $\begin{array}{c}\text { Protein Digestibility corrected for } \\
\text { amino acid score (PDCAAS) }\end{array}$ & Amino acid score multiplied for true faecal protein digestibility. \\
\hline $\begin{array}{c}\text { Digestible Indispensable Amino } \\
\text { Acid Score (DIAAS) }\end{array}$ & $\begin{array}{l}\text { Amino acid score for selected pattern multiplied for true ileal amino } \\
\text { acid digestibility. }\end{array}$ \\
\hline & \begin{tabular}{c}
1 From references [8,92-96]. \\
\hline
\end{tabular}
\end{tabular}


Since 1991, PDCAAS was adopted by World Health Organization (WHO), Food and Agriculture Organization (FAO) and United States Department of Agriculture (USDA), due to the combination of the chemical value of amino acid composition of the test food, with the biological value of true absorbability in its integrity and not only from protein fraction after extraction. For example, BV method implied the use of protein extract, with test animal data and used egg or milk as reference values. PDCAAS uses infant amino acid requirements as reference pattern and digestibility of whole foods from human studies, where available $[8,95,96]$. The maximum value that can be reached is $100 \%$ or 1.00 of PDCAAS, which displays an adequate amount of proteins by a specific food that ensures all the essential amino acids, when the protein intake is provided in appropriate amounts to children aged up to 6 months old (previously at 2 years old but with unsatisfactory information available) and above and adults $[8,95]$. Even if PDCAAS method was used for a long time, there are few studies on soy. The PDCAAS values of soy have been reported to range from 0.91 to 1.00 [10,93,97-99]. Table 5 summarizes data on food protein quality through different methods.

Table 5. Protein quality through different methods ${ }^{1}$.

\begin{tabular}{cccccc}
\hline Source & PDCAAS & Digestibility (\%) & Amino Acid Score & PER & BV \\
\hline Soy & $0.92-1.00$ & $95-98$ & 0.94 & 2.2 & 74 \\
Wheat & 0.25 & $96-99$ & 0.26 & 0.8 & 64 \\
Beef & 0.92 & $94-98$ & 0.94 & 2.9 & 80 \\
Egg & 1.00 & $97-98$ & 1.21 & $3.8-3.9$ & 100 \\
Milk & 1.00 & 95 & 1.27 & $2.5-3.1$ & 91 \\
\hline \multicolumn{7}{c}{}
\end{tabular}

Different amino acid profile and digestibility among soy products depends on fibre and phytate content variability during food processing and these differences may imply small differences in PDCAAS [100]. The accuracy of PDCAAS method has been questioned and it has been suggested that the application of amino acid nitrogen recovery correction factors might mitigate analytical method errors that can represent significant contributors to fluctuation of values, with the consequent improvement in measurement consistency [97]. In a comparison of 3 isolated soy proteins and one soy protein concentrate analysed by two different laboratories, Hughes and co-workers concluded that soy protein had high quality proteins comparable to meat, egg and dairy proteins with a truncated PDCAAS of 1.00 [97]. However, data on true digestibility came from in-vivo rat assay, far from real digestibility during daily human consumption [93].

Protein quality methods have several limitations. Variability between experimental conditions and real habits such as single food or protein isolate intake, absence of antinutrient fractions normally occurring in foods or the effect of other foods in the diet, variability among laboratory procedures, inter or intra variability among test subjects, pre-trial fasting washout phase, limited reliability of faecal losses during non-protein washout, the variable contribution of gut microbiota in nitrogen losses and the use of animal data are common limitations of the analytical procedures [8,92-95]. To overcome some limitations of method actually used, Digestible Indispensable Amino Acid Score (DIAAS) has been proposed for the qualitative definition of food proteins. DIAAS method does not provide truncated values over $100 \%$ and the true digestibility is calculated for single amino acid corrected for ileal and not faecal losses. Moreover, scoring patterns are variable for infants, children or adults with a more precise calibration of this method [96]. At present, the complexity of standardization, especially for human ileal loss data of proteins, does not permit the adoption of this method [101]. Health Canada uses Protein Efficiency Ratio as a standard in evaluation of protein quality [94].

A meta-analysis on nitrogen balance studies, including researches on soy protein sources $[83,87,102]$, demonstrates that there is no significant difference between the intake of vegetal or animal sources to meet nitrogen equilibrium, demonstrating that processed soy proteins are equivalent to animal proteins [99]. Therefore, soy-based vegetable analogues can help to meet protein requirements. 
Soy has been analysed for protein quality and has been found to be very similar to cow milk and egg proteins, traditionally used as standard references [103].

In the Framingham Third Generation Study Cohort, link between dietary proteins and musculoskeletal outcomes were investigated prospectively. Appendicular lean mass and quadriceps strength were positively influenced by protein intakes from legume, diary or animal sources [104]. No associations between dietary proteins and bone mineral mass were showed in this protein replete large cohort. In a previous research from the older Framingham Offspring Cohort, quadriceps strength was positively associated with vegetable proteins but not with meat proteins [105]. Soy protein and whey protein equally supported training-induced lean body mass in respect to training-only group; moreover, soy protein but not whey protein, may protect from oxidative damage [106].

In the Italian Levels of Intake Guide for Nutrients and Energy [107], there was no distinction in protein quality for daily requirements. Taking into account the prevalence of vegetable foods in the Italian diet, as recommended, a mean digestibility of dietary protein has been set to $86 \%$ [107]. Protein quality data could provide a useful way to define optimal foods to meet protein requirements in low income countries, where food availability can be very limited and the choice of adequate protein sources can be vital, especially in terms of energy-protein interaction [8]. In Western countries, protein needs in vegetarian diets can easily be met, particularly if caloric requirements are achieved $[5,92]$. The USDA used APP as acronym for "Alternate Protein Product" to identify products with PDCAAS of at least $80 \%$ using casein as reference protein, with at least $18 \%$ of protein weight per weight $(w / w)$ in fully hydrated state. Examples of APP are soy flours, soy concentrates and isolates, frequently used in processed meat substitutes (vegetarian patty or burger) [108].

\subsection{Isoflavones}

Isoflavones belong to a functional class of non-steroidal phytochemicals called phytoestrogen (which also include lignans and coumestans) that possess a chemical structure and functions similar to animal endogenous oestrogens $[109,110]$. The main isoflavones contained in soy beans are genistein, daidzein and glycitein. Plants synthetize isoflavones by various stimuli of environmental stresses, such as infections or paucity of nutrients [111]. Inhibition of pathogens (phytoalexin activity) and molecular signal in symbiotic interactions (in mycorrhizia and rhizobia) are other areas in which isoflavones play an important role [112-116]. Isoflavones are contained in different legumes, such as soy, kidney beans, navy beans, red clover and Japanese arrowroot called kudzu but only soy beans represent a relevant source [117]. Isoflavones content in soy foods is variable among brands and preparations $[15,64,118]$. Table 6 displays isoflavone content in selected soy foods.

In Canada, isoflavones in soy beans vary from 360 to $2241 \mathrm{mg}$ per $\mathrm{kg}$ [119]. Isoflavones content in soy beans from Romania ranged between 210 and $1340 \mathrm{~g}$ per $\mathrm{kg}$ [120], 1176-3309 mg per kg in USA [121] and 525-986 mg per $\mathrm{kg}$ in India [122]. Temperature and soil moisture are crucial for differential synthesis of soy isoflavones during plant growth, with the highest isoflavone concentrations occurring at low temperatures and high soil moisture, mostly depending by the former [63].

Isoflavones have the ability to interact with oestrogen receptors (ERs) due to structural similarity to $17 \beta$-estradiol [123]. However, isoflavones have a low estrogenic potency compared to estradiol [124]; indeed, the affinity of soy isoflavones for ER $\alpha$ and ER $\beta$ were 1/1000 times and $1 / 3$ times, respectively [125]. The affinity for ERs is higher for genistein than daidzein [125-127].

It has been suggested that soy isoflavones may act as selective tissue estrogenic activity regulators (STEAR) and selective oestrogen receptor modulator (SERM), with different mechanisms than direct interaction with receptor [128-131]. Phytoestrogens produce estrogenic, anti-estrogenic or no activity depending upon the tissue [132,133]. ER $\alpha$ and ER $\beta$ display distinct expression patterns in male and female, thus phytoestrogens do not exert their activity as classical oestrogen agonists [134]. Moreover, as a polyphenol subclass, soy isoflavones may have potential antioxidant properties, an essential function in plant management of oxidative stress during photosynthesis [135]. 
Table 6. Isoflavone content in soy foods ${ }^{1}$.

\begin{tabular}{cc}
\hline Food & mg per 100 g \\
\hline Miso & 41.45 \\
Edamame & 17.92 \\
Natto & 82.29 \\
Soy cheese ${ }^{2}$ & $6.02-25.72$ \\
Soy four, textured & 172.55 \\
Soy four, defatted & 150.94 \\
Soy lecithin & 15.7 \\
Soy protein concentrate & 94.65 \\
Soy protein concentrate & 11.49 \\
Soy protein isolate & 91.05 \\
Shoyu (soy sauce) & 1.18 \\
Soy beans, roasted & 148.5 \\
Soy beans, raw & 154.53 \\
Yuba / foo jook & 44.67 \\
Soy milk ${ }^{5}$ & $0.7-10.73$ \\
Sufu & 13.75 \\
Tempeh & 3.82 \\
Tofu 6 & $13.1-34.78$ \\
Okara & 9.39 \\
Fuyu & 45.51 \\
Soybean oil & 0
\end{tabular}

${ }^{1}$ From USDA Database for the Isoflavone Content of Selected Foods [64]. ${ }^{2}$ American, Cheddar, Monterey Jack, Mozzarella, Parmesan, Swiss, unspecified. ${ }^{3}$ by aqueous washed. ${ }^{4}$ by alcohol extraction. ${ }^{5}$ Original, from soy isolate, unflavours, flavours, non-fat, low-fat, full fat, fortified, unfortified. ${ }^{6}$ regular, extra firm, firm, silken, soft, yogurt, raw, pressed, steamed, cooked, dried, braised, fried, smoked.

Isoflavones in soy occur mainly in glycoside form, bound to a sugar molecule [33]. Food fermentation during processing or gut digestion breaks glycoside bond by $\beta$-glucosidase enzymes of starter microorganisms used in food transformations or by microbial strains of gut microbiota after ingestion. Breaking of glycoside bond leaves isoflavones in aglycone form [33,136-139]. Dietary habits may have a rapid and strong effect on gut microbiota composition [140,141]. Influence of diet on microbiota is not only limited to fibre, starch, sugar and carbohydrates intake but also involve protein and fat components of foods [142-144]. Aglycones occur mostly in the form of genistein (5,7, $4^{\prime}$-tihydroxylisoflavone), daidzein (7, $4^{\prime}$-dihydoxyisoflavone) and glycitein (7,4'-dihydroxy-6-methoxyisoflavone) in a ratio of 58:37:5, respectively [18].

Malonyl glycoside isoforms are predominant among soy foods [145,146]; however, a minor fraction of isoflavones occurs in aglycone form (especially in fermented products) or acetylglucosides, mainly after thermal treatment $[147,148]$. The isoforms of soy isoflavones and similarity between isoflavones and endogenous oestrogens are shown in Figure 1.<smiles>[R3]c1cc2occ(-c3ccc(O)cc3)c(=O)c2c([R1])c1[R]</smiles>

(a)<smiles>CC12CCC3c4ccc(O)cc4CCC3C1CCC2O</smiles>

(b)

Figure 1. Cont. 


\begin{tabular}{|l|c|c|c|}
\hline Soy Isoflavone & R1 & R2 & R3 \\
\hline Genistein (Aglycone) & $\mathrm{OH}$ & $\mathrm{H}$ & $\mathrm{OH}$ \\
\hline Daidzein (Agrlicone) & $\mathrm{H}$ & $\mathrm{H}$ & $\mathrm{OH}$ \\
\hline Glycitein (Aglicone) & $\mathrm{H}$ & $\mathrm{OCH}_{3}$ & $\mathrm{OH}$ \\
\hline Genistin & $\mathrm{OH}$ & $\mathrm{H}$ & Glucoside $\left(\mathrm{C}_{6} \mathrm{H}_{2} \mathrm{O}_{6}\right)$ \\
\hline Daidzin & $\mathrm{H}$ & $\mathrm{H}$ & Glucoside $\left(\mathrm{C}_{6} \mathrm{H}_{12} \mathrm{O}_{6}\right)$ \\
\hline Glycitin & $\mathrm{H}$ & $\mathrm{OCH}_{3}$ & Glucoside $\left(\mathrm{C}_{6} \mathrm{H}_{12} \mathrm{O}_{6}\right)$ \\
\hline Acetylgenistin & $\mathrm{OH}$ & $\mathrm{H}$ & Acetyl glucoside $\left(\mathrm{C}_{6} \mathrm{H}_{12} \mathrm{O}_{6}-\mathrm{CO}_{-} \mathrm{CH}_{3}\right)$ \\
\hline Acetyldaidzin & $\mathrm{H}$ & $\mathrm{H}$ & Acetyl glucoside $\left(\mathrm{C}_{6} \mathrm{H}_{12} \mathrm{O}_{6}-\mathrm{CO}_{-} \mathrm{CH}_{3}\right)$ \\
\hline Acetylglycitin & $\mathrm{H}$ & $\mathrm{OCH}$ & Acetyl glucoside $\left(\mathrm{C}_{6} \mathrm{H}_{12} \mathrm{O}_{6}-\mathrm{CO}-\mathrm{CH}_{3}\right)$ \\
\hline Malonylgenistin & $\mathrm{OH}$ & $\mathrm{H}$ & Malonyl glucoside $\left(\mathrm{C}_{6} \mathrm{H}_{12} \mathrm{O}_{6}-\mathrm{CO}-\mathrm{CH}_{2}-\mathrm{COOH}\right)$ \\
\hline Malonyldaidzin & $\mathrm{H}$ & $\mathrm{H}$ & Malonyl glucoside $\left(\mathrm{C}_{6} \mathrm{H}_{12} \mathrm{O}_{6}-\mathrm{CO}-\mathrm{CH}_{2}-\mathrm{COOH}\right)$ \\
\hline Malonyldlycitin & $\mathrm{H}$ & $\mathrm{OCH}_{3}$ & Malonyl glucoside $\left(\mathrm{C}_{6} \mathrm{H}_{12} \mathrm{O}_{6}-\mathrm{CO}-\mathrm{CH}_{2}-\mathrm{COOH}\right)$ \\
\hline
\end{tabular}

(c)

Figure 1. Structure similarity between isoflavones and endogenous oestrogens: (a) Isoflavones chemical structure; (b) $17 \beta$-estradiol chemical structure; (c) Residue substitutions in isoflavone structure.

The presence of aglycone form in food matrix could be responsible for isoflavones detectable in plasma after only $30 \mathrm{~min}$ from soy intake and with a peak at $1 \mathrm{~h}$ post-meal [149]. During the first hour of digestion, the hydrolysis of isoflavones takes place in the duodenum and urinary excretion occurs within the first $24 \mathrm{~h}$ after the soy meal [150]. Hydrolysis in aglycone forms allows passive diffusion and absorption in the upper small intestine; conversely, glycosides are poorly absorbed due to their hydrophilicity $[149,151]$. After ingestion, aglycone reaches a peak of plasma concentrations after 4-7 h but it takes $8-11 \mathrm{~h}$ when glycosides form is ingested [152].

It seems that only $50-60 \%$ of Asian people as well as Western individuals among vegetarians can produce 7-Hydroxy-3-(4'-hydroxyphenyl)-chroman (equol) [153-155], a metabolite of daidzein detected in urine after the consumption of soy foods; this suggests an inter-individual capacity in the metabolization of isoflavones that may vary the individual effects [156]. Moreover, only $30 \%$ of the Western population has been shown to excrete equol after soy meals $[154,156]$. Equol formation occurs in the distal intestine and colon [157], indicating that the most of soy isoflavone metabolism takes place in human gut by heterogenic pool of different strains of microorganisms that convert glycoside to equol through the intermediate aglycone $[150,158,159]$. Also intake of other dietary components may influence equol production: diet with high total carbohydrate and low saturated fatty acid has been associated with equol production $[160,161]$ while antibiotic treatments had a negative impact on urine equol excretion [162]. There is a wide inter-individual variation in the pharmacokinetics after soy ingestion of about 15-fold and 12-fold for daidzein and genistein excretion, respectively, with a stronger inter-individual variation up to 600 fold for the equol excretion $[160,163]$. Different ability of producing equol among people could be an important point of interpretation of discrepancies among soy health effects [156]. This conversion takes place in the gut by the microflora $[158,159]$. It is plausible that dietary habits which favour specific microbiota population growth could be critical for the isoflavone absorption and subsequent metabolic action [154]. Moreover, soy contains soluble dietary fibre known to be able to act as prebiotic and so the habit of regular consuming soy foods could enhance ability of producing equol $[69,73,74]$, that can explain the more pronounced competence among soy consumers such as Asian people and vegetarians [155]. In-vitro studies suggest that absorbed genistein and daidzein undergo hydroxylation catalysed by P450 enzymes [164,165]. In a second phase metabolism, isoflavones are conjugates with glucuronic acid or sulphate acid by UDP-glucoronosyl transferase or sulfotransferase enzymes in the liver or in the intestinal epithelium $[166,167]$. The tissue concentration of dietary isoflavones is poorly understood. However, it has been suggested that prostate and breast tissues may have genistein and daidzein concentrations comparable to plasma concentrations, while equol concentration has been shown to be higher [168-171]. 


\subsection{Lipids and Phytosterols}

Soy beans are rich in protein but also in unsaturated fatty acid, especially in linoleic acid, a $\omega 6$ polyunsaturated fatty acid thought to be beneficial for human health [65]. Among other pulses, soy beans are the only legume providing considerable amounts of $\alpha$-linolenic acid, an essential $\omega 3$ fatty acid [76]. Oil matter is composed by $54 \%$ of linoleic acid, $24 \%$ of oleic acid, $11 \%$ of palmitic acid, $1-9 \%$ of $\alpha$-linolenic acid with a total saturated fatty acid fraction of $9-22 \%$ [172-174]. The substitution of foods rich in saturated fatty acid with soy foods showed improvement in cholesterol concentration and reduced the risk for coronary heart disease (CHD) $[175,176]$. Polyunsaturated fatty acid could contribute to the protective effects of soy consumption through the influence on inflammatory parameters [177,178].

Sterols are found in the unsaponifiable matter of soybean fats $[179,180]$. Phytosterols are steroid alcohols with chemical structures similar to animal cholesterol but with some different carbon substituents and saturations in the side chain $[181,182]$. Unlike zoosterols, phytosterols are numerous, of which the most abundant are sitosterol, compesterol and stigmasterol [183]. Compared to the good absorption of cholesterol, phytosterols have been considered as poorly absorbable, as reported using radioactive sitosterol with a retention of $0.6-7.5 \%$ [184]. Cholesterol-lowering effect of soy phytosterols has been reported since 1958 [185] and more recently extensively demonstrated in humans [186-192].

The inability of phytosterols absorption suggested a main luminal intestinal mechanisms of interaction for their beneficial effect but these are poorly understood [188,193]. It seems that for the cholesterol-lowering effect, the concurrent presence of cholesterol and phytosterols in the gut is not required [189]. Recently, human studies also suggest anti-cancer properties and improvements in chronic diseases [194,195]. In a cross-sectional study on an Adventist cohort, mean total phytosterol intake was lowest among non-vegetarians and highest among vegan with no differences in plasma plant sterols and cholesterol [196].

\subsection{Other Bioactive Compounds}

Accumulating evidence have suggested that non-isoflavone compounds in soy beans, such as phytic acid and saponins, display a wide range of bioactivities including antioxidative, antiviral, anticancer, hepatoprotective and cardiovascular protective effects [197]. Moreover, some phytochemicals in soy foods may be in higher concentrations than isoflavones, considering mean composition of $0.1-0.3 \%$ of isoflavones [198], 0,02\% of lignans [199], 1.0-2.2\% of phytic acid [200], $0.23-0.46 \%$ of sterols [181] and $0.17-6.16 \%$ of saponins [201]. It is important to not underestimate the need of established absorption and metabolization of these substances for the achievement of biological effects, depending on food-processing and inter-individual characteristic, especially for the interaction with bile salts in enterohepatic circulation [202]. Future research may focus on the effect on humans of over 100 substances occurring in soy beans, despite the great historical interest for isoflavones [81]. At present, data are scarce and mainly on animals but human interventional studies are needed to understand unresolved mechanisms of action for the soy benefits [81].

Soy protein isolate (SPI) analysis via LC-MS/MS revealed up to 22 saponins [81]. These compounds showed several bioactivities such as protection against cell proliferation and cholesterol reduction $[78,80,203]$. As for isoflavones, soy foods are the primary sources of saponins [204], which naturally take place as different isoforms of glycosides [205]. Soyasapogenols, aglycones of soyasaponins, do not naturally exist in soy beans, although they may occur in soy products after hydrolysis during food processing [76]. Furthermore, cecal microflora hydrolyse soyasaponins with the break of sugar bond [206]. In human studies, metabolites of soy saponins in $24 \mathrm{~h}$ urine collection were not detected but soyapogenols were collected in faecal samples during five days collection, showing that human intestinal microbiota metabolized saponins but with low gut absorbability $[207,208]$. Biological activities of saponins have been summarized in a detailed review [209]. However, it is noteworthy to underline that in vitro possible effects on health may not be replicated in vivo due to the scarce absorption of these compounds. Among the most recognized, 
saponins has been shown to have an effect on serum cholesterol, even though absorption does not take place [210-212]. In fact, insoluble formation of complexes with cholesterol in the intestinal lumen may inhibit reabsorption of bile salts during enterohepatic circulation for the endogenous and exogenous cholesterol reabsorption after soyasaponins intake [213]. Measurements of saponins in soy-based formulas have been investigated only in few studies [214,215].

Lignans are considered as another group of phytoestrogens in pulses, cereals, seeds and soy beans [117,199]. Bioavailability of lignans has been extensively studied in humans but there is no sufficient data on soy lignans [216]. Intestinal bacteria convert plant lignans to enterolignans, known as enterodiol and enterolactone, that are efficiently absorbed [217,218]. Lignans may exert anticancer activity mediated by interaction with oestrogen receptor; however, antiestrogenic and estrogenic activity of enterolignans in humans are still debatable [219].

Phytic acid and its salt phytate, is a polyphosphorylated carbohydrate widely and naturally occurring in plants. Phytate functions as the storage of minerals and in particular phosphorus, containing about 75\% of total phosphorus of the kernel [200]. In soy beans, phytate is the major source of phosphorus but it is also considered a strong chelator for mineral, including calcium, iron and zinc [220]. However, the contribution of phytate antinutrient effect to malnutrition occurs only with high intake of uncooked and unrefined vegetables in association with low micronutrient intake [221].

Instead, soy could be a good source of calcium and iron (see Table 1), which is of major interest in vegetarian nutrition [82]. In the past, iron availability from soy beans may have been underestimated [222]. Moreover, recent findings revaluated the notion of the absorption of inorganic iron in respect to eme-iron, thanks to evidence of a more bioavailable plant ferritin in legumes, including soy beans, that could stimulate future biotechnology approaches [223], even though the presence of plant ferritin in soy beans could be very variable [224].

Plasma concentrations of phytate have been directly linked to the intakes, even if human bioavailability studies are very limited [221]. Although phytate is proposed to provide different human health benefits such as antioxidant activity, immune system enhancing, inhibition of pathological calcification, kidney stone formation inhibition, serum cholesterol-lowering effect and the reduction of pathological platelet activity, cancer prevention has been the most debated [225].

Soy beans are also good sources of calcium thanks to the high bioavailability, as defined with fractional calcium absorption of 0.414 and 0.310 from low and high-phytate soy beans, respectively, compared to 0.377 from cow milk [226].

\section{Health Effects}

Isoflavones and soy proteins are the soy nutrients that aroused the most research interest $[65,67,227,228]$. In 1999 Food and Drug Administration of America (FDA) authorized a health claim about the reduction of coronary heart disease linked to soy protein consumption of at least $6.25 \mathrm{~g}$ per portion with a total of $25 \mathrm{~g}$ per day, that stimulated the interest of food industry for soy [229]. FDA relied on a meta-analysis on the effect of soy protein on serum lipid profile in 38 clinical trials that evidenced a relationship between soy consumption and total cholesterol, LDL and triglyceride blood levels [230]. Afterwards, claims on soy were released in other countries such as Canada, UK, Brazil, Indonesia and Philippines, mostly for $25 \mathrm{~g}$ of soy proteins as intervention for cardiovascular protection [228,231,232]. Vegetarians consuming such quantities of soy were very uncommon; however, cholesterol improvement efficacy of vegetarian diet was established [233]. Moreover, in epidemiological study, lowering effect were achieved with far less soy protein intake than FDA threshold [27,234]. In 2000 the Nutrition Committee of the American Heart Association released a statement for healthcare professionals about soy protection effect against CHD [235]. However, European Food Safety Authority (EFSA) in 2012 stated that cause-effect relationship between isolated soy protein and serum LDL concentration reduction was missing [236]. The beneficial effects on human health depends on both protein and isoflavone content of soy beans, even though the interaction with 
other soy components cannot be excluded. Interestingly, isolate isoflavone seems to have no effect on blood lipid markers in postmenopausal women [237].

Isoflavones can exert health benefits through oestrogen-dependent and independent mechanisms $[238,239]$. Concerns about the adverse effect of soy consumption were originally based on animal data [240-242]. Today we are aware of the difficulty of extrapolating data from in vivo study to human utility in daily application [243]. In murine models, for example, in utero exposition of estradiol were not comparable to humans due to picomolar versus micromolar concentrations, respectively [244]. Monkey differs from human in isoflavone metabolism, with a more efficiency in daidzein to equol conversion [245]. Non-human primates and rodents have a profoundly different isoflavone metabolism [245-251].

In epidemiological studies, Asian traditional diets rich in phytoestrogens were linked to lower risks of coronary heart disease [230,252-254] and there are some evidence on possible benefit in hormone-dependent prostate [255-257], colon, breast [258-262] and ovarian cancers [263-265], menopausal symptoms [266,267], osteoporosis [268-272], obesity [273], cognitive dysfunctions [274] and overall risk reduction for non-communicable diseases $[109,263,264,275]$. Though estrogenic potency of isoflavones was weaker in relation to $17 \beta$-estradiol [276], circulating isoflavone levels may exceed endogenous estradiol concentrations in subjects with diet rich in soy foods [126,277].

The debate on the potential perturbation on sex hormones network by phytoestrogens specially pertains infants fed soy-based formula [81] and the putative consequences of massive introduction early in life $[278,279]$. Moreover, dietary soy intake has been associated with increased risk of thyroid disorders [280], bladder cancer incidence [281], dementia [282] and breast cell proliferation [283,284]. Soy use during pregnancy was shown to alter the epigenome in offspring and can have health implications of in utero stimuli [285].

\subsection{Possible Beneficial Effects}

Epidemiological data showed that isoflavone intake could be responsible for the different CVD rate between Asian and Western countries [264,286,287]. There are possible beneficial effects associated with soy consumption, some of which may depend on its phytoestrogen content. Antioxidative effect of flavonoids may protect from cancer development in which free radicals play a well-known role [123]. In vivo and in vitro studies suggested both estrogenic, antiestrogenic and not hormonally dependent mechanisms of action [288-292]. Furthermore, during the digestion of soy in the gut, the release of biologically active soy peptides, such as conglycinin, takes place. These compounds may have a preventive role in cancer, hypertension, hypercholesterolemia, obesity and oxidative stress [293-296]. Several evidences have been produced to date, suggesting an overall beneficial effect of isoflavones on human health $[297,298]$.

\subsubsection{Cardiovascular and Metabolic Protection}

The first report of soy protein influence on lipid metabolism was published in 1967 [299]. In 38 controlled clinical trials, the intake of an average of $47 \mathrm{~g}$ per day of soy protein showed a 9.3\% reduction in total cholesterol, $12.9 \%$ in LDL and $10.5 \%$ in triglycerides [230]. The substitution of $25 \mathrm{~g}$ of typical Western diet protein with 25 of soy protein reduced LDL by $4 \%$ [300].

In vitro studies have revealed that genistein enhanced activities of antioxidant enzymes such as catalase, glutathione peroxidase and superoxide dismutase [301]. The antioxidant capacity of isoflavones has been shown to be comparable to Vitamin E [135,301,302]. However, isoflavones undergoes extensive metabolism in liver and gut, so antioxidant capacity could be affected [303]. The antioxidant capacity could manifest on LDL. In fact, after 17 days of dietary supplementation of soy protein rich in isoflavones, lag time of LDL oxidation by copper was prolonged [304]. The cholesterol lowering effect of soy has been used as therapy for several decades [305]. A recent rigorous meta-analysis confirmed the increase of high density lipoprotein (HDL)-cholesterol with the reduction of total and LDL-cholesterol in adults with normal or high plasma cholesterol [306]. However, 
the overall effect was weaker than previously reported. A recent meta-analysis of randomized controlled trials of the last 10 years showed significant reduction of serum LDL, triglycerides and total cholesterol concentrations with the increase of HDL concentrations, especially in hypercholesterolemic patients [61]. Stronger effect emerged with whole soy and soy foods compared to soy extracts and with no effect for isoflavone supplementation. Weaker effect in North/South America compared to Europe, Asia and Australia, when stratified by location was observed [61].

Multiple mechanisms are involved and include the action of fibre, protein and isoflavone of soy beans, as well as the intake of soy pectins and the improvement of diet by removing saturated fatty acid sources in place of unsaturated fatty acids from soy [300,307]. Meta-analysis also suggest a modest effect in lowering blood pressure by soy proteins [132,308]. In contrast, only limited evidence on the association between isoflavone intake and risk of hypertension is available [309]. Regarding diabetes, some studies showed a marginal to significant association with risk reduction [310-312], despite one report showed null results [313].

In a recent meta-analysis of observational studies on consumption of soy and risk of CVD, a significant negative association was shown, especially in case-control studies and for Asian people but results were non-significant in geographic stratification analysis for Western studies (The Netherlands, Italy and USA) or in stratification analysis by gender for males [314]. No link has been observed between isoflavone consumption and risk for CVD with a little protective effect with tofu consumption [314]. In an Asian population the consumption of $6 \mathrm{~g}$ or more of soy proteins showed a reduction of ischemic and cerebrovascular evens, as well as total cholesterol and LDL reduction, as showed by prospective observational studies [315].

Soy may improve endothelial function, slowing progression of atherosclerosis in subclinical phase [230,316,317]. Urinary equol has been inversely related with risk of coronary heart disease in women [254]. Mechanistic studies provide a convincing rationale but additional epidemiological studies are needed to strengthen evidence of the protective effect of soy on cardiovascular disease risk factors.

\subsubsection{Anticancer Properties}

The beneficial effect of soy food in the diet of Asian and Western women has been highlighted, even for those with breast cancer diagnosis [318,319]. In a Chinese cohort of 73,223 women with high breast cancer risk, a strongly statistically significance has been showed in a prospective study between soy food intake and reduced risk of premenopausal cancer risk but without any association with post-menopausal breast cancer [320].

Anticancer effects of soy have been largely ascribed to isoflavones, which can modulate cell cycle, apoptosis, differentiation, proliferation and cell signalling [321-324].

An inverse association between soy food intake and breast cancer in Asian population has been reported [325]. Even prostate cancer had a lower incidence rate in Asian population and this phenomenon has been linked to intestinal bacteria competence in daidzein to equol conversion [326]. However, while soy use significantly reduced prostate cancer diagnosis, prostate specific antigen levels in serum (PSA) was not affected by short term soy isoflavone intake [327-331].

Genistein inhibited Human DNA Topoisomerase II enzyme activity in vitro, so in high amount could have an anticancer activity [332]. In breast cancer cell lines phytoestrogens modulated chromatin transcription through epigenetic modifications such as methylation and acetylation of histones [333]. In fact, cancer is characterized by gene expression de-regulation [334]. A protective action during the cancer promotion phase may explain health benefits such as reduced breast cancer risk and reduced recurrence in Asian women exposed to soy since infancy [335].

A recent systematic review and meta-analysis about the association between soy isoflavones consumption on colorectal cancer risk, showed a significant lower relative risk, with statistical significance in pooled analysis for soy foods, Asian populations and case-control studies [336]. 
A systematic review and meta-analysis on association between isoflavones and endometrial cancer show that dietary soy isoflavones from soy beans and soy foods were associated with the reduction of the risk of endometrial cancer (OR: $0.82,95 \%$ CI 0.72 to 0.92 ), with statistical significance in pooled analysis for geographical regions for both Asian (China, Japan) and non-Asian countries (USA, Sweden, Italy, Australia) [337].

It seems plausible that the best advantage in soy food consumption comes from little but frequent intakes over the day of phytoestrogens-rich foods [145].

Risk reduction of breast cancer in case-control studies was associated with higher soy intake, particularly early in life [26,320,338,339].

A recent comprehensive meta-analysis including 143 studies on the association between isoflavone intake and cancer risk distinguished results by study design as only prospective studies are considered valid to draft evidence of association between foods and health outcome: the report showed significant results for the association between isoflavone intake and decreased risk of stomach and lung cancer, while nearly significant decreased risk of breast and colorectal cancer [340]. However, further prospective studies are needed to confirm the latter retrieved association.

\subsubsection{Menopause and Osteoporosis}

Recent studies have pointed out the importance of nutritional factors on gynaecological-related conditions [341,342]. In particular, the link between soy foods and menopause has been shown by clinical and epidemiological data [343,344]. In Western countries the use of phytoestrogen supplements among postmenopausal women was recently increased as an alternative to hormone replacement therapy [345]. In a position statement of 2015, a consensus of soy isoflavones as a first-line approach to vasomotor issues in menopause has been achieved [346]. Grade I of evidence in efficacy of isoflavones on menopausal hot flushes has been declared in a position paper of the International and Austrian Menopause Society [346].

In 2011, a review of literature including Cochrane Library, conducted meta-analysis of randomized controlled trials and found a reduced resorption turnover through bone markers and bone mineral density in menopausal women using soy isoflavones [347].

The reduction of bone mineral density in menopause can be caused by decline in endogenous oestrogens and hormone replacement therapy or soy supplements are able to reduce risk of osteoporosis [18]. Peri-menopausal bone loss was attenuated by consumption of soy protein isolate rich in polyphenols [268]. In a recent randomized crossover trial, soy isoflavones to equol conversion capacity was linked to increased bone calcium content in postmenopausal women [348]. Isoflavones in aglycone form could be crucial for favourable bone effects as revealed by an Italian 3-years intervention study of genistein supplementation with the improvement in bone mineral density [349]. However, some data were inconsistent or with absence of effect in bone formation markers, maybe in part dependent by the usage of isoflavones in glycoside form [350-356]. Clinical studies have failed to show improvements in calcium balance with soy protein intake in comparison to animal protein $[357,358]$. In a prospective epidemiologic study on US Seventh-Day Adventists participants, soymilk or diary consumption were associated with similar degree to significantly lower risk of osteoporosis [359].

There is some evidence on the reduction frequency and severity of hot flushes in post-menopausal women by soy foods $[266,343,360,361]$. Isoflavones intake has been proposed as a safer alternative to hormone treatment in controlling hot flushes [362]. As for other health effects, bioconversion of isoflavones to active metabolites could be crucial for relief from menopausal discomforts [361,363,364].

In addition, soy beans provide high quality protein that could be critical for bone health $[365,366]$. Furthermore, soy beans are rich in calcium that may contribute to the achievement of the post-menopausal women dietary reference intake of $1200 \mathrm{mg}$ per day $[107,367]$. Calcium bioavailability from soy was optimal, despite phytic acid and oxalate acid retention in seeds [226,368]. 


\subsubsection{Other Beneficial Effects}

There are only limited information on body weight loss in human studies [273,369,370]. Soy is thought to alleviate complications of obesity by decreasing lipoprotein lipase activity and ameliorating insulin resistance [369,371,372]. The limited content of carbohydrates and higher content of protein makes soy a good candidate for management of glycaemic response in diabetes and insulin resistance patients and more in general in metabolic diseases [373,374]. High-protein weight-loss diets with meat or soy-based protein sources showed similar appetite control and weight loss among obese men in a randomized crossover trial [375].

Limited data suggested that soy can be beneficial on renal health [376], cognitive functions [377], immunity [378] and reproduction [379].

As mentioned above, intestinal activation of soy phytochemicals by microbiota could be crucial for absorption and efficacy of soy bioactive compounds. Furthermore, soy itself can shape gut microbiota [380,381]. Soy and soy foods can provide substrates useful in modulating the growth of specific bacterial strains [382]. Soy-based drinks, widely used in Western and Asian countries, can provide polysaccharide and proteinaceous compounds, easily fermentable by gut microbial populations [383-386]. Influences on gut microbiota could be partially linked to the beneficial effects of soy on metabolic syndrome.

Intakes of $500 \mathrm{~mL}$ of soy-based drink in obese or overweight men seemed to change main gut microbial phyla by stimulation of Bacterioidetes and Proteobacteria growth and reduction in relative abundance of Bifidobatera and Firmicutes. Different formulation in protein content can stimulate differential bacterial growth [380]. However, replacement of cow milk-based formula with soy-based formula in feeding infants 3-8 months old, stimulated no variation in selected Bifidobacteria species [387]. Isoflavones are naturally produced by plants as chemical defence from fungal and bacterial infection and, therefore, may provide a contribution in shaping of gut microbiota through antimicrobial activity $[388,389]$. Also saponins could have a concerted effect with isoflavones on simulation of microbial population that could modulate isoflavone activation by stimulating equol producing bacteria [381,390]. Therefore, it is plausible that isoflavones efficacy depends on inter-individual bioactivation capacity but, at the same time, the presence of soy phytochemicals and isoflavones in gut lumen may act on microbiota activation competence, thereby promoting absorption and efficacy of soy components itself. Traditional production of soy foods, including different fermentation procedures, imply the occurrence of new bioactive chemical substances in food matrix that are relevant in shaping of microbiota (see also section below of soy foods transformation) [391]. The health-promoting effects of fermented soy foods have been shown in different disease [392-394]. Unfortunately, most of the data came from animal studies, which are very hard to transfer into human physiology [395-402].

\subsection{Possible Detrimental Effects}

\subsubsection{Thyroid Gland Disturbance}

In vivo studies on thyroid functions have raised some concerns about perturbation effects of soy in people with clinical or subclinical thyroid diseases [403,404]. However, it is unlikely that soy foods can alter thyroid function in euthyroid individuals even in iodiopenic circumstances [405-407]. In vitro inhibition of thyroperoxidase activity was not followed by disturbance of thyroid gland metabolism in people consuming foods rich in flavonoids, even with the intake of isolated genistein in post-menopausal women [408]. In a cross-sectional epidemiological study on North American churchgoers belonging to the Seventh-Day Adventist church, a significant positive association between soy intake and thyroid-stimulating hormone (TSH) in women but not in men was found [409]. Though, the relatively low intake of iodine in the cohort can partially explain the thyroid susceptibility to soy. Soy flour based infant formula was linked to goitre before iodine fortification [410-412]. In vitro studies showed an inhibitory effect of soy isoflavones in aglycone form on thyroxine synthesis by 
thyroidal gland only in absence of iodine [280]. Goitres observed in infant fed with soy-based formula were reversed with iodine fortification [408]. Even if hypothyroidism characteristic is the slow growth, this phenomenon was not seen in infants fed with soy formula. More long term epidemiological studies are needed to verify soy-thyroid interaction in real conditions and to discriminate from clinical trials, which often use isolated isoflavones with a wide range of concentrations and heterogenic conditions [413].

In light of the inhibition effect of soy foods on the absorption of thyroid hormone replacement therapy, it has been suggested that hypothyroid patients should outdistance drug intake from soy consumption and more in general from any food rich in fibres and phytochemicals [414,415].

\subsubsection{Sex Hormones Perturbation}

The action of phytoestrogens as selective oestrogen receptor modulators, makes it unlikely to have negative effects in oestrogen pathways. Perturbation of sex hormone network and infertility issues attributed to soy foods are in strong contrast with that found in large populations of soy-consuming countries. The link between soy and reproduction has been postulated in 1940 after recognition of endocrine disruption by isoflavones of red clover in pasture given to ewe flocks, resulting in infertility syndrome called "clover disease" [416]. In 1976 Shutt speculated a defence action of some plants with antifertility factors for mammalian predators [417].

Little perturbation on reproductive health have been reported, including feminizing effects, erectile dysfunction and reduced libido linked to very large intakes of isoflavones, even though available data revealed only minor detrimental effects or no impact on health [418,419]. However, no oestrogen perturbations were reported in clinical studies with high exposures to isoflavones in men [420]. In a cross-sectional study, soy foods intake was inversely linked to sperm concentration in 99 men despite no changes in quality parameters and the cohort was enrolled from sub fertile couples group with no detailed information on soy intakes [421]. Conversely, sperm count and motility were positively related to isoflavone intake [422] or with no correlation between isoflavone intake and sexual hormones or semen quality [423]. Testosterone levels were evaluated in a meta-analysis of 32 reports with no conclusive interaction between soy or isoflavone intake and free testosterone concentrations [424]. The majority of information about soy to sex hormones interaction came from in vitro and in vivo studies [379,425].

Regarding reproductive health in women, a cross-sectional study of 11,688 women aged 30-50 years of North American Adventist church showed that high intake of isoflavones was related to increased risk of nulliparity and nulligravity [426]. The effect on pregnancy was observed for intake $\geq 40 \mathrm{mg}$ per day. A systematic review of literature showed that effect of soy on sex hormones in preand post-menopausal women had very small effect, as well as on thyroid function in post-menopausal women [133].

Soy-based formula is commonly used in Western countries for allergy to cow milk proteins or as alternative vegetarian choice $[427,428]$. Urinary total isoflavones among infants fed with soy formula were 500 times more concentrated compared to cow milk formula fed infants [429]. Even plasma isoflavone concentrations were 10 times more concentrated in soy formula fed infants [430].

In a longitudinal epidemiological study, introduction of soy products into infant diet before 4 months of age was associated with a $25 \%$ higher risk of menarche before 12 years of age, in support of mild endocrine disrupting effects of soy isoflavone exposure [431]. However, these preliminary findings did not report the exact amount of soy intake in the sample so it was not possible to assess a true dose-response relationship. A retrospective epidemiological study did not find a link between exposure to soy formula and reproductive outcomes [432]. In a cross-sectional study on Seventh-day Adventist girls with age ranged between 12 and 18 years, no correlation between soy intake and the age of menarche was found [433]. 


\subsubsection{Procancer Activity}

Like many other potential detrimental effects, concerns about the interaction between intake of isoflavones from soy and neoplastic events came mainly from in vitro and animal model studies [434-437].

In the European Prospective Investigation into Cancer and Nutrition Study cohort (EPIC) there were no increase in cancer risk caused by soy isoflavone intake [438].

In 2010 a meta-analysis found no effects on postmenopausal women by isoflavone intake, assessed with mammographic density [439]. Similarly, a blinded randomized clinical trial found no variation in breast MRI fibroglandular tissue density or mammographic density in women with breast cancer and at-risk women with 1 year soy intake intervention [440].

Overall, epidemiologic studies support a protective role of soy foods in breast cancer, as confirmed by meta-analysis of cohort and case-control studies in Asian and Western countries, with preand post-menopausal women and with a more protective effect in Asian Women [441]. A large prospective epidemiologic studies showed that soy intake after diagnosis of breast cancer favourably affected prognosis [318]. British women in the EPIC-Oxford arm, which oversampled vegetarians, had isoflavone intake similar to Asian people in epidemiologic studies. Nevertheless, high-soy consumption in this cohort was unrelated to breast cancer risk, possibly due to adoption of dietary habit only in adult age and with low soy consumption in infancy [442]. The "early-intake" hypothesis could explain discrepancies in epidemiologic data from different countries [443].

\section{Soy Foods}

There are several soy foods, traditional Asian foods (fermented or not) and new generation products, such as soy milk, edamame, tofu, soy cheese, miso, soy sauce (tamari, shoyu), tempeh, natto, sufu, yuba, soy flour, soy protein isolated (SPI) and meat analogues also called Textured Vegetable Protein (TVP). Table 7 shows a description of selected soy foods.

Table 7. Soy foods description ${ }^{1}$.

\begin{tabular}{cl}
\hline Item & \multicolumn{1}{c}{ Description } \\
\hline Tofu & $\begin{array}{l}\text { Soaking and heating procedures with addition of protein coagulants such as calcium } \\
\text { sulphate to soymilk. Pressed soy curd can undergo smoking or marinating processes. }\end{array}$ \\
\hline Soy milk & $\begin{array}{l}\text { Water extraction of hulled and crushed soy beans. Boiling after filtration of raw milk } \\
\text { removes beany flavour. }\end{array}$ \\
\hline Tempeh & Dehulled soy beans fermented with Rhizopius oligosporus. \\
\hline Natto & Soy beans fermented with Bacillus natto and Bacillus subtilis. \\
\hline Sufu & Tofu fermented with Actinomucor elegans. \\
\hline Edamame & Immature, green soy beans. \\
\hline Miso & Fermented soy beans with Aspergillus orzae or Aspergillus soyae. \\
\hline Yuba & Drying of skin (film) formed in soymilk production during boiling. \\
\hline Soy Sauce & $\begin{array}{l}\text { Soy beans or soy flakes fermented with different bacteria, yeast or treated with isolated } \\
\text { enzymes. Pressing and filtration after fermentation is needed to extract aqueous phase. }\end{array}$ \\
\hline Textured vegetable protein & $\begin{array}{l}\text { Extrusion and cooking of soy flour, full fat or defatted, in moisture and temperature } \\
\text { controlled conditions. }\end{array}$ \\
\hline
\end{tabular}

In European countries, there is a wide variation of soy foods consumption. In Germany, Spain and The Netherlands, most frequently consumed has been reported to be beans and sprouts. In Italy, grain products were the most frequently consumed soy foods. In Denmark, soy meat substitutes were the most popular, instead; in the UK soy dairy substitutes were the main soy-based food consumed [43]. TVP provides a good source of protein in the form of soy meat analogues, readily digestible. In fact, protein digestibility was $66.1 \%$ and $63.4 \%$ for TVP defatted soy four and TVP protein concentrate, respectively, in comparison to $73.2 \%$ for beef [444]. 
Food processing can dramatically perturb the composition of soy products by altering nutrient and antinutrient content; moreover, artificial compounds from processing may also occur $[445,446]$. For example, processing of soy beans may improve nutritional quality by the reduction of antinutrient naturally present in foods but Maillard reactions may reduce amino acid bioavailability $[447,448]$. Heat induced interaction between amino acids and sugars results in the formation of Amadori's compounds of Maillard reaction consisting in browning products and acrylamide [449]. Highly processed soy foods can lose up to $80 \%$ of their isoflavone content [33].

Numerous aromatic compounds were isolated from miso and soy sauce [450,451]. Furthermore, a 1.7 fold increase in folate content was reported after soy bean fermentation in tempeh [452]. The fermentation process of soy foods not only affects sensory properties and shelf life but also changes in nutritional value and digestibility may occur [453]. Noteworthy, food processing may influence the final phytoestrogen content [454]. Also starter microorganisms used for fermentation could give additional beneficial human health properties such as probiotic functions [455].

In countries of European Union, definition of milk is "substances secreted from mammary gland" [456]. For non-compliance reasons, "soy milk" definition is not permitted for sale.

Even though soy based formula was often used for infants with atopic disease, $10-14 \%$ of subjects with a diagnosis of cow milk allergy were also positive for the soy allergy [427,457-459]. Soy based formula is preferred by parents with vegetarian lifestyle [427].

Soy-based drink full-fat contains about $24 \%$ of calories from protein (mainly glycinin and conglycinin), $45 \%$ from carbohydrate, with absorbable and not absorbable mono and polysaccharides, including fructose, glucose, galactose, sucrose, stachyose, raffinose and others and $31 \%$ of calories from oil $[385,386]$.

Soy beans, SPI, tofu, soy milk and fermented food products such as miso, natto, tempeh and soy sauce are the most considerable dietary source of isoflavones in human nutrition [460,461]. Different processing method could be responsible for isoflavone isoforms content in soy-based formulas [214].

In soy flour, total isoflavone concentrations range from 60 to $265 \mathrm{mg}$ per $100 \mathrm{~g}$, tofu may contain between 5.1 and $64 \mathrm{mg}$ per $100 \mathrm{~g}$ of total isoflavones, soy milk 1.3-21 mg per $100 \mathrm{~g}$, tempeh 6.9-63 mg per $100 \mathrm{~g}$, soy sauce $0.1-2.3 \mathrm{mg}$ per $100 \mathrm{~g}$ [64], miso 23-126 mg per $100 \mathrm{~g}$ [64,462] and natto 20-124 mg per $100 \mathrm{~g}[463,464]$.

Deep-frying of tempeh reduced isoflavone content by almost $45 \%$ [465]. Temperature is critical for retention of isoflavones: in fact, soymilk film formed during boiling, called Foo joke or Yuba, has been reported to have $196.05 \mathrm{mg}$ per $100 \mathrm{~g}$ of isoflavone compared to $44.67 \mathrm{mg}$ per $100 \mathrm{~g}$ after cooking [64]. Also soaking temperature and time in edamame production (immature soybean seeds), contributes to isoflavone variation [466].

Bioavailability of isoflavone isoforms is still a debate. Soy drinks and TPV contain predominantly glycoside compounds, while tempeh, miso, natto and fermented soy milk (including sufu) contain aglycone forms. Aglycones are more readily absorbed than glycosides and liquid matrix enhances absorbability compared to solid foods [467-470].

\section{New Generation Foods}

The nutritional value of soy foods obtained from SPI could be lower than unprocessed or minimally processed foods [471]. Frequently, meat analogues are prepared by extrusion with different moisture conditions, which confer meaty consistency, much more acceptable for consumers, thanks to re-texturization through formation of disulphide bonds $[472,473]$. Change in molecular structure through formation of disulphide bonds plays a critical role in texturizing of soy fibrous protein in meat analogues [474]. However, non-covalent interactions and disulphide bonds formation during cooking and extrusion may lead to changes in the quality of proteins and nutritional value of products through Maillard reaction, gelatinization and autoxidation [444,475]. Studies which have investigated the worsening of nutritional characteristics of extruded products were carried out under low or moderate moisture conditions. On the contrary, working at high moisture and low temperature during extrusion 
process could be useful to preserve nutritional value [472,473]. Sometimes, digestibility of texturized soy foods has been found to be higher than unmodified proteins [476]. No differences in isoflavone patterns between unextruded and extruded soy meals were observed but bioavailability was not be tested [477].

Meat analogues have higher polyunsaturated fatty acids, potassium, calcium and phosphorous compared to ground beef, with no alteration of amino acid profile and biological value after home cooking [478]. New generation soy foods resulted from recent advances in improving taste characteristics through plant breeding and new processing technologies [479,480].

Soybean oil is widely produced and consumed as cooking oil worldwide [481]. Soy oil have negligible amounts of isoflavones because it is often obtained by alcohol extraction, which is the same procedure used for soy defatting. Aqueous extraction can obtain high isoflavone concentrations due to the hydrophilicity of soy isoflavones [15]; these compounds are tightly associated with proteinaceous matter and food processing such as alcohol extraction significantly decreases phytochemicals content [371].

Variability of isoflavone content was detected in vegetarian food alternatives [482]. The most refined soy foods can lose up to $80-90 \%$ of isoflavone content during processing $[33,483,484]$. Soy burgers have $0.1-26 \mathrm{mg}$ per $100 \mathrm{~g}$ of total aglycone equivalents, soy yogurts $1.6-11.8 \mathrm{mg}$ per $100 \mathrm{~g}[22,485,486]$, soy drinks 1.0-21 mg per $100 \mathrm{~g}[64,485]$ and soy cheeses 2.3-33 mg per $100 \mathrm{~g}[22,486,487]$. Usually, bakery soy-based products retain low concentration of isoflavones $[64,486,488,489]$. Soy milk formulas may contain up to $31 \mathrm{mg}$ per $100 \mathrm{~g}$ [64].

Overall, the low concentration of isoflavones does not qualify the new generation soy foods as good sources of phytoestrogens, effective for the reduction of chronic disease risks, nor for alleged detrimental effects for soy intake [490]. However, aqueous extraction method used for SPI production could enhance aglycone retention due to $\beta$-glucosidase activity resulting from processing below $50{ }^{\circ} \mathrm{C}$ [454]. Differences in isoflavone content may depend on distribution of isoflavone forms, instead of absolute content, as isoflavones seemed to be very stable at different temperature and pH values $[445,454,491]$. Even so, processing may affect nutraceutical values of soy and soy foods by altering retention and distribution of bioactive substances such as isoflavones [22,492-494].

Interconversion among different isoflavone isoforms could explain the heterogeneity in phytoestrogenic efficacy from various soy foods [495,496]. Indeed, thermal processing decreased malonyl glucosides and increase $\beta$-glucosides and aglycones [497]. Deeply processed soy foods could have very limited concentration of isoflavones due to solvent extraction that limits phytochemicals retention $[371,446,454]$. Conversely, soaking and fermentation processes, typical of traditional Asian soy foods such as tempeh, soy sauce, miso, natto and traditional tofu, could help bioavailability of isoflavones thanks to the increasing of aglycone form concentrations [461,466-470].

\section{Food Safety}

The use of soy in Japanese and Chinese diets has a traditional usage history of safety that was recently extended to Western countries [121]. However, some studies raised concerns regarding soy foods use, such as tofu, on cognitive outcomes [282,498,499]. In a short term dietary intervention study, high soy diet versus low soy diet have no adverse effect on cognitive function and mood in healthy young students [500]. Achievement of some level of college education was non different between soy or cow milk formula fed in infancy [432].

Daily administration of $54 \mathrm{mg}$ of genistein in aglycone form to menopausal women for 3 years did not affect thyroid function [406]. Moreover, $200 \mathrm{mg}$ of isoflavones daily administration for 2 years did not influence TSH [501]. Isoflavones showed an overall good profile of safety for thyroid function [413].

In 2015 an EFSA panel concluded that the intake of 35-150 mg per day of isoflavones from supplements or foods does not have adverse effect on sex hormones-responsive tissues such as breast and uterus or thyroidal gland up to 2.5 years duration of intake [502]. 
Clinical and prospective epidemiological data show safety of use during isoflavone exposure in women [503,504]. In a double blind randomized intervention study of 12 months, soy intake did not worsen breast fibroglandular tissue density in breast cancer patients previously exposed to antineoplastic treatments or in women at high risk [440]. Moreover, exposure to isoflavones or soy protein in breast cancer patients was associated with reduced mortality and cancer recurrence in women with $\mathrm{ER}(+)$ and $\mathrm{ER}(-)$ breast cancers [318,349]. No contraindication for isoflavone intake in women under treatment with tamoxifen or anastrozole has been observed [505-507], rather, soy consumption enhanced efficacy of anticancer treatments [508,509].

\subsection{The Early Stage of Infant Nutrition}

Infant feeding with soy-based formulas could be a leading cause of concerns for soy use. Early and massive exposure to soy bean bioactive compounds, concurrently with low body weight, raised doubts about the perturbing influences in sensitive time windows of development during infancy. Soy formula was used worldwide over 60 years to feed millions of infants with no observable adverse effects [427]. First soy-based infant formula was reported over 100 years ago [510]. In the past, Italian infants fed with soy flour based formulas had a poor response to polio vaccine [511-513]. However, modern soy formulas showed good immunodevelopment response to anti-polio [514]. Limitations of soy formula based on soy flour gave rise to SPI formulas with a better nutritional profile in PDCAAS and reduced non protein ingredients such as protease inhibitors, fibres and phytate [515]. In the National Health and Nutrition Examination Survey 2003-2010 (NAHNES 2003-2010), among infants 0 to 12 years old consuming formulas or milk, $12 \%$ were fed with soy formula [516]. Even though it must be stated that human milk is the best nutrition choice for infants [517], in USA and in European Union Countries, infant soy formula SPI based are considered as safe as cow milk based infant formula [515,518]. This statement is not universally shared: in fact, Australian College of Paediatrics claimed that soy based formula is not equivalent to milk formula in micro and macronutrients and infants fed with soy formula need more energy [519]. EFSA released formulation guides for infant formulas, including soy formula, in relation to the needs of infants [518]. Despite the possibility that phytates content of soy-based formula may inhibit micronutrients absorption, no difference was observed in growth and micronutrients status, including iron, of children fed with soy formula compared to cow milk formula $[432,515,520-522]$. Moreover, bone mineralization was at least equal to infants fed with cow milk formula or human milk [523-525]. Even if circulating plasma isoflavones were from 13,000 to 22,000 times higher than estradiol in early life of soy-fed infants [430], plasma isoflavones do not seem to be linked with oestrogen status [526]. However, $99 \%$ of circulating isoflavones exists as sulphate or glucuronide conjugated forms in biologically inactive state, as results of first-pass metabolism via gastrointestinal absorption and liver metabolism [527]. No long term effects on sexual development and maturation have been shown in soy formula fed infants [432,528]. Moreover, soy infant formula milk may promote bone development and support normal growth [529-532]. Early exposure to soy formula and soy foods may provide health benefits in body composition and in prevention of some cancers [531-533].

Inter-individual absorption and metabolization processes of soy bioactive substances are still poorly understood. No difference in absorption and metabolization rates was found after measurement of daily urinary isoflavones excretion of 2-16 weeks old infants in relation to adult samplings [534]. Conversely, another study found that infant absorption under 4 months old was negligible, probably due to the gut microbiota unable to process isoflavones [535]. Additional evidence showed that a $20 \mathrm{~g}$ roasted soy beans intake by lactating woman, significantly increased isoflavone detection in breast milk [536]. A controlled randomized interventional pilot study showed that term breast milk of 18 mothers consuming $250 \mathrm{~mL}$ soy drink with $12 \mathrm{mg}$ of isoflavones, contained about $3 \mu \mathrm{g}$ of isoflavones per litre [537]. One serving of soy beverage intake for 2-4 days increased 10-15 times breast milk isoflavone content in lactating women [538]. These quantities were lower than the concentrations of isoflavones found in soy formulas but it should be investigated if the intake through mammary 
gland secretion after paracellular transport into the alveoli could provide a more bioavailable form of isoflavones.

\subsection{Soy Allergy}

Soy, milk, peanuts, wheat and eggs account for about $90 \%$ of allergy in atopic children, with the latter the most frequent and severe [539,540]. Even though studies with clinically confirmed investigation are scarce, prevalence of soy allergy appears to be low with rare anaphylaxis reactions to soy containing foods.

Frequently soy formulas were prescribed for adverse reaction to cow milk, however, a soybean glycinin protein of $30 \mathrm{kDa}$ cross-reacts with casein [541]. Enterocolitis and other clinical manifestations of soy allergy are overlapping to those of cow milk allergy [542].

Self-reported soy allergy in USA ranged between $0.1 \%$ and $2.7 \%$, with higher prevalence among children up to three years old [543-545]. In Europe, the highest prevalence (1.2\%) was reported among Swedish children of four to eight years old $[546,547]$. Generally, self-reported allergy at all ages in other countries of Europe were $\leq 0.6 \%$ [548-552].

Fermentation of soybeans and soy foods reduces allergenicity, showing very low immunoreactivity of yogurt followed by miso and tempeh [553] but not for soy sauce [554].

Soy allergy does not seem to be an issue in human nutrition, even in infant, taking into account the highest prevalence in children of self-reported cow milk allergy of $10.8 \%$ in Iceland [551] and with the lowest of $1.3 \%$ in Norway [555]. Moreover, the most recent approach to infant nutrition contemplates to not delaying the introduction of any food beyond 6 months of age, even though potential allergenic, to prevent allergy [556], also from peanuts, which causes the most severe food allergy [557].

\section{Conclusions}

Soy consumers are generally driven to find alternative protein sources from animal ones because of a vegetarian style adoption [53]; however, concerns for soy safety in breast cancer and thyroid influence have been reported [558].

The adoption of vegetarian diets has increased over the last decades together with the availability of soy surrogates from grocery stores. The acceptance of milk and meat analogues have already aroused the development of alternative production processes to obtain more safe and nutritionally adequate products [559]. Acceptance of vegetarian options by middle school students seems to pose no complications in substitution of meat based meals with soy-based ones and could facilitate the meeting of saturated fat limit intake in school meals [560-562].

Inter-individual variation of isoflavone activation capacity (mainly located in to the microbiota), differences in cultivar, environmental factor, culture methods, storage, food processing and other confounders (i.e., other dietary habits), pose challenges to forecast the bioavailability and pharmacokinetics of phytoestrogens $[121,563,564]$. It should be noted that the composition of soy food may differ substantially from unprocessed soy beans. More data on safety are needed but soy foods seems to have a favourable effect on women health, in particular if gut daidzein to equol conversion readily occurs [565]. Soy food can be safe and even beneficial if consumed by women with breast cancer diagnosis [566-568]. Among soy products there are remarkable differences in nutrients and phytochemicals composition that need careful interpretation of data on soy effect from different soy foods [569].

Sex hormone network and thyroid gland perturbation seems to be unlikely, especially with low isoflavone intakes actually reported in vegetarian. Overall, the low content of bioactive compounds in second generation soy foods and moderate amounts in traditional soy preparations offer modest health benefits with very limited risk for potential adverse health effects [570]. At the same time, to have the beneficial effects of soy isoflavones, intake should be at least of 60-100 mg per day [571], at present not easily reached in Western countries. 
The "early intake" hypothesis for soy could explain discrepancies in epidemiological data on soy consumption and benefit for human health, especially in breast cancer risk reduction [572]. However, soy and soy food intakes are growing in Western countries, with particular contribution of vegetarians who could harvest the soy benefits. The labelling of soy foods with isoflavones concentrations could be a helpful information for consumer, along with shared guidelines for soy intake in order to obtain health benefits and with the warnings for upper level of intake, especially for long term consumption.

In addition, more clinical trials on other soy bioactive substances could clarify single components/phytocomplex efficacy and safety, even if many of these compounds are recurring in other vegetal of the same botanical family [573].

Despite the high intakes in Asian countries, there is still a paucity of long term data on soy consumption in Western countries. Currently, the use of soy foods in infancy, including soy-based infant formulas, was not linked to adverse events. However, absence of evidence is not an evidence of absence. With the growing adoption of vegetarian diets and with the choice of soy formulas by Western vegetarian parents, a broader characterization of the role of soy foods in Western nutrition could help the acceptance of plant-based new generation foods.

The transfer of data from in vitro and animal model to human health, as well as clinical trial results with isolate or concentrate fractions from soy [574], as well diverse nutraceuticals supplements [575-582], must be carefully interpreted. The disturbing effect of soy on thyroid hormones in subclinical hypothyroidism has been debated but it seems to be a mere goitrogenic mechanism, so it is crucial to satisfy adequate intakes of iodine from foods or by fortification, especially in vegetarians [583-589]. On the other hand, there are other promising foods, such as lupins, mushrooms or single cell proteins (often mycoproteins), as candidates for meat substitutes production. The use of various protein sources could be useful for avoiding a monochromatic nutrition in vegetarians, widely based on soy [13]. Key nutrients in soy (such as proteins, minerals, vitamins and phytochemicals) are also shared by others plant foods, so it is unnecessary in vegetarian diet to always choose soy and soy foods. Seeds, nuts, cereals and other pulses can be good sources of protein that can be alternatively chosen to obtain a nutritionally adequate and healthy diet, as proposed in VegPlate method [590] and the use of soy can be limited to personal taste and habits.

Acknowledgments: There was no funding support for this article.

Conflicts of Interest: The authors declare no conflict of interest.

\section{Abbreviations}

$\begin{array}{ll}\text { ADA } & \text { American Dietetic Association } \\ \text { APP } & \text { alternate protein product } \\ \text { BV } & \text { biological value } \\ \text { CHD } & \text { coronary heart disease } \\ \text { CVD } & \text { cardiovascular disease } \\ \text { DIAAS } & \text { digestible indispensable amino acid score } \\ \text { EFSA } & \text { European Food Safety Authority } \\ \text { EPIC } & \text { European Prospective Investigation into Cancer and Nutrition } \\ \text { ER } & \text { oestrogen receptor } \\ \text { FAO } & \text { Food and Agriculture Organization } \\ \text { FDA } & \text { Food and Drug Administration } \\ \text { GMO } & \text { genetically modified organism } \\ \text { HDL } & \text { high density lipoprotein } \\ \text { HHL } & \text { health-conscious lifestyle } \\ \text { LC-MS/MS } & \text { liquid chromatography tandem-mass spectrometry } \\ \text { LDL } & \text { low density lipoprotein } \\ \text { MRI } & \text { magnetic resonance imaging } \\ \text { NAHANES } & \text { National Health and Nutrition Examination Survey }\end{array}$




$\begin{array}{ll}\text { NPU } & \text { net protein utilization } \\ \text { OR } & \text { odds ratio } \\ \text { PDCAAS } & \text { protein digestibility corrected for amino acid score } \\ \text { PER } & \text { protein efficiency ratio } \\ \text { PSA } & \text { prostate specific antigen } \\ \text { PUFA } & \text { polyunsaturated fatty acids } \\ \text { SERM } & \text { selective oestrogen receptor modulator } \\ \text { SPI } & \text { soy protein isolate } \\ \text { STEAR } & \text { selective tissue estrogenic activity } \\ \text { TSH } & \text { thyroid-stimulating hormone } \\ \text { TVP } & \text { textured vegetable protein } \\ \text { USDA } & \text { United States Department of Agriculture } \\ \text { WHO } & \text { World Health Organization } \\ w / w & \text { weight per weight }\end{array}$

\section{References}

1. Key, T.J.; Davey, G.K.; Appleby, P.N. Health benefits of a vegetarian diet. Proc. Nutr. Soc. 1999, 58, 271-275. [CrossRef] [PubMed]

2. Larsson, S.C.; Wolk, A. Meat consumption and risk of colorectal cancer: A meta-analysis of prospective studies. Int. J. Cancer 2006, 119, 2657-2664. [CrossRef] [PubMed]

3. Rizzo, G.; Baroni, L. Health and ecological implications of fish consumption: A deeper insight. Mediterr. J. Nutr. Metab. 2016, 9, 7-22. [CrossRef]

4. Rizzo, G.; Laganà, A.S.; Rapisarda, A.M.C.; La Ferrera, G.M.G.; Buscema, M.; Rossetti, P.; Nigro, A.; Muscia, V.; Valenti, G.; Sapia, F.; et al. Vitamin B12 among Vegetarians: Status, Assessment and Supplementation. Nutrients 2016, 8, 767. [CrossRef] [PubMed]

5. Young, V.R.; Pellett, P.L. Plant proteins in relation to human protein and amino acid nutrition. Am. J. Clin. Nutr. 1994, 59, 1203S-1212S. [PubMed]

6. Mangels, A.R.; Messina, V. Considerations in planning vegan diets: Infants. J. Am. Diet. Assoc. 2001, 101, 670-677. [CrossRef]

7. Messina, V.; Mangels, A.R. Considerations in planning vegan diets: Children. J. Am. Diet. Assoc. 2001, 101, 661-669. [CrossRef]

8. World Health Organization; Food and Agriculture Organization of the United Nations; United Nations University. Joint WHO/FAO/UNU Expert Consultation. Protein and Amino Acid Requirements in Human Nutrition; World Health Organ: Geneva, Switzerland, 2007; pp. 1-265.

9. Imura, K.; Okada, A. Amino acid metabolism in pediatric patients. Nutrition 1998, 14, 143-148. [CrossRef]

10. Hoffman, J.R.; Falvo, M.J. Protein-Which is Best? J. Sports Sci. Med. 2004, 3, 118-130. [PubMed]

11. Richter, C.K.; Skulas-Ray, A.C.; Champagne, C.M.; Kris-Etherton, P.M. Plant Protein and Animal Proteins: Do They Differentially Affect Cardiovascular Disease Risk? Adv. Nutr. Int. Rev. J. 2015, 6, 712-728. [CrossRef] [PubMed]

12. Marventano, S.; Izquierdo Pulido, M.; Sánchez-González, C.; Godos, J.; Speciani, A.; Galvano, F.; Grosso, G. Legume consumption and CVD risk: A systematic review and meta-analysis. Public Health Nutr. 2017, 20, 245-254. [CrossRef] [PubMed]

13. Kumar, P.; Chatli, M.K.; Mehta, N.; Singh, P.; Malav, O.P.; Verma, A.K. Meat analogues: Health promising sustainable meat substitutes. Crit. Rev. Food Sci. Nutr. 2017, 57, 923-932. [CrossRef] [PubMed]

14. Morr, C.V.; Ha, E.Y.W. Off-flavors of whey protein concentrates: A literature review. Int. Dairy J. 1991, 1, 1-11. [CrossRef]

15. US Department of Agricolture (USDA). Food Composition Databases Show Foods List. Available online: https:/ / ndb.nal.usda.gov/ndb/search/list (accessed on 7 September 2017).

16. Gerber, P.J.; Steinfeld, H.; Henderson, B.; Mottet, A.; Opio, C.; Dijkman, J.; Falcucci, A.; Tempio, G. Tackling Climate Change through Livestock: A Global Assessment of Emissions and Mitigation Opportunities; Gerber, P.J., Food and Agriculture Organization of the United Nations, Eds.; Food and Agriculture Organization of The United Nations: Rome, Italy, 2013; ISBN 978-92-5-107920-1. 
17. Ko, K.-P. Isoflavones: Chemistry, analysis, functions and effects on health and cancer. Asian Pac. J. Cancer Prev. 2014, 15, 7001-7010. [CrossRef] [PubMed]

18. Zaheer, K.; Humayoun Akhtar, M. An updated review of dietary isoflavones: Nutrition, processing, bioavailability and impacts on human health. Crit. Rev. Food Sci. Nutr. 2017, 57, 1280-1293. [CrossRef] [PubMed]

19. Fitzpatrick, L.A. Soy isoflavones: Hope or hype? Maturitas 2008, 61, 132-140. [CrossRef] [PubMed]

20. Munro, I.C.; Harwood, M.; Hlywka, J.J.; Stephen, A.M.; Doull, J.; Flamm, W.G.; Adlercreutz, H. Soy isoflavones: A safety review. Nutr. Rev. 2003, 61, 1-33. [CrossRef] [PubMed]

21. Wuttke, W.; Jarry, H.; Seidlová-Wuttke, D. Isoflavones-Safe food additives or dangerous drugs? Ageing Res. Rev. 2007, 6, 150-188. [CrossRef] [PubMed]

22. Mortensen, A.; Kulling, S.E.; Schwartz, H.; Rowland, I.; Ruefer, C.E.; Rimbach, G.; Cassidy, A.; Magee, P.; Millar, J.; Hall, W.L.; et al. Analytical and compositional aspects of isoflavones in food and their biological effects. Mol. Nutr. Food Res. 2009, 53, S266-S309. [CrossRef] [PubMed]

23. Chen, Z.; Zheng, W.; Custer, L.J.; Dai, Q.; Shu, X.O.; Jin, F.; Franke, A.A. Usual dietary consumption of soy foods and its correlation with the excretion rate of isoflavonoids in overnight urine samples among Chinese women in Shanghai. Nutr. Cancer 1999, 33, 82-87. [CrossRef] [PubMed]

24. Wakai, K.; Egami, I.; Kato, K.; Kawamura, T.; Tamakoshi, A.; Lin, Y.; Nakayama, T.; Wada, M.; Ohno, Y. Dietary intake and sources of isoflavones among Japanese. Nutr. Cancer 1999, 33, 139-145. [CrossRef] [PubMed]

25. Kim, J.S.; Kwon, C.S. Estimated dietary isoflavone intake of Korean population based on National Nutrition Survey. Nutr. Res. 2001, 21, 947-953. [CrossRef]

26. Shu, X.O.; Jin, F.; Dai, Q.; Wen, W.; Potter, J.D.; Kushi, L.H.; Ruan, Z.; Gao, Y.T.; Zheng, W. Soyfood intake during adolescence and subsequent risk of breast cancer among Chinese women. Cancer Epidemiol. Biomark. Prev. 2001, 10, 483-488.

27. Ho, S.C.; Woo, J.L.; Leung, S.S.; Sham, A.L.; Lam, T.H.; Janus, E.D. Intake of soy products is associated with better plasma lipid profiles in the Hong Kong Chinese population. J. Nutr. 2000, 130, 2590-2593. [PubMed]

28. Huang, H.; Krishnan, H.B.; Pham, Q.; Yu, L.L.; Wang, T.T.Y. Soy and Gut Microbiota: Interaction and Implication for Human Health. J. Agric. Food Chem. 2016, 64, 8695-8709. [CrossRef] [PubMed]

29. Ho, S.C.; Chan, S.G.; Yip, Y.B.; Chan, C.S.Y.; Woo, J.L.F.; Sham, A. Change in bone mineral density and its determinants in pre- and perimenopausal Chinese women: The Hong Kong Perimenopausal Women Osteoporosis Study. Osteoporos. Int. 2008, 19, 1785-1796. [CrossRef] [PubMed]

30. Cui, X.; Dai, Q.; Tseng, M.; Shu, X.-O.; Gao, Y.-T.; Zheng, W. Dietary patterns and breast cancer risk in the shanghai breast cancer study. Cancer Epidemiol. Epidemiol. Prev. 2007, 16, 1443-1448. [CrossRef] [PubMed]

31. Messina, M.; Nagata, C.; Wu, A.H. Estimated Asian adult soy protein and isoflavone intakes. Nutr. Cancer 2006, 55, 1-12. [CrossRef] [PubMed]

32. Nagata, C. Ecological study of the association between soy product intake and mortality from cancer and heart disease in Japan. Int. J. Epidemiol. 2000, 29, 832-836. [CrossRef] [PubMed]

33. Murphy, P.A.; Barua, K.; Hauck, C.C. Solvent extraction selection in the determination of isoflavones in soy foods. J. Chromatogr. B Analyt. Technol. Biomed. Life Sci. 2002, 777, 129-138. [CrossRef]

34. Morton, M.S.; Wilcox, G.; Wahlqvist, M.L.; Griffiths, K. Determination of lignans and isoflavonoids in human female plasma following dietary supplementation. J. Endocrinol. 1994, 142, 251-259. [CrossRef] [PubMed]

35. Morton, M.S.; Arisaka, O.; Miyake, N.; Morgan, L.D.; Evans, B.A.J. Phytoestrogen concentrations in serum from Japanese men and women over forty years of age. J. Nutr. 2002, 132, 3168-3171. [PubMed]

36. Van Erp-Baart, M.A.J.; Brants, H.A.M.; Kiely, M.; Mulligan, A.; Turrini, A.; Sermoneta, C.; Kilkkinen, A.; Valsta, L.M. Isoflavone intake in four different European countries: The VENUS approach. Br. J. Nutr. 2003, 89, S25-S30. [CrossRef] [PubMed]

37. Kim, M.K.; Kim, J.H.; Nam, S.J.; Ryu, S.; Kong, G. Dietary intake of soy protein and tofu in association with breast cancer risk based on a case-control study. Nutr. Cancer 2008, 60, 568-576. [CrossRef] [PubMed]

38. Bai, W.; Wang, C.; Ren, C. Intakes of total and individual flavonoids by US adults. Int. J. Food Sci. Nutr. 2014, 65, 9-20. [CrossRef] [PubMed] 
39. Zamora-Ros, R.; Knaze, V.; Luján-Barroso, L.; Kuhnle, G.G.C.; Mulligan, A.A.; Touillaud, M.; Slimani, N.; Romieu, I.; Powell, N.; Tumino, R.; et al. Dietary intakes and food sources of phytoestrogens in the European Prospective Investigation into Cancer and Nutrition (EPIC) 24-h dietary recall cohort. Eur. J. Clin. Nutr. 2012, 66, 932-941. [CrossRef] [PubMed]

40. Horn-Ross, P.L.; Lee, M.; John, E.M.; Koo, J. Sources of phytoestrogen exposure among non-Asian women in California, USA. Cancer Causes Control 2000, 11, 299-302. [CrossRef] [PubMed]

41. De Kleijn, M.J.; van der Schouw, Y.T.; Wilson, P.W.; Adlercreutz, H.; Mazur, W.; Grobbee, D.E.; Jacques, P.F. Intake of dietary phytoestrogens is low in postmenopausal women in the United States: The Framingham study (1-4). J. Nutr. 2001, 131, 1826-1832. [PubMed]

42. Boker, L.K.; Van der Schouw, Y.T.; De Kleijn, M.J.J.; Jacques, P.F.; Grobbee, D.E.; Peeters, P.H.M. Intake of dietary phytoestrogens by Dutch women. J. Nutr. 2002, 132, 1319-1328. [PubMed]

43. Keinan-Boker, L.; Peeters, P.H.M.; Mulligan, A.A.; Navarro, C.; Slimani, N.; Mattisson, I.; Lundin, E.; McTaggart, A.; Allen, N.E.; Overvad, K.; et al. Soy product consumption in 10 European countries: The European Prospective Investigation into Cancer and Nutrition (EPIC) study. Public Health Nutr. 2002, 5 , 1217-1226. [CrossRef] [PubMed]

44. Rosell, M.S.; Appleby, P.N.; Spencer, E.A.; Key, T.J. Soy intake and blood cholesterol concentrations: A cross-sectional study of 1033 pre- and postmenopausal women in the Oxford arm of the European Prospective Investigation into Cancer and Nutrition. Am. J. Clin. Nutr. 2004, 80, 1391-1396. [PubMed]

45. Vogiatzoglou, A.; Mulligan, A.A.; Lentjes, M.A.H.; Luben, R.N.; Spencer, J.P.E.; Schroeter, H.; Khaw, K.-T.; Kuhnle, G.G.C. Flavonoid intake in European adults (18 to 64 years). PLoS ONE 2015, 10, e0128132. [CrossRef] [PubMed]

46. Godos, J.; Rapisarda, G.; Marventano, S.; Galvano, F.; Mistretta, A.; Grosso, G. Association between polyphenol intake and adherence to the Mediterranean diet in Sicily, southern Italy. NFS J. 2017, 8, 1-7. [CrossRef]

47. Tresserra-Rimbau, A.; Medina-Remón, A.; Pérez-Jiménez, J.; Martínez-González, M.A.; Covas, M.I.; Corella, D.; Salas-Salvadó, J.; Gómez-Gracia, E.; Lapetra, J.; Arós, F.; et al. Dietary intake and major food sources of polyphenols in a Spanish population at high cardiovascular risk: The PREDIMED study. Nutr. Metab. Cardiovasc. Dis. 2013, 23, 953-959. [CrossRef] [PubMed]

48. Godos, J.; Marventano, S.; Mistretta, A.; Galvano, F.; Grosso, G. Dietary sources of polyphenols in the Mediterranean healthy Eating, Aging and Lifestyle (MEAL) study cohort. Int. J. Food Sci. Nutr. 2017, 68, 750-756. [CrossRef] [PubMed]

49. Grosso, G.; Stepaniak, U.; Topor-Mądry, R.; Szafraniec, K.; Pająk, A. Estimated dietary intake and major food sources of polyphenols in the Polish arm of the HAPIEE study. Nutrition 2014, 30, 1398-1403. [CrossRef] [PubMed]

50. Butler, T.L.; Fraser, G.E.; Beeson, W.L.; Knutsen, S.F.; Herring, R.P.; Chan, J.; Sabaté, J.; Montgomery, S.; Haddad, E.; Preston-Martin, S.; et al. Cohort profile: The Adventist Health Study-2 (AHS-2). Int. J. Epidemiol. 2008, 37, 260-265. [CrossRef] [PubMed]

51. Rizzo, N.S.; Jaceldo-Siegl, K.; Sabate, J.; Fraser, G.E. Nutrient profiles of vegetarian and nonvegetarian dietary patterns. J. Acad. Nutr. Diet. 2013, 113, 1610-1619. [CrossRef] [PubMed]

52. Jaceldo-Siegl, K.; Fraser, G.E.; Chan, J.; Franke, A.; Sabaté, J. Validation of soy protein estimates from a food-frequency questionnaire with repeated 24-h recalls and isoflavonoid excretion in overnight urine in a Western population with a wide range of soy intakes. Am. J. Clin. Nutr. 2008, 87, 1422-1427. [PubMed]

53. Frankenfeld, C.L.; Patterson, R.E.; Kalhorn, T.F.; Skor, H.E.; Howald, W.N.; Lampe, J.W. Validation of a soy food frequency questionnaire with plasma concentrations of isoflavones in US adults. J. Am. Diet. Assoc. 2002, 102, 1407-1413. [CrossRef]

54. Messina, M.; Messina, V. The role of soy in vegetarian diets. Nutrients 2010, 2, 855-888. [CrossRef] [PubMed]

55. Food and Agriculture Organization of the United Nations (FAO). FAOSTAT. Available online: http://www. fao.org/faostat/en/\#home (accessed on 6 September 2017).

56. Steinfeld, H.; Gerber, P.; Wassenaar, T.; Castel, V.; Rosales, M.; de Haan, C. Livestock's Long Shadow; Food and Agriculture Organization of the United Nations (FAO): Rome, Italy, 2006; ISBN 978-92-5-105571-7.

57. Ministero delle Politiche Agricole, Alimentari e Forestali (Mipaaf-Italia). Notifica a Ue Richiesta per Divieto Coltivazione Ogm in tutto il Territorio. Available online: https:/ / www.politicheagricole.it/flex/cm/pages/ ServeBLOB.php/L/IT/IDPagina/9284 (accessed on 11 September 2017). 
58. Directive (EU) 2015/412 of the European Parliament and of the Council of 11 March 2015. Available online: http:/ / eur-lex.europa.eu/legal-content/IT/TXT/?uri=OJ\%3AJOL_2015_068_R_0001 (accessed on 11 September 2017).

59. Genetically Modified Organisms_European Commission. Available online: http://ec.europa.eu/food/ dyna/gm_register/index_en.cfm (accessed on 29 November 2017).

60. De Vendômois, J.S.; Cellier, D.; Vélot, C.; Clair, E.; Mesnage, R.; Séralini, G.-E. Debate on GMOs health risks after statistical findings in regulatory tests. Int. J. Biol. Sci. 2010, 6, 590-598. [CrossRef] [PubMed]

61. Tokede, O.A.; Onabanjo, T.A.; Yansane, A.; Gaziano, J.M.; Djoussé, L. Soya products and serum lipids: A meta-analysis of randomised controlled trials. Br. J. Nutr. 2015, 114, 831-843. [CrossRef] [PubMed]

62. National Academy of Sciences, Engineering and Medicine. Genetically Engineered Crops: Experiences and Prospects; National Academies Press: Washington, DC, USA, 2016; ISBN 978-0-309-43738-7.

63. Lozovaya, V.V.; Lygin, A.V.; Ulanov, A.V.; Nelson, R.L.; Daydé, J.; Widholm, J.M. Effect of Temperature and Soil Moisture Status during Seed Development on Soybean Seed Isoflavone Concentration and Composition. Crop Sci. 2005, 45, 1934-1940. [CrossRef]

64. Bhagwat, S.; Haytowitz, D.B.; Wasswa-Kintu, S. USDA Special Interest Databases on Flavonoids. Available online: https:/ / data.nal.usda.gov / dataset/usda-special-interest-databases-flavonoids (accessed on 7 September 2017).

65. Friedman, M.; Brandon, D.L. Nutritional and health benefits of soy proteins. J. Agric. Food Chem. 2001, 49, 1069-1086. [CrossRef] [PubMed]

66. Montgomery, K.S. Soy protein. J. Perinat. Educ. 2003, 12, 42-45. [CrossRef] [PubMed]

67. Barnes, S.; Boersma, B.; Patel, R.; Kirk, M.; Darley-Usmar, V.M.; Kim, H.; Xu, J. Isoflavonoids and chronic disease: Mechanisms of action. BioFactors 2000, 12, 209-215. [CrossRef] [PubMed]

68. Mayr, U.; Butsch, A.; Schneider, S. Validation of two in vitro test systems for estrogenic activities with zearalenone, phytoestrogens and cereal extracts. Toxicology 1992, 74, 135-149. [CrossRef]

69. Yamaguchi, F.; Ota, Y.; Hatanaka, C. Extraction and purification of pectic polysaccharides from soybean okara and enzymatic analysis of their structures. Carbohydr. Polym. 1996, 30, 265-273. [CrossRef]

70. Armstrong, W.B.; Wan, X.S.; Kennedy, A.R.; Taylor, T.H.; Meyskens, F.L. Development of the Bowman-Birk inhibitor for oral cancer chemoprevention and analysis of Neu immunohistochemical staining intensity with Bowman-Birk inhibitor concentrate treatment. Laryngoscope 2003, 113, 1687-1702. [CrossRef] [PubMed]

71. Galvez, A.F.; Chen, N.; Macasieb, J.; de Lumen, B.O. Chemopreventive property of a soybean peptide (lunasin) that binds to deacetylated histones and inhibits acetylation. Cancer Res. 2001, 61, 7473-7478. [PubMed]

72. Lam, Y.; Galvez, A.; de Lumen, B.O. Lunasin suppresses E1A-mediated transformation of mammalian cells but does not inhibit growth of immortalized and established cancer cell lines. Nutr. Cancer 2003, 47, 88-94. [CrossRef] [PubMed]

73. Hata, Y.; Yamamoto, M.; Nakajima, K. Effects of Soybean Oligosaccharides on Human Digestive Organs. J. Clin. Biochem. Nutr. 1991, 10, 135-144. [CrossRef] [PubMed]

74. Yang, B.; Prasad, K.N.; Xie, H.; Lin, S.; Jiang, Y. Structural characteristics of oligosaccharides from soy sauce lees and their potential prebiotic effect on lactic acid bacteria. Food Chem. 2011, 126, 590-594. [CrossRef]

75. Espinosa-Martos, I.; Rupérez, P. Soybean oligosaccharides: Potential as new ingredients in functional food. Nutr. Hosp. 2006, 21, 92-96. [PubMed]

76. Kang, J.; Badger, T.M.; Ronis, M.J.J.; Wu, X. Non-isoflavone phytochemicals in soy and their health effects. J. Agric. Food Chem. 2010, 58, 8119-8133. [CrossRef] [PubMed]

77. Hu, J.; Lee, S.-O.; Hendrich, S.; Murphy, P.A. Quantification of the group B soyasaponins by high-performance liquid chromatography. J. Agric. Food Chem. 2002, 50, 2587-2594. [CrossRef] [PubMed]

78. Rao, A.V.; Sung, M.K. Saponins as anticarcinogens. J. Nutr. 1995, 125, 717S-724S. [PubMed]

79. Nakashima, H.; Okubo, K.; Honda, Y.; Tamura, T.; Matsuda, S.; Yamamoto, N. Inhibitory effect of glycosides like saponin from soybean on the infectivity of HIV in vitro. AIDS 1989, 3, 655-658. [CrossRef] [PubMed]

80. Rowlands, J.C.; Berhow, M.A.; Badger, T.M. Estrogenic and antiproliferative properties of soy sapogenols in human breast cancer cells in vitro. Food Chem. Toxicol. 2002, 40, 1767-1774. [CrossRef]

81. Fang, N.; Yu, S.; Badger, T.M. Comprehensive phytochemical profile of soy protein isolate. J. Agric. Food Chem. 2004, 52, 4012-4020. [CrossRef] [PubMed] 
82. Melina, V.; Craig, W.; Levin, S. Position of the Academy of Nutrition and Dietetics: Vegetarian Diets. J. Acad. Nutr. Diet. 2016, 116, 1970-1980. [CrossRef] [PubMed]

83. Istfan, N.; Murray, E.; Janghorbani, M.; Young, V.R. An evaluation of the nutritional value of a soy protein concentrate in young adult men using the short-term N-balance method. J. Nutr. 1983, 113, 2516-2523. [PubMed]

84. Scrimshaw, N.S.; Wayler, A.H.; Murray, E.; Steinke, F.H.; Rand, W.M.; Young, V.R. Nitrogen balance response in young men given one of two isolated soy proteins or milk proteins. J. Nutr. 1983, 113, 2492-2497. [PubMed]

85. Wayler, A.; Queiroz, E.; Scrimshaw, N.S.; Steinke, F.H.; Rand, W.M.; Young, V.R. Nitrogen balance studies in young men to assess the protein quality of an isolated soy protein in relation to meat proteins. J. Nutr. 1983, 113, 2485-2491. [PubMed]

86. Young, V.R.; Puig, M.; Queiroz, E.; Scrimshaw, N.S.; Rand, W.M. Evaluation of the protein quality of an isolated soy protein in young men: Relative nitrogen requirements and effect of methionine supplementation. Am. J. Clin. Nutr. 1984, 39, 16-24. [PubMed]

87. Young, V.R.; Wayler, A.; Garza, C.; Steinke, F.H.; Murray, E.; Rand, W.M.; Scrimshaw, N.S. A long-term metabolic balance study in young men to assess the nutritional quality of an isolated soy protein and beef proteins. Am. J. Clin. Nutr. 1984, 39, 8-15. [PubMed]

88. Beer, W.H.; Murray, E.; Oh, S.H.; Pedersen, H.E.; Wolfe, R.R.; Young, V.R. A long-term metabolic study to assess the nutritional value of and immunological tolerance to two soy-protein concentrates in adult humans. Am. J. Clin. Nutr. 1989, 50, 997-1007. [PubMed]

89. García, M.C.; Torre, M.; Marina, M.L.; Laborda, F. Composition and characterization of soyabean and related products. Crit. Rev. Food Sci. Nutr. 1997, 37, 361-391. [CrossRef] [PubMed]

90. Grieshop, C.M.; Fahey, G.C. Comparison of quality characteristics of soybeans from Brazil, China, and the United States. J. Agric. Food Chem. 2001, 49, 2669-2673. [CrossRef] [PubMed]

91. Grieshop, C.M.; Kadzere, C.T.; Clapper, G.M.; Flickinger, E.A.; Bauer, L.L.; Frazier, R.L.; Fahey, G.C. Chemical and nutritional characteristics of United States soybeans and soybean meals. J. Agric. Food Chem. 2003, 51, 7684-7691. [CrossRef] [PubMed]

92. Bressani, R.; Viteri, F.; Elías, L.G.; de Zaghi, S.; Alvarado, J.; Odell, A.D. Protein quality of a soybean protein textured food in experimental animals and children. J. Nutr. 1967, 93, 349-360. [PubMed]

93. Joint FAO/WHO Expert Consultation; World Health Organization; Food and Agriculture Organization of the United Nations. Protein Quality Evaluation: Report of the Joint FAO/WHO; FAO Food Nutrition Paper; FAO: Rome, Italy, 1991.

94. Protein-Elements within the Nutrition Facts Table-Food-Canadian Food Inspection Agency. Available online: http:/ / www.inspection.gc.ca/food/labelling/food-labelling-for-industry/nutrition-labelling/ elements-within-the-nutrition-facts-table/eng/1389206763218/1389206811747?chap=7\#s10c7 (accessed on 7 September 2017).

95. World Health Organization. Report of a Joint FAO/WHO/UNU Expert Consultation. Energy and Protein Requirements; World Health Organization: Geneva, Switzerland, 1985; Volume 724, pp. 1-206.

96. Food and Agriculture Organization of the United Nations. Dietary Protein Quality Evaluation in Human Nutrition; FAO: Rome, Italy, 2013; Volume 92, pp. 1-66.

97. Hughes, G.J.; Ryan, D.J.; Mukherjea, R.; Schasteen, C.S. Protein digestibility-corrected amino acid scores (PDCAAS) for soy protein isolates and concentrate: Criteria for evaluation. J. Agric. Food Chem. 2011, 59, 12707-12712. [CrossRef] [PubMed]

98. Schaafsma, G. The protein digestibility-corrected amino acid score. J. Nutr. 2000, 130, 1865S-1867S. [PubMed]

99. Rand, W.M.; Pellett, P.L.; Young, V.R. Meta-analysis of nitrogen balance studies for estimating protein requirements in healthy adults. Am. J. Clin. Nutr. 2003, 77, 109-127. [PubMed]

100. Gilani, G.S.; Cockell, K.A.; Sepehr, E. Effects of antinutritional factors on protein digestibility and amino acid availability in foods. J. AOAC Int. 2005, 88, 967-987. [PubMed]

101. Lee, W.T.; Weisell, R.; Albert, J.; Tomé, D.; Kurpad, A.V.; Uauy, R. Research Approaches and Methods for Evaluating the Protein Quality of Human Foods Proposed by an FAO Expert Working Group in 2014. J. Nutr. 2016, 146, 929-932. [CrossRef] [PubMed]

102. Istfan, N.; Murray, E.; Janghorbani, M.; Evans, W.J.; Young, V.R. The nutritional value of a soy protein concentrate (STAPRO-3200) for long-term protein nutritional maintenance in young men. J. Nutr. 1983, 113, 2524-2534. [PubMed] 
103. Amigo-Benavent, M.; Silván, J.M.; Moreno, F.J.; Villamiel, M.; Del Castillo, M.D. Protein quality, antigenicity, and antioxidant activity of soy-based foodstuffs. J. Agric. Food Chem. 2008, 56, 6498-6505. [CrossRef] [PubMed]

104. Mangano, K.M.; Sahni, S.; Kiel, D.P.; Tucker, K.L.; Dufour, A.B.; Hannan, M.T. Dietary protein is associated with musculoskeletal health independently of dietary pattern: The Framingham Third Generation Study. Am. J. Clin. Nutr. 2017, 105, 714-722. [CrossRef] [PubMed]

105. Sahni, S.; Mangano, K.M.; Hannan, M.T.; Kiel, D.P.; McLean, R.R. Higher Protein Intake Is Associated with Higher Lean Mass and Quadriceps Muscle Strength in Adult Men and Women. J. Nutr. 2015, 145, 1569-1575. [CrossRef] [PubMed]

106. Brown, E.C.; DiSilvestro, R.A.; Babaknia, A.; Devor, S.T. Soy versus whey protein bars: Effects on exercise training impact on lean body mass and antioxidant status. Nutr. J. 2004, 3, 22. [CrossRef] [PubMed]

107. Società Italiana di Nutrizione Umana (SINU). LARN: Livelli di Assunzione di Riferimento di Nutrienti ed Energia per la Popolazione Italiana; IV Revisione; SICS Editore; Società Italiana di Nutrizione Umana: Firenze, Italy, 2014; ISBN 978-88-906852-2-4.

108. U.S. Department of Agriculture (USDA). Questions and Answers on Alternate Protein Products (APP)—Food and Nutrition Service. Available online: https://www.fns.usda.gov/questions-and-answers-alternateprotein-products-app (accessed on 11 September 2017).

109. Setchell, K.D. Phytoestrogens: The biochemistry, physiology, and implications for human health of soy isoflavones. Am. J. Clin. Nutr. 1998, 68, 1333S-1346S. [PubMed]

110. Cabot, W. Phytoestrogens. J. Am. Acad. Orthop. Surg. 2003, 11, 153-156. [CrossRef] [PubMed]

111. Howitz, K.T.; Sinclair, D.A. Xenohormesis: Sensing the chemical cues of other species. Cell 2008, 133, 387-391. [CrossRef] [PubMed]

112. Lozovaya, V.V.; Lygin, A.V.; Zernova, O.V.; Ulanov, A.V.; Li, S.; Hartman, G.L.; Widholm, J.M. Modification of phenolic metabolism in soybean hairy roots through down regulation of chalcone synthase or isoflavone synthase. Planta 2007, 225, 665-679. [CrossRef] [PubMed]

113. Zabala, G.; Zou, J.; Tuteja, J.; Gonzalez, D.O.; Clough, S.J.; Vodkin, L.O. Transcriptome changes in the phenylpropanoid pathway of Glycine max in response to Pseudomonas syringae infection. BMC Plant Biol. 2006, 6, 26. [CrossRef] [PubMed]

114. Subramanian, S.; Stacey, G.; Yu, O. Endogenous isoflavones are essential for the establishment of symbiosis between soybean and Bradyrhizobium japonicum. Plant J. 2006, 48, 261-273. [CrossRef] [PubMed]

115. Sugiyama, A.; Shitan, N.; Yazaki, K. Involvement of a soybean ATP-binding cassette-type transporter in the secretion of genistein, a signal flavonoid in legume-Rhizobium symbiosis. Plant Physiol. 2007, 144, 2000-2008. [CrossRef] [PubMed]

116. Mierziak, J.; Kostyn, K.; Kulma, A. Flavonoids as important molecules of plant interactions with the environment. Molecules 2014, 19, 16240-16265. [CrossRef] [PubMed]

117. Mazur, W.M.; Duke, J.A.; Wahala, K.; Rasku, S.; Adlercreutz, H. Isoflavonoids and lignans in legumes: Nutritional and health aspects in humans. J. Nutr. Biochem. 1998, 9, 193-200. [CrossRef]

118. USDA ARS. Nutrient Data Laboratory. Available online: https://www.ars.usda.gov/northeastarea/beltsville-md/beltsville-human-nutrition-research-center/nutrient-data-laboratory/ (accessed on 7 September 2017).

119. Thuzar, M.; Puteh, A.B.; Abdullah, N.A.P.; Lassim, M.B.M.; Jusoff, K. The Effects of Temperature Stress on the Quality and Yield of Soya Bean [(Glycine max L.) Merrill.]. J. Agric. Sci. 2010, 2, 172. [CrossRef]

120. Šertović, E.; Mujić, I.; Jokić, S.; Alibabić, V.; Sarić, Z. Effect of soybean cultivars on the content of isoflavones in soymilk. Rom. Biotechnol. Lett. 2012, 17, 7151-7159.

121. Wang, H.; Murphy, P.A. Isoflavone Composition of American and Japanese Soybeans in Iowa: Effects of Variety, Crop Year, and Location. J. Agric. Food Chem. 1994, 42, 1674-1677. [CrossRef]

122. Devi, M.K.A.; Gondi, M.; Sakthivelu, G.; Giridhar, P.; Rajasekaran, T.; Ravishankar, G.A. Functional attributes of soybean seeds and products, with reference to isoflavone content and antioxidant activity. Food Chem. 2009, 114, 771-776. [CrossRef]

123. Tham, D.M.; Gardner, C.D.; Haskell, W.L. Potential health benefits of dietary phytoestrogens: A review of the clinical, epidemiological, and mechanistic evidence. J. Clin. Endocrinol. Metab. 1998, 83, 2223-2235. [CrossRef] [PubMed] 
124. Breinholt, V.; Larsen, J.C. Detection of weak estrogenic flavonoids using a recombinant yeast strain and a modified MCF7 cell proliferation assay. Chem. Res. Toxicol. 1998, 11, 622-629. [CrossRef] [PubMed]

125. Kuiper, G.G.; Lemmen, J.G.; Carlsson, B.; Corton, J.C.; Safe, S.H.; van der Saag, P.T.; van der Burg, B.; Gustafsson, J.A. Interaction of estrogenic chemicals and phytoestrogens with estrogen receptor beta. Endocrinology 1998, 139, 4252-4263. [CrossRef] [PubMed]

126. Adlercreutz, H.; Markkanen, H.; Watanabe, S. Plasma concentrations of phyto-oestrogens in Japanese men. Lancet 1993, 342, 1209-1210. [CrossRef]

127. Kapiotis, S.; Hermann, M.; Held, I.; Seelos, C.; Ehringer, H.; Gmeiner, B.M. Genistein, the dietary-derived angiogenesis inhibitor, prevents LDL oxidation and protects endothelial cells from damage by atherogenic LDL. Arterioscler. Thromb. Vasc. Biol. 1997, 17, 2868-2874. [CrossRef] [PubMed]

128. Nilsson, S.; Gustafsson, J.-A. Biological role of estrogen and estrogen receptors. Crit. Rev. Biochem. Mol. Biol. 2002, 37, 1-28. [CrossRef] [PubMed]

129. Meegan, M.J.; Lloyd, D.G. Advances in the science of estrogen receptor modulation. Curr. Med. Chem. 2003, 10, 181-210. [CrossRef] [PubMed]

130. Riggs, B.L.; Hartmann, L.C. Selective estrogen-receptor modulators-Mechanisms of action and application to clinical practice. N. Engl. J. Med. 2003, 348, 618-629. [CrossRef] [PubMed]

131. Smith, C.L.; O'Malley, B.W. Coregulator function: A key to understanding tissue specificity of selective receptor modulators. Endocr. Rev. 2004, 25, 45-71. [CrossRef] [PubMed]

132. Liu, X.X.; Li, S.H.; Chen, J.Z.; Sun, K.; Wang, X.J.; Wang, X.G.; Hui, R.T. Effect of soy isoflavones on blood pressure: A meta-analysis of randomized controlled trials. Nutr. Metab. Cardiovasc. Dis. 2012, 22, 463-470. [CrossRef] [PubMed]

133. Hooper, L.; Ryder, J.J.; Kurzer, M.S.; Lampe, J.W.; Messina, M.J.; Phipps, W.R.; Cassidy, A. Effects of soy protein and isoflavones on circulating hormone concentrations in pre- and post-menopausal women: A systematic review and meta-analysis. Hum. Reprod. Update 2009, 15, 423-440. [CrossRef] [PubMed]

134. Matthews, J.; Gustafsson, J.-A. Estrogen signaling: A subtle balance between ER alpha and ER beta. Mol. Interv. 2003, 3, 281-292. [CrossRef] [PubMed]

135. Patel, R.P.; Boersma, B.J.; Crawford, J.H.; Hogg, N.; Kirk, M.; Kalyanaraman, B.; Parks, D.A.; Barnes, S.; Darley-Usmar, V. Antioxidant mechanisms of isoflavones in lipid systems: Paradoxical effects of peroxyl radical scavenging. Free Radic. Biol. Med. 2001, 31, 1570-1581. [CrossRef]

136. Nakajima, N.; Nozaki, N.; Ishihara, K.; Ishikawa, A.; Tsuji, H. Analysis of isoflavone content in tempeh, a fermented soybean, and preparation of a new isoflavone-enriched tempeh. J. Biosci. Bioeng. 2005, 100, 685-687. [CrossRef] [PubMed]

137. Murphy, P.A.; Song, T.; Buseman, G.; Barua, K.; Beecher, G.R.; Trainer, D.; Holden, J. Isoflavones in retail and institutional soy foods. J. Agric. Food Chem. 1999, 47, 2697-2704. [CrossRef] [PubMed]

138. Yamabe, S.; Kobayashi-Hattori, K.; Kaneko, K.; Endo, H.; Takita, T. Effect of soybean varieties on the content and composition of isoflavone in rice-koji miso. Food Chem. 2007, 100, 369-374. [CrossRef]

139. Otieno, D.O.; Ashton, J.F.; Shah, N.P. Isoflavone phytoestrogen degradation in fermented soymilk with selected beta-glucosidase producing L. acidophilus strains during storage at different temperatures. Int. J. Food Microbiol. 2007, 115, 79-88. [CrossRef] [PubMed]

140. David, L.A.; Maurice, C.F.; Carmody, R.N.; Gootenberg, D.B.; Button, J.E.; Wolfe, B.E.; Ling, A.V.; Devlin, A.S.; Varma, Y.; Fischbach, M.A.; et al. Diet rapidly and reproducibly alters the human gut microbiome. Nature 2014, 505, 559-563. [CrossRef] [PubMed]

141. Walker, A.W.; Ince, J.; Duncan, S.H.; Webster, L.M.; Holtrop, G.; Ze, X.; Brown, D.; Stares, M.D.; Scott, P.; Bergerat, A.; et al. Dominant and diet-responsive groups of bacteria within the human colonic microbiota. ISME J. 2011, 5, 220-230. [CrossRef] [PubMed]

142. De Filippo, C.; Cavalieri, D.; Di Paola, M.; Ramazzotti, M.; Poullet, J.B.; Massart, S.; Collini, S.; Pieraccini, G.; Lionetti, P. Impact of diet in shaping gut microbiota revealed by a comparative study in children from Europe and rural Africa. Proc. Natl. Acad. Sci. USA 2010, 107, 14691-14696. [CrossRef] [PubMed]

143. Lin, A.; Bik, E.M.; Costello, E.K.; Dethlefsen, L.; Haque, R.; Relman, D.A.; Singh, U. Distinct distal gut microbiome diversity and composition in healthy children from Bangladesh and the United States. PLoS ONE 2013, 8, e53838. [CrossRef] [PubMed]

144. Turnbaugh, P.J.; Gordon, J.I. The core gut microbiome, energy balance and obesity. J. Physiol. 2009, 587, 4153-4158. [CrossRef] [PubMed] 
145. Barnes, $\mathrm{S}$. The biochemistry, chemistry and physiology of the isoflavones in soybeans and their food products. Lymphat. Res. Biol. 2010, 8, 89-98. [CrossRef] [PubMed]

146. Collison, M.W. Determination of total soy isoflavones in dietary supplements, supplement ingredients, and soy foods by high-performance liquid chromatography with ultraviolet detection: Collaborative study. J. AOAC Int. 2008, 91, 489-500. [PubMed]

147. Mathias, K.; Ismail, B.; Corvalan, C.M.; Hayes, K.D. Heat and pH effects on the conjugated forms of genistin and daidzin isoflavones. J. Agric. Food Chem. 2006, 54, 7495-7502. [CrossRef] [PubMed]

148. Chiarello, M.D.; Le Guerroué, J.L.; Chagas, C.M.S.; Franco, O.L.; Bianchini, E.; João, M.J. Influence of Heat Treatment and Grain Germination on the Isoflavone Profile of Soy Milk. J. Food Biochem. 2006, 30, $234-247$. [CrossRef]

149. King, R.A.; Bursill, D.B. Plasma and urinary kinetics of the isoflavones daidzein and genistein after a single soy meal in humans. Am. J. Clin. Nutr. 1998, 67, 867-872. [PubMed]

150. Setchell, K.D.R.; Brown, N.M.; Lydeking-Olsen, E. The clinical importance of the metabolite equol-a clue to the effectiveness of soy and its isoflavones. J. Nutr. 2002, 132, 3577-3584. [PubMed]

151. Izumi, T.; Piskula, M.K.; Osawa, S.; Obata, A.; Tobe, K.; Saito, M.; Kataoka, S.; Kubota, Y.; Kikuchi, M. Soy isoflavone aglycones are absorbed faster and in higher amounts than their glucosides in humans. J. Nutr. 2000, 130, 1695-1699. [PubMed]

152. Setchell, K.D.; Brown, N.M.; Desai, P.; Zimmer-Nechemias, L.; Wolfe, B.E.; Brashear, W.T.; Kirschner, A.S.; Cassidy, A.; Heubi, J.E. Bioavailability of pure isoflavones in healthy humans and analysis of commercial soy isoflavone supplements. J. Nutr. 2001, 131, 1362S-1375S. [PubMed]

153. Axelson, M.; Kirk, D.N.; Farrant, R.D.; Cooley, G.; Lawson, A.M.; Setchell, K.D. The identification of the weak oestrogen equol [7-hydroxy-3-(4'-hydroxyphenyl)chroman] in human urine. Biochem. J. 1982, 201, 353-357. [CrossRef] [PubMed]

154. Atkinson, C.; Frankenfeld, C.L.; Lampe, J.W. Gut bacterial metabolism of the soy isoflavone daidzein: Exploring the relevance to human health. Exp. Biol. Med. 2005, 230, 155-170. [CrossRef]

155. Setchell, K.D.R.; Cole, S.J. Method of defining equol-producer status and its frequency among vegetarians. J. Nutr. 2006, 136, 2188-2193. [PubMed]

156. Bolca, S.; Possemiers, S.; Herregat, A.; Huybrechts, I.; Heyerick, A.; De Vriese, S.; Verbruggen, M.; Depypere, H.; De Keukeleire, D.; Bracke, M.; et al. Microbial and dietary factors are associated with the equol producer phenotype in healthy postmenopausal women. J. Nutr. 2007, 137, 2242-2246. [PubMed]

157. Setchell, K.D.; Borriello, S.P.; Hulme, P.; Kirk, D.N.; Axelson, M. Nonsteroidal estrogens of dietary origin: Possible roles in hormone-dependent disease. Am. J. Clin. Nutr. 1984, 40, 569-578. [PubMed]

158. Decroos, K.; Vanhemmens, S.; Cattoir, S.; Boon, N.; Verstraete, W. Isolation and characterisation of an equol-producing mixed microbial culture from a human faecal sample and its activity under gastrointestinal conditions. Arch. Microbiol. 2005, 183, 45-55. [CrossRef] [PubMed]

159. Wang, X.-L.; Hur, H.-G.; Lee, J.H.; Kim, K.T.; Kim, S.-I. Enantioselective synthesis of S-equol from dihydrodaidzein by a newly isolated anaerobic human intestinal bacterium. Appl. Environ. Microbiol. 2005, 71, 214-219. [CrossRef] [PubMed]

160. Rowland, I.R.; Wiseman, H.; Sanders, T.A.; Adlercreutz, H.; Bowey, E.A. Interindividual variation in metabolism of soy isoflavones and lignans: Influence of habitual diet on equol production by the gut microflora. Nutr. Cancer 2000, 36, 27-32. [CrossRef] [PubMed]

161. Lydeking-Olsen, E.; Beck-Jensen, J.E.; Setchell, K.D.R.; Holm-Jensen, T. Soymilk or progesterone for prevention of bone loss-A 2 years randomized, placebo-controlled trial. Eur. J. Nutr. 2004, 43, 246-257. [CrossRef] [PubMed]

162. Atkinson, C.; Berman, S.; Humbert, O.; Lampe, J.W. In vitro incubation of human feces with daidzein and antibiotics suggests interindividual differences in the bacteria responsible for equol production. J. Nutr. 2004, 134, 596-599. [PubMed]

163. Karr, S.C.; Lampe, J.W.; Hutchins, A.M.; Slavin, J.L. Urinary isoflavonoid excretion in humans is dose dependent at low to moderate levels of soy-protein consumption. Am. J. Clin. Nutr. 1997, 66, 46-51. [PubMed]

164. Kulling, S.E.; Honig, D.M.; Simat, T.J.; Metzler, M. Oxidative in vitro metabolism of the soy phytoestrogens daidzein and genistein. J. Agric. Food Chem. 2000, 48, 4963-4972. [CrossRef] [PubMed] 
165. Kulling, S.E.; Honig, D.M.; Metzler, M. Oxidative metabolism of the soy isoflavones daidzein and genistein in humans in vitro and in vivo. J. Agric. Food Chem. 2001, 49, 3024-3033. [CrossRef] [PubMed]

166. Sfakianos, J.; Coward, L.; Kirk, M.; Barnes, S. Intestinal uptake and biliary excretion of the isoflavone genistein in rats. J. Nutr. 1997, 127, 1260-1268. [PubMed]

167. Doerge, D.R.; Chang, H.C.; Churchwell, M.I.; Holder, C.L. Analysis of soy isoflavone conjugation in vitro and in human blood using liquid chromatography-mass spectrometry. Drug Metab. Dispos. Biol. Fate Chem. 2000, 28, 298-307. [PubMed]

168. Hargreaves, D.F.; Potten, C.S.; Harding, C.; Shaw, L.E.; Morton, M.S.; Roberts, S.A.; Howell, A.; Bundred, N.J. Two-week dietary soy supplementation has an estrogenic effect on normal premenopausal breast. J. Clin. Endocrinol. Metab. 1999, 84, 4017-4024. [CrossRef] [PubMed]

169. Maubach, J.; Bracke, M.E.; Heyerick, A.; Depypere, H.T.; Serreyn, R.F.; Mareel, M.M.; De Keukeleire, D. Quantitation of soy-derived phytoestrogens in human breast tissue and biological fluids by high-performance liquid chromatography. J. Chromatogr. B Analyt. Technol. Biomed. Life Sci. 2003, 784, 137-144. [CrossRef]

170. Morton, M.S.; Chan, P.S.; Cheng, C.; Blacklock, N.; Matos-Ferreira, A.; Abranches-Monteiro, L.; Correia, R.; Lloyd, S.; Griffiths, K. Lignans and isoflavonoids in plasma and prostatic fluid in men: Samples from Portugal, Hong Kong, and the United Kingdom. Prostate 1997, 32, 122-128. [CrossRef]

171. Hedlund, T.E.; Maroni, P.D.; Ferucci, P.G.; Dayton, R.; Barnes, S.; Jones, K.; Moore, R.; Ogden, L.G.; Wähälä, K.; Sackett, H.M.; et al. Long-term dietary habits affect soy isoflavone metabolism and accumulation in prostatic fluid in caucasian men. J. Nutr. 2005, 135, 1400-1406. [PubMed]

172. Mounts, T.L.; Warner, K.; List, G.R.; Kleiman, R.; Fehr, W.R.; Hammond, E.G.; Wilcox, J.R. Effect of altered fatty acid composition on soybean oil stability. J. Am. Oil Chem. Soc. 1988, 65, 624-628. [CrossRef]

173. Slavin, M.; Kenworthy, W.; Yu, L.L. Antioxidant properties, phytochemical composition, and antiproliferative activity of Maryland-grown soybeans with colored seed coats. J. Agric. Food Chem. 2009, 57, 11174-11185. [CrossRef] [PubMed]

174. Whent, M.; Hao, J.; Slavin, M.; Zhou, M.; Song, J.; Kenworthy, W.; Yu, L.L. Effect of genotype, environment, and their interaction on chemical composition and antioxidant properties of low-linolenic soybeans grown in Maryland. J. Agric. Food Chem. 2009, 57, 10163-10174. [CrossRef] [PubMed]

175. Jakobsen, M.U.; O’Reilly, E.J.; Heitmann, B.L.; Pereira, M.A.; Bälter, K.; Fraser, G.E.; Goldbourt, U.; Hallmans, G.; Knekt, P.; Liu, S.; et al. Major types of dietary fat and risk of coronary heart disease: A pooled analysis of 11 cohort studies. Am. J. Clin. Nutr. 2009, 89, 1425-1432. [CrossRef] [PubMed]

176. Mozaffarian, D.; Micha, R.; Wallace, S. Effects on coronary heart disease of increasing polyunsaturated fat in place of saturated fat: A systematic review and meta-analysis of randomized controlled trials. PLoS Med. 2010, 7, e1000252. [CrossRef] [PubMed]

177. Brouwer, I.A.; Katan, M.B.; Zock, P.L. Dietary alpha-linolenic acid is associated with reduced risk of fatal coronary heart disease, but increased prostate cancer risk: A meta-analysis. J. Nutr. 2004, 134, 919-922. [PubMed]

178. Dai, J.; Ziegler, T.R.; Bostick, R.M.; Manatunga, A.K.; Jones, D.P.; Goldberg, J.; Miller, A.; Vogt, G.; Wilson, P.W.; Jones, L.; et al. High habitual dietary alpha-linolenic acid intake is associated with decreased plasma soluble interleukin-6 receptor concentrations in male twins. Am. J. Clin. Nutr. 2010, 92, 177-185. [CrossRef] [PubMed]

179. Kiribuchi, M.; Miura, K.; Tokuda, S.; Kaneda, T. Hypocholesterolemic effect of triterpene alcohols with soysterol on plasma cholesterol in rats. J. Nutr. Sci. Vitaminol. 1983, 29, 35-43. [CrossRef] [PubMed]

180. Marshall, J.A.; Dennis, A.L.; Kumazawa, T.; Haynes, A.M.; Nes, W.D. Soybean sterol composition and utilization by Phytophthora sojae. Phytochemistry 2001, 58, 423-428. [CrossRef]

181. Piironen, V.; Lindsay, D.G.; Miettinen, T.A.; Toivo, J.; Lampi, A.-M. Plant sterols: Biosynthesis, biological function and their importance to human nutrition. J. Sci. Food Agric. 2000, 80, 939-966. [CrossRef]

182. Klingberg, S.; Ellegård, L.; Johansson, I.; Hallmans, G.; Weinehall, L.; Andersson, H.; Winkvist, A. Inverse relation between dietary intake of naturally occurring plant sterols and serum cholesterol in northern Sweden. Am. J. Clin. Nutr. 2008, 87, 993-1001. [PubMed]

183. Van Ee, J.H. Soy constituents: Modes of action in low-density lipoprotein management. Nutr. Rev. 2009, 67, 222-234. [CrossRef] [PubMed]

184. Ostlund, R.E. Phytosterols in human nutrition. Annu. Rev. Nutr. 2002, 22, 533-549. [CrossRef] [PubMed]

185. Peterson, D.W. Plant sterols and tissue cholesterol levels. Am. J. Clin. Nutr. 1958, 6, 644-649. [PubMed] 
186. Lin, X.; Ma, L.; Racette, S.B.; Anderson Spearie, C.L.; Ostlund, R.E. Phytosterol glycosides reduce cholesterol absorption in humans. Am. J. Physiol. Gastrointest. Liver Physiol. 2009, 296, G931-G935. [CrossRef] [PubMed]

187. Ostlund, R.E. Phytosterols, cholesterol absorption and healthy diets. Lipids 2007, 42, 41-45. [CrossRef] [PubMed]

188. Ostlund, R.E. Phytosterols and cholesterol metabolism. Curr. Opin. Lipidol. 2004, 15, 37-41. [CrossRef] [PubMed]

189. Moghadasian, M.H.; Frohlich, J.J. Effects of dietary phytosterols on cholesterol metabolism and atherosclerosis: Clinical and experimental evidence. Am. J. Med. 1999, 107, 588-594. [CrossRef]

190. Andersson, S.W.; Skinner, J.; Ellegård, L.; Welch, A.A.; Bingham, S.; Mulligan, A.; Andersson, H.; Khaw, K.T. Intake of dietary plant sterols is inversely related to serum cholesterol concentration in men and women in the EPIC Norfolk population: A cross-sectional study. Eur. J. Clin. Nutr. 2004, 58, 1378-1385. [CrossRef] [PubMed]

191. Escurriol, V.; Cofán, M.; Moreno-Iribas, C.; Larrañaga, N.; Martínez, C.; Navarro, C.; Rodríguez, L.; González, C.A.; Corella, D.; Ros, E. Phytosterol plasma concentrations and coronary heart disease in the prospective Spanish EPIC cohort. J. Lipid Res. 2010, 51, 618-624. [CrossRef] [PubMed]

192. Genser, B.; Silbernagel, G.; De Backer, G.; Bruckert, E.; Carmena, R.; Chapman, M.J.; Deanfield, J.; Descamps, O.S.; Rietzschel, E.R.; Dias, K.C.; et al. Plant sterols and cardiovascular disease: A systematic review and meta-analysis. Eur. Heart J. 2012, 33, 444-451. [CrossRef] [PubMed]

193. Calpe-Berdiel, L.; Escolà-Gil, J.C.; Blanco-Vaca, F. New insights into the molecular actions of plant sterols and stanols in cholesterol metabolism. Atherosclerosis 2009, 203, 18-31. [CrossRef] [PubMed]

194. Berger, A.; Jones, P.J.H.; Abumweis, S.S. Plant sterols: Factors affecting their efficacy and safety as functional food ingredients. Lipids Health Dis. 2004, 3, 5. [CrossRef] [PubMed]

195. Strandberg, T.E.; Gylling, H.; Tilvis, R.S.; Miettinen, T.A. Serum plant and other noncholesterol sterols, cholesterol metabolism and 22-year mortality among middle-aged men. Atherosclerosis 2010, 210, 282-287. [CrossRef] [PubMed]

196. Jaceldo-Siegl, K.; Lütjohann, D.; Sirirat, R.; Mashchak, A.; Fraser, G.E.; Haddad, E. Variations in dietary intake and plasma concentrations of plant sterols across plant-based diets among North American adults. Mol. Nutr. Food Res. 2017, 61. [CrossRef] [PubMed]

197. Rochfort, S.; Panozzo, J. Phytochemicals for health, the role of pulses. J. Agric. Food Chem. 2007, 55, 7981-7994. [CrossRef] [PubMed]

198. Messina, M.J. Legumes and soybeans: Overview of their nutritional profiles and health effects. Am. J. Clin. Nutr. 1999, 70, 439S-450S. [PubMed]

199. Peñalvo, J.L.; Heinonen, S.-M.; Nurmi, T.; Deyama, T.; Nishibe, S.; Adlercreutz, H. Plant lignans in soy-based health supplements. J. Agric. Food Chem. 2004, 52, 4133-4138. [CrossRef] [PubMed]

200. Schlemmer, U.; Frølich, W.; Prieto, R.M.; Grases, F. Phytate in foods and significance for humans: Food sources, intake, processing, bioavailability, protective role and analysis. Mol. Nutr. Food Res. 2009, 53, S330-S375. [CrossRef] [PubMed]

201. Lin, J.; Wang, C. Soybean saponins: Chemistry, analysis, and potential of health effects. In Soybeans as Functional Foods and Ingredients; AOCS Press: Columbia, MO, USA, 2004; pp. 73-100. ISBN 1-893997-33-2.

202. Shi, J.; Arunasalam, K.; Yeung, D.; Kakuda, Y.; Mittal, G.; Jiang, Y. Saponins from edible legumes: Chemistry, processing, and health benefits. J. Med. Food 2004, 7, 67-78. [CrossRef] [PubMed]

203. Potter, S.M. Overview of proposed mechanisms for the hypocholesterolemic effect of soy. J. Nutr. 1995, 125, 606S-611S. [PubMed]

204. Oakenfull, D. Saponins in food-A review. Food Chem. 1981, 7, 19-40. [CrossRef]

205. Decroos, K.; Vincken, J.P.; Heng, L.; Bakker, R.; Gruppen, H.; Verstraete, W. Simultaneous quantification of differently glycosylated, acetylated, and 2,3-dihydro-2,5-dihydroxy-6-methyl-4H-pyran-4-one-conjugated soyasaponins using reversed-phase high-performance liquid chromatography with evaporative light scattering detection. J. Chromatogr. A 2005, 1072, 185-193. [CrossRef] [PubMed]

206. Gestetner, B.; Birk, Y.; Tencer, Y. Soybean saponins. Fate of ingested soybean saponins and the physiological aspect of their hemolytic activity. J. Agric. Food Chem. 1968, 16, 1031-1035. [CrossRef]

207. Hu, J.; Reddy, M.B.; Hendrich, S.; Murphy, P.A. Soyasaponin I and sapongenol B have limited absorption by Caco-2 intestinal cells and limited bioavailability in women. J. Nutr. 2004, 134, 1867-1873. [PubMed] 
208. Hu, J.; Zheng, Y.L.; Hyde, W.; Hendrich, S.; Murphy, P.A. Human fecal metabolism of soyasaponin I. J. Agric. Food Chem. 2004, 52, 2689-2696. [CrossRef] [PubMed]

209. Güçlü-Ustündağ, O.; Mazza, G. Saponins: Properties, applications and processing. Crit. Rev. Food Sci. Nutr. 2007, 47, 231-258. [CrossRef] [PubMed]

210. Oakenfull, D.; Sidhu, G.S. Could saponins be a useful treatment for hypercholesterolaemia? Eur. J. Clin. Nutr. 1990, 44, 79-88. [PubMed]

211. Oakenfull, D.G.; Topping, D.L. Saponins and plasma cholesterol. Atherosclerosis 1983, 48, 301-303. [CrossRef]

212. Potter, J.; Topping, D.; Oakenfull, D. Soya, saponins, and plasma-cholesterol. Lancet 1979, 313, 223. [CrossRef]

213. Oakenfull, D. Soy protein, saponins and plasma cholesterol. J. Nutr. 2001, 131, 2971-2972. [PubMed]

214. Fonseca, N.D.; Villar, M.P.M.; Donangelo, C.M.; Perrone, D. Isoflavones and soyasaponins in soy infant formulas in Brazil: Profile and estimated consumption. Food Chem. 2014, 143, 492-498. [CrossRef] [PubMed]

215. Murphy, P.A.; Hu, J.; Barua, K.; Hauck, C.C. Group B Saponins in Soy Products in the U.S. Department of Agriculture-Iowa State University Isoflavone Database and Their Comparison with Isoflavone Contents. J. Agric. Food Chem. 2008, 56, 8534-8540. [CrossRef] [PubMed]

216. Clavel, T.; Doré, J.; Blaut, M. Bioavailability of lignans in human subjects. Nutr. Res. Rev. 2006, 19, 187-196. [CrossRef] [PubMed]

217. Heinonen, S.; Nurmi, T.; Liukkonen, K.; Poutanen, K.; Wähälä, K.; Deyama, T.; Nishibe, S.; Adlercreutz, H. In vitro metabolism of plant lignans: New precursors of mammalian lignans enterolactone and enterodiol. J. Agric. Food Chem. 2001, 49, 3178-3186. [CrossRef] [PubMed]

218. Wang, L.Q.; Meselhy, M.R.; Li, Y.; Qin, G.W.; Hattori, M. Human intestinal bacteria capable of transforming secoisolariciresinol diglucoside to mammalian lignans, enterodiol and enterolactone. Chem. Pharm. Bull. 2000, 48, 1606-1610. [CrossRef] [PubMed]

219. Carreau, C.; Flouriot, G.; Bennetau-Pelissero, C.; Potier, M. Enterodiol and enterolactone, two major diet-derived polyphenol metabolites have different impact on ERalpha transcriptional activation in human breast cancer cells. J. Steroid Biochem. Mol. Biol. 2008, 110, 176-185. [CrossRef] [PubMed]

220. HeYuan, J.; FeiJie, L.; JianXiang, T. Bioactive components of soyabeans and their functions. Soybean Sci. 2000, 19, 160-164.

221. Grases, F.; Simonet, B.M.; Vucenik, I.; Prieto, R.M.; Costa-Bauzá, A.; March, J.G.; Shamsuddin, A.M. Absorption and excretion of orally administered inositol hexaphosphate (IP(6) or phytate) in humans. BioFactors 2001, 15, 53-61. [CrossRef] [PubMed]

222. Murray-Kolb, L.E.; Welch, R.; Theil, E.C.; Beard, J.L. Women with low iron stores absorb iron from soybeans. Am. J. Clin. Nutr. 2003, 77, 180-184. [PubMed]

223. Zielińska-Dawidziak, M. Plant ferritin-A source of iron to prevent its deficiency. Nutrients 2015, 7, 1184-1201. [CrossRef] [PubMed]

224. Beard, J.L.; Burton, J.W.; Theil, E.C. Purified ferritin and soybean meal can be sources of iron for treating iron deficiency in rats. J. Nutr. 1996, 126, 154-160. [PubMed]

225. Vucenik, I.; Shamsuddin, A.M. Protection against cancer by dietary IP6 and inositol. Nutr. Cancer 2006, 55, 109-125. [CrossRef] [PubMed]

226. Heaney, R.P.; Weaver, C.M.; Fitzsimmons, M.L. Soybean phytate content: Effect on calcium absorption. Am. J. Clin. Nutr. 1991, 53, 745-747. [PubMed]

227. Omoni, A.O.; Aluko, R.E. Soybean foods and their benefits: Potential mechanisms of action. Nutr. Rev. 2005, 63, 272-283. [CrossRef] [PubMed]

228. Xiao, C.W. Health effects of soy protein and isoflavones in humans. J. Nutr. 2008, 138, 1244S-1299S. [PubMed]

229. Food and Drug Administration. Food labeling: Health claims; soy protein and coronary heart disease. Food and Drug Administration, HHS. Final rule. Fed. Regist. 1999, 64, 57700-57733.

230. Anderson, J.W.; Johnstone, B.M.; Cook-Newell, M.E. Meta-analysis of the effects of soy protein intake on serum lipids. N. Engl. J. Med. 1995, 333, 276-282. [CrossRef] [PubMed]

231. Benkhedda, K.; Boudrault, C.; Sinclair, S.E.; Marles, R.J.; Xiao, C.W.; Underhill, L. Food Risk Analysis Communication. Issued by health canada's food directorate. Health Canada's proposal to accept a health claim about soy products and cholesterol lowering. Int. Food Risk Anal. J. 2014, 4, 1-12. [CrossRef]

232. Harland, J.I.; Haffner, T.A. Systematic review, meta-analysis and regression of randomised controlled trials reporting an association between an intake of circa $25 \mathrm{~g}$ soya protein per day and blood cholesterol. Atherosclerosis 2008, 200, 13-27. [CrossRef] [PubMed] 
233. Zhan, S.; Ho, S.C. Meta-analysis of the effects of soy protein containing isoflavones on the lipid profile. Am. J. Clin. Nutr. 2005, 81, 397-408. [PubMed]

234. Nagata, C.; Takatsuka, N.; Kurisu, Y.; Shimizu, H. Decreased serum total cholesterol concentration is associated with high intake of soy products in Japanese men and women. J. Nutr. 1998, 128, 209-213. [PubMed]

235. Erdman, J.W. AHA Science Advisory: Soy protein and cardiovascular disease: A statement for healthcare professionals from the Nutrition Committee of the AHA. Circulation 2000, 102, 2555-2559. [CrossRef] [PubMed]

236. EFSA Panel on Dietetic Products, Nutrition and Allergies (NDA). Scientific Opinion on the substantiation of a health claim related to isolated soy protein and reduction of blood LDL-cholesterol concentrations pursuant to Article 14 of Regulation (EC) No 1924/2006: Isolated soy protein and reduction of blood LDL-cholesterol concentrations. EFSA J. 2012, 10, 2555. [CrossRef]

237. Cassidy, A.; Albertazzi, P.; Lise Nielsen, I.; Hall, W.; Williamson, G.; Tetens, I.; Atkins, S.; Cross, H.; Manios, Y.; Wolk, A.; et al. Critical review of health effects of soyabean phyto-oestrogens in post-menopausal women. Proc. Nutr. Soc. 2006, 65, 76-92. [CrossRef] [PubMed]

238. Russo, M.; Russo, G.L.; Daglia, M.; Kasi, P.D.; Ravi, S.; Nabavi, S.F.; Nabavi, S.M. Understanding genistein in cancer: The "good" and the "bad" effects: A review. Food Chem. 2016, 196, 589-600. [CrossRef] [PubMed]

239. Sarkar, F.H.; Li, Y. Soy isoflavones and cancer prevention. Cancer Investig. 2003, 21, 744-757. [CrossRef]

240. Badger, T.M.; Ronis, M.J.; Hakkak, R. Developmental effects and health aspects of soy protein isolate, casein, and whey in male and female rats. Int. J. Toxicol. 2001, 20, 165-174. [CrossRef] [PubMed]

241. Eason, R.R.; Till, S.R.; Velarde, M.C.; Geng, Y.; Chatman, L.; Gu, L.; Badger, T.M.; Simmen, F.A.; Simmen, R.C.M. Uterine phenotype of young adult rats exposed to dietary soy or genistein during development. J. Nutr. Biochem. 2005, 16, 625-632. [CrossRef] [PubMed]

242. Sharpe, R.M.; Martin, B.; Morris, K.; Greig, I.; McKinnell, C.; McNeilly, A.S.; Walker, M. Infant feeding with soy formula milk: Effects on the testis and on blood testosterone levels in marmoset monkeys during the period of neonatal testicular activity. Hum. Reprod. 2002, 17, 1692-1703. [CrossRef] [PubMed]

243. Safford, B.; Dickens, A.; Halleron, N.; Briggs, D.; Carthew, P.; Baker, V. A model to estimate the oestrogen receptor mediated effects from exposure to soy isoflavones in food. Regul. Toxicol. Pharmacol. 2003, 38, 196-209. [CrossRef]

244. Merritt, R.J.; Jenks, B.H. Safety of soy-based infant formulas containing isoflavones: The clinical evidence. J. Nutr. 2004, 134, 1220S-1224S. [PubMed]

245. Gu, L.; House, S.E.; Prior, R.L.; Fang, N.; Ronis, M.J.J.; Clarkson, T.B.; Wilson, M.E.; Badger, T.M. Metabolic phenotype of isoflavones differ among female rats, pigs, monkeys, and women. J. Nutr. 2006, 136, 1215-1221. [PubMed]

246. Wisniewski, A.B.; Klein, S.L.; Lakshmanan, Y.; Gearhart, J.P. Exposure to genistein during gestation and lactation demasculinizes the reproductive system in rats. J. Urol. 2003, 169, 1582-1586. [CrossRef] [PubMed]

247. Fielden, M.R.; Samy, S.M.; Chou, K.C.; Zacharewski, T.R. Effect of human dietary exposure levels of genistein during gestation and lactation on long-term reproductive development and sperm quality in mice. Food Chem. Toxicol. 2003, 41, 447-454. [CrossRef]

248. Ojeda, S.R.; Andrews, W.W.; Advis, J.P.; White, S.S. Recent advances in the endocrinology of puberty. Endocr. Rev. 1980, 1, 228-257. [CrossRef] [PubMed]

249. Robinson, J.D.; Judd, H.L.; Young, P.E.; Jones, O.W.; Yen, S.S. Amniotic fluid androgens and estrogens in midgestation. J. Clin. Endocrinol. Metab. 1977, 45, 755-761. [CrossRef] [PubMed]

250. Setchell, K.D.R.; Brown, N.M.; Zhao, X.; Lindley, S.L.; Heubi, J.E.; King, E.C.; Messina, M.J. Soy isoflavone phase II metabolism differs between rodents and humans: Implications for the effect on breast cancer risk. Am. J. Clin. Nutr. 2011, 94, 1284-1294. [CrossRef] [PubMed]

251. Soukup, S.T.; Helppi, J.; Müller, D.R.; Zierau, O.; Watzl, B.; Vollmer, G.; Diel, P.; Bub, A.; Kulling, S.E. Phase II metabolism of the soy isoflavones genistein and daidzein in humans, rats and mice: A cross-species and sex comparison. Arch. Toxicol. 2016, 90, 1335-1347. [CrossRef] [PubMed]

252. Van der Schouw, Y.T.; de Kleijn, M.J.; Peeters, P.H.; Grobbee, D.E. Phyto-oestrogens and cardiovascular disease risk. Nutr. Metab. Cardiovasc. Dis. 2000, 10, 154-167. [PubMed] 
253. Merz-Demlow, B.E.; Duncan, A.M.; Wangen, K.E.; Xu, X.; Carr, T.P.; Phipps, W.R.; Kurzer, M.S. Soy isoflavones improve plasma lipids in normocholesterolemic, premenopausal women. Am. J. Clin. Nutr. 2000, 71, 1462-1469. [PubMed]

254. Zhang, X.; Gao, Y.T.; Yang, G.; Li, H.; Cai, Q.; Xiang, Y.B.; Ji, B.T.; Franke, A.A.; Zheng, W.; Shu, X.O. Urinary isoflavonoids and risk of coronary heart disease. Int. J. Epidemiol. 2012, 41, 1367-1375. [CrossRef] [PubMed]

255. Ganry, O. Phytoestrogens and prostate cancer risk. Prev. Med. 2005, 41, 1-6. [CrossRef] [PubMed]

256. Nagata, Y.; Sonoda, T.; Mori, M.; Miyanaga, N.; Okumura, K.; Goto, K.; Naito, S.; Fujimoto, K.; Hirao, Y.; Takahashi, A.; et al. Dietary isoflavones may protect against prostate cancer in Japanese men. J. Nutr. 2007, 137, 1974-1979. [PubMed]

257. Zuniga, K.E.; Clinton, S.K.; Erdman, J.W. The interactions of dietary tomato powder and soy germ on prostate carcinogenesis in the TRAMP model. Cancer Prev. Res. 2013, 6, 548-557. [CrossRef] [PubMed]

258. Loibl, S.; Lintermans, A.; Dieudonné, A.S.; Neven, P. Management of menopausal symptoms in breast cancer patients. Maturitas 2011, 68, 148-154. [CrossRef] [PubMed]

259. Magee, P.J.; McGlynn, H.; Rowland, I.R. Differential effects of isoflavones and lignans on invasiveness of MDA-MB-231 breast cancer cells in vitro. Cancer Lett. 2004, 208, 35-41. [CrossRef] [PubMed]

260. Patisaul, H.B.; Jefferson, W. The pros and cons of phytoestrogens. Front. Neuroendocrinol. 2010, 31, 400-419. [CrossRef] [PubMed]

261. Peeters, P.H.M.; Keinan-Boker, L.; van der Schouw, Y.T.; Grobbee, D.E. Phytoestrogens and breast cancer risk: Review of the epidemiological evidence. IARC Sci. Publ. 2002, 156, 331-336. [CrossRef] [PubMed]

262. Grosso, G.; Bella, F.; Godos, J.; Sciacca, S.; Del Rio, D.; Ray, S.; Galvano, F.; Giovannucci, E.L. Possible role of diet in cancer: Systematic review and multiple meta-analyses of dietary patterns, lifestyle factors, and cancer risk. Nutr. Rev. 2017, 75, 405-419. [CrossRef] [PubMed]

263. Adlercreutz, H. Western diet and Western diseases: Some hormonal and biochemical mechanisms and associations. Scand. J. Clin. Lab. Investig. Suppl. 1990, 201, 3-23. [CrossRef]

264. Adlercreutz, H.; Mazur, W. Phyto-oestrogens and Western diseases. Ann. Med. 1997, 29, 95-120. [CrossRef] [PubMed]

265. Messina, M.J.; Persky, V.; Setchell, K.D.; Barnes, S. Soy intake and cancer risk: A review of the in vitro and in vivo data. Nutr. Cancer 1994, 21, 113-131. [CrossRef] [PubMed]

266. Taku, K.; Melby, M.K.; Kronenberg, F.; Kurzer, M.S.; Messina, M. Extracted or synthesized soybean isoflavones reduce menopausal hot flash frequency and severity: Systematic review and meta-analysis of randomized controlled trials. Menopause 2012, 19, 776-790. [CrossRef] [PubMed]

267. Clarkson, T.B. Soy phytoestrogens: What will be their role in postmenopausal hormone replacement therapy? Menopause 2000, 7, 71-75. [PubMed]

268. Alekel, D.L.; Germain, A.S.; Peterson, C.T.; Hanson, K.B.; Stewart, J.W.; Toda, T. Isoflavone-rich soy protein isolate attenuates bone loss in the lumbar spine of perimenopausal women. Am. J. Clin. Nutr. 2000, 72, 844-852. [PubMed]

269. Horiuchi, T.; Onouchi, T.; Takahashi, M.; Ito, H.; Orimo, H. Effect of soy protein on bone metabolism in postmenopausal Japanese women. Osteoporos. Int. 2000, 11, 721-724. [CrossRef] [PubMed]

270. Wangen, K.E.; Duncan, A.M.; Merz-Demlow, B.E.; Xu, X.; Marcus, R.; Phipps, W.R.; Kurzer, M.S. Effects of soy isoflavones on markers of bone turnover in premenopausal and postmenopausal women. J. Clin. Endocrinol. Metab. 2000, 85, 3043-3048. [CrossRef] [PubMed]

271. Ma, D.F.; Qin, L.Q.; Wang, P.Y.; Katoh, R. Soy isoflavone intake inhibits bone resorption and stimulates bone formation in menopausal women: Meta-analysis of randomized controlled trials. Eur. J. Clin. Nutr. 2008, 62, 155-161. [CrossRef] [PubMed]

272. Wei, P.; Liu, M.; Chen, Y.; Chen, D.C. Systematic review of soy isoflavone supplements on osteoporosis in women. Asian Pac. J. Trop. Med. 2012, 5, 243-248. [CrossRef]

273. Velasquez, M.T.; Bhathena, S.J. Role of dietary soy protein in obesity. Int. J. Med. Sci. 2007, 4, 72-82. [CrossRef] [PubMed]

274. Henderson, V.W.; Paganini-Hill, A.; Miller, B.L.; Elble, R.J.; Reyes, P.F.; Shoupe, D.; McCleary, C.A.; Klein, R.A.; Hake, A.M.; Farlow, M.R. Estrogen for Alzheimer's disease in women: Randomized, double-blind, placebo-controlled trial. Neurology 2000, 54, 295-301. [CrossRef] [PubMed]

275. Bingham, S.A.; Atkinson, C.; Liggins, J.; Bluck, L.; Coward, A. Phyto-oestrogens: Where are we now? Br. J. Nutr. 1998, 79, 393-406. [CrossRef] [PubMed] 
276. Zhang, E.J.; Ng, K.M.; Luo, K.Q. Extraction and purification of isoflavones from soybeans and characterization of their estrogenic activities. J. Agric. Food Chem. 2007, 55, 6940-6950. [CrossRef] [PubMed]

277. Adlercreutz, H.; Fotsis, T.; Lampe, J.; Wähälä, K.; Mäkelä, T.; Brunow, G.; Hase, T. Quantitative determination of lignans and isoflavonoids in plasma of omnivorous and vegetarian women by isotope dilution gas chromatography-mass spectrometry. Scand. J. Clin. Lab. Investig. Suppl. 1993, 215, 5-18. [CrossRef]

278. Irvine, C.; Fitzpatrick, M.; Robertson, I.; Woodhams, D. The potential adverse effects of soybean phytoestrogens in infant feeding. N. Z. Med. J. 1995, 108, 208-209. [PubMed]

279. Sheehan, D.M. Herbal medicines, phytoestrogens and toxicity: Risk:benefit considerations. Proc. Soc. Exp. Biol. Med. 1998, 217, 379-385. [CrossRef] [PubMed]

280. Divi, R.L.; Chang, H.C.; Doerge, D.R. Anti-thyroid isoflavones from soybean: Isolation, characterization, and mechanisms of action. Biochem. Pharmacol. 1997, 54, 1087-1096. [CrossRef]

281. Sun, C.L.; Yuan, J.M.; Arakawa, K.; Low, S.H.; Lee, H.P.; Yu, M.C. Dietary soy and increased risk of bladder cancer: The Singapore Chinese Health Study. Cancer Epidemiol. Biomark. Prev. 2002, 11, 1674-1677.

282. White, L.; Petrovitch, H.; Ross, G.W.; Masaki, K.H.; Abbott, R.D.; Teng, E.L.; Rodriguez, B.L.; Blanchette, P.L.; Havlik, R.J.; Wergowske, G.; et al. Prevalence of dementia in older Japanese-American men in Hawaii: The Honolulu-Asia Aging Study. JAMA 1996, 276, 955-960. [CrossRef] [PubMed]

283. McMichael-Phillips, D.F.; Harding, C.; Morton, M.; Roberts, S.A.; Howell, A.; Potten, C.S.; Bundred, N.J. Effects of soy-protein supplementation on epithelial proliferation in the histologically normal human breast. Am. J. Clin. Nutr. 1998, 68, 1431S-1435S. [PubMed]

284. Petrakis, N.L.; Barnes, S.; King, E.B.; Lowenstein, J.; Wiencke, J.; Lee, M.M.; Miike, R.; Kirk, M.; Coward, L. Stimulatory influence of soy protein isolate on breast secretion in pre- and postmenopausal women. Cancer Epidemiol. Biomark. Prev. 1996, 5, 785-794.

285. Li, Y.; Saldanha, S.N.; Tollefsbol, T.O. Impact of epigenetic dietary compounds on transgenerational prevention of human diseases. AAPS J. 2014, 16, 27-36. [CrossRef] [PubMed]

286. Setchell, K.D.; Cassidy, A. Dietary isoflavones: Biological effects and relevance to human health. J. Nutr. 1999, 129, 758S-767S. [PubMed]

287. Adlercreutz, H.; Honjo, H.; Higashi, A.; Fotsis, T.; Hämäläinen, E.; Hasegawa, T.; Okada, H. Urinary excretion of lignans and isoflavonoid phytoestrogens in Japanese men and women consuming a traditional Japanese diet. Am. J. Clin. Nutr. 1991, 54, 1093-1100. [PubMed]

288. Price, K.R.; Fenwick, G.R. Naturally occurring oestrogens in foods-A review. Food Addit. Contam. 1985, 2, 73-106. [CrossRef] [PubMed]

289. Knight, D.C.; Eden, J.A. Phytoestrogens-A short review. Maturitas 1995, 22, 167-175. [CrossRef]

290. Mazur, W. Phytoestrogen content in foods. Baillieres Clin. Endocrinol. Metab. 1998, 12, 729-742. [CrossRef]

291. Mazur, W.; Fotsis, T.; Wähälä, K.; Ojala, S.; Salakka, A.; Adlercreutz, H. Isotope dilution gas chromatographic-mass spectrometric method for the determination of isoflavonoids, coumestrol, and lignans in food samples. Anal. Biochem. 1996, 233, 169-180. [CrossRef] [PubMed]

292. Mazur, W.M.; Wähälä, K.; Rasku, S.; Salakka, A.; Hase, T.; Adlercreutz, H. Lignan and isoflavonoid concentrations in tea and coffee. Br. J. Nutr. 1998, 79, 37-45. [CrossRef] [PubMed]

293. Martinez-Villaluenga, C.; Bringe, N.A.; Berhow, M.A.; Gonzalez de Mejia, E. Beta-conglycinin embeds active peptides that inhibit lipid accumulation in 3T3-L1 adipocytes in vitro. J. Agric. Food Chem. 2008, 56, 10533-10543. [CrossRef] [PubMed]

294. Martinez-Villaluenga, C.; Dia, V.P.; Berhow, M.; Bringe, N.A.; Gonzalez de Mejia, E. Protein hydrolysates from beta-conglycinin enriched soybean genotypes inhibit lipid accumulation and inflammation in vitro. Mol. Nutr. Food Res. 2009, 53, 1007-1018. [CrossRef] [PubMed]

295. Martinez-Villaluenga, C.; Rupasinghe, S.G.; Schuler, M.A.; Gonzalez de Mejia, E. Peptides from purified soybean beta-conglycinin inhibit fatty acid synthase by interaction with the thioesterase catalytic domain. FEBS J. 2010, 277, 1481-1493. [CrossRef] [PubMed]

296. Wang, W.; Bringe, N.A.; Berhow, M.A.; Gonzalez de Mejia, E. beta-Conglycinins among sources of bioactives in hydrolysates of different soybean varieties that inhibit leukemia cells in vitro. J. Agric. Food Chem. 2008, 56, 4012-4020. [CrossRef] [PubMed]

297. Messina, M. Soy and Health Update: Evaluation of the Clinical and Epidemiologic Literature. Nutrients 2016, 8, 754. [CrossRef] [PubMed] 
298. Grosso, G.; Micek, A.; Godos, J.; Pajak, A.; Sciacca, S.; Galvano, F.; Giovannucci, E.L. Dietary Flavonoid and Lignan Intake and Mortality in Prospective Cohort Studies: Systematic Review and Dose-Response Meta-Analysis. Am. J. Epidemiol. 2017, 1-13. [CrossRef] [PubMed]

299. Hodges, R.E.; Krehl, W.A.; Stone, D.B.; Lopez, A. Dietary carbohydrates and low cholesterol diets: Effects on serum lipids on man. Am. J. Clin. Nutr. 1967, 20, 198-208. [PubMed]

300. Jenkins, D.J.A.; Mirrahimi, A.; Srichaikul, K.; Berryman, C.E.; Wang, L.; Carleton, A.; Abdulnour, S.; Sievenpiper, J.L.; Kendall, C.W.C.; Kris-Etherton, P.M. Soy protein reduces serum cholesterol by both intrinsic and food displacement mechanisms. J. Nutr. 2010, 140, 2302S-2311S. [CrossRef] [PubMed]

301. Wei, H.; Bowen, R.; Cai, Q.; Barnes, S.; Wang, Y. Antioxidant and antipromotional effects of the soybean isoflavone genistein. Proc. Soc. Exp. Biol. Med. 1995, 208, 124-130. [CrossRef] [PubMed]

302. Djuric, Z.; Chen, G.; Doerge, D.R.; Heilbrun, L.K.; Kucuk, O. Effect of soy isoflavone supplementation on markers of oxidative stress in men and women. Cancer Lett. 2001, 172, 1-6. [CrossRef]

303. Rimbach, G.; Weinberg, P.D.; de Pascual-Teresa, S.; Alonso, M.G.; Ewins, B.A.; Turner, R.; Minihane, A.M.; Botting, N.; Fairley, B.; Matsugo, S.; et al. Sulfation of genistein alters its antioxidant properties and its effect on platelet aggregation and monocyte and endothelial function. Biochim. Biophys. Acta 2004, 1670, 229-237. [CrossRef] [PubMed]

304. Wiseman, H.; O’Reilly, J.D.; Adlercreutz, H.; Mallet, A.I.; Bowey, E.A.; Rowland, I.R.; Sanders, T.A. Isoflavone phytoestrogens consumed in soy decrease $\mathrm{F}(2)$-isoprostane concentrations and increase resistance of low-density lipoprotein to oxidation in humans. Am. J. Clin. Nutr. 2000, 72, 395-400. [PubMed]

305. Sirtori, C.R.; Even, R.; Lovati, M.R. Soybean protein diet and plasma cholesterol: From therapy to molecular mechanisms. Ann. N. Y. Acad. Sci. 1993, 676, 188-201. [CrossRef] [PubMed]

306. Sacks, F.M.; Lichtenstein, A.; Van Horn, L.; Harris, W.; Kris-Etherton, P.; Winston, M.; American Heart Association Nutrition Committee. Soy protein, isoflavones, and cardiovascular health: An American Heart Association Science Advisory for professionals from the Nutrition Committee. Circulation 2006, 113, 1034-1044. [CrossRef] [PubMed]

307. Brown, L.; Rosner, B.; Willett, W.W.; Sacks, F.M. Cholesterol-lowering effects of dietary fiber: A meta-analysis. Am. J. Clin. Nutr. 1999, 69, 30-42. [PubMed]

308. Dong, J.Y.; Tong, X.; Wu, Z.W.; Xun, P.C.; He, K.; Qin, L.Q. Effect of soya protein on blood pressure: A meta-analysis of randomised controlled trials. Br. J. Nutr. 2011, 106, 317-326. [CrossRef] [PubMed]

309. Grosso, G.; Stepaniak, U.; Micek, A.; Kozela, M.; Stefler, D.; Bobak, M.; Pajak, A. Dietary polyphenol intake and risk of hypertension in the Polish arm of the HAPIEE study. Eur. J. Nutr. 2017. [CrossRef] [PubMed]

310. Ding, M.; Pan, A.; Manson, J.E.; Willett, W.C.; Malik, V.; Rosner, B.; Giovannucci, E.; Hu, F.B.; Sun, Q. Consumption of soy foods and isoflavones and risk of type 2 diabetes: A pooled analysis of three US cohorts. Eur. J. Clin. Nutr. 2016, 70, 1381-1387. [CrossRef] [PubMed]

311. Grosso, G.; Stepaniak, U.; Micek, A.; Kozela, M.; Stefler, D.; Bobak, M.; Pajak, A. Dietary polyphenol intake and risk of type 2 diabetes in the Polish arm of the Health, Alcohol and Psychosocial factors in Eastern Europe (HAPIEE) study. Br. J. Nutr. 2017, 118, 60-68. [CrossRef] [PubMed]

312. Zamora-Ros, R.; Forouhi, N.G.; Sharp, S.J.; González, C.A.; Buijsse, B.; Guevara, M.; van der Schouw, Y.T.; Amiano, P.; Boeing, H.; Bredsdorff, L.; et al. The association between dietary flavonoid and lignan intakes and incident type 2 diabetes in European populations: The EPIC-InterAct study. Diabetes Care 2013, 36, 3961-3970. [CrossRef] [PubMed]

313. Nanri, A.; Mizoue, T.; Takahashi, Y.; Kirii, K.; Inoue, M.; Noda, M.; Tsugane, S. Soy product and isoflavone intakes are associated with a lower risk of type 2 diabetes in overweight Japanese women. J. Nutr. 2010, 140, 580-586. [CrossRef] [PubMed]

314. Yan, Z.; Zhang, X.; Li, C.; Jiao, S.; Dong, W. Association between consumption of soy and risk of cardiovascular disease: A meta-analysis of observational studies. Eur. J. Prev. Cardiol. 2017, 24, 735-747. [CrossRef] [PubMed]

315. Sirtori, C.R.; Galli, C.; Anderson, J.W.; Sirtori, E.; Arnoldi, A. Functional foods for dyslipidaemia and cardiovascular risk prevention. Nutr. Res. Rev. 2009, 22, 244-261. [CrossRef] [PubMed]

316. Curtis, P.J.; Sampson, M.; Potter, J.; Dhatariya, K.; Kroon, P.A.; Cassidy, A. Chronic ingestion of flavan-3-ols and isoflavones improves insulin sensitivity and lipoprotein status and attenuates estimated 10-year CVD risk in medicated postmenopausal women with type 2 diabetes: A 1-year, double-blind, randomized, controlled trial. Diabetes Care 2012, 35, 226-232. [CrossRef] [PubMed] 
317. González Cañete, N.; Durán Agüero, S. Soya isoflavones and evidences on cardiovascular protection. Nutr. Hosp. 2014, 29, 1271-1282. [CrossRef] [PubMed]

318. Shu, X.O.; Zheng, Y.; Cai, H.; Gu, K.; Chen, Z.; Zheng, W.; Lu, W. Soy food intake and breast cancer survival. JAMA 2009, 302, 2437-2443. [CrossRef] [PubMed]

319. Caan, B.J.; Natarajan, L.; Parker, B.; Gold, E.B.; Thomson, C.; Newman, V.; Rock, C.L.; Pu, M.; Al-Delaimy, W.; Pierce, J.P. Soy food consumption and breast cancer prognosis. Cancer Epidemiol. Biomark. Prev. 2011, 20, 854-858. [CrossRef] [PubMed]

320. Lee, S.A.; Shu, X.O.; Li, H.; Yang, G.; Cai, H.; Wen, W.; Ji, B.T.; Gao, J.; Gao, Y.T.; Zheng, W. Adolescent and adult soy food intake and breast cancer risk: Results from the Shanghai Women's Health Study. Am. J. Clin. Nutr. 2009, 89, 1920-1926. [CrossRef] [PubMed]

321. Banerjee, S.; Li, Y.; Wang, Z.; Sarkar, F.H. Multi-targeted therapy of cancer by genistein. Cancer Lett. 2008, 269, 226-242. [CrossRef] [PubMed]

322. Messina, M.; Kucuk, O.; Lampe, J.W. An overview of the health effects of isoflavones with an emphasis on prostate cancer risk and prostate-specific antigen levels. J. AOAC Int. 2006, 89, 1121-1134. [PubMed]

323. Zhou, J.R.; Gugger, E.T.; Tanaka, T.; Guo, Y.; Blackburn, G.L.; Clinton, S.K. Soybean phytochemicals inhibit the growth of transplantable human prostate carcinoma and tumor angiogenesis in mice. J. Nutr. 1999, 129, 1628-1635. [PubMed]

324. Vitale, S.G.; Laganà, A.S.; Nigro, A.; La Rosa, V.L.; Rossetti, P.; Rapisarda, A.M.C.; La Vignera, S.; Condorelli, R.A.; Corrado, F.; Buscema, M.; et al. Peroxisome Proliferator-Activated Receptor Modulation during Metabolic Diseases and Cancers: Master and Minions. PPAR Res. 2016, 2016, 6517313. [CrossRef] [PubMed]

325. Nagata, C.; Mizoue, T.; Tanaka, K.; Tsuji, I.; Tamakoshi, A.; Matsuo, K.; Wakai, K.; Inoue, M.; Tsugane, S.; Sasazuki, S.; et al. Soy Intake and Breast Cancer Risk: An Evaluation Based on a Systematic Review of Epidemiologic Evidence Among the Japanese Population. Jpn. J. Clin. Oncol. 2014, 44, 282-295. [CrossRef] [PubMed]

326. Akaza, H. Prostate cancer chemoprevention by soy isoflavones: Role of intestinal bacteria as the "second human genome". Cancer Sci. 2012, 103, 969-975. [CrossRef] [PubMed]

327. Hamilton-Reeves, J.M.; Banerjee, S.; Banerjee, S.K.; Holzbeierlein, J.M.; Thrasher, J.B.; Kambhampati, S.; Keighley, J.; Van Veldhuizen, P. Short-term soy isoflavone intervention in patients with localized prostate cancer: A randomized, double-blind, placebo-controlled trial. PLoS ONE 2013, 8, e68331. [CrossRef] [PubMed]

328. Dalais, F.S.; Meliala, A.; Wattanapenpaiboon, N.; Frydenberg, M.; Suter, D.A.I.; Thomson, W.K.; Wahlqvist, M.L. Effects of a diet rich in phytoestrogens on prostate-specific antigen and sex hormones in men diagnosed with prostate cancer. Urology 2004, 64, 510-515. [CrossRef] [PubMed]

329. Pendleton, J.M.; Tan, W.W.; Anai, S.; Chang, M.; Hou, W.; Shiverick, K.T.; Rosser, C.J. Phase II trial of isoflavone in prostate-specific antigen recurrent prostate cancer after previous local therapy. BMC Cancer 2008, 8, 132. [CrossRef] [PubMed]

330. Yan, L.; Spitznagel, E.L. Soy consumption and prostate cancer risk in men: A revisit of a meta-analysis. Am. J. Clin. Nutr. 2009, 89, 1155-1163. [CrossRef] [PubMed]

331. Van Die, M.D.; Bone, K.M.; Williams, S.G.; Pirotta, M.V. Soy and soy isoflavones in prostate cancer: A systematic review and meta-analysis of randomized controlled trials. BJU Int. 2014, 113, E119-E130. [CrossRef] [PubMed]

332. Kuriyama, I.; Takahashi, Y.; Yoshida, H.; Mizushina, Y. Inhibitory Effect of Isoflavones from Processed Soybeans on Human DNA Topoisomerase II Activity. J. Plant Biochem. Physiol. 2013. [CrossRef]

333. Dagdemir, A.; Durif, J.; Ngollo, M.; Bignon, Y.J.; Bernard-Gallon, D. Histone lysine trimethylation or acetylation can be modulated by phytoestrogen, estrogen or anti-HDAC in breast cancer cell lines. Epigenomics 2013, 5, 51-63. [CrossRef] [PubMed]

334. Dagdemir, A.; Durif, J.; Ngollo, M.; Bignon, Y.J.; Bernard-Gallon, D. Breast cancer: Mechanisms involved in action of phytoestrogens and epigenetic changes. In Vivo 2013, 27, 1-9. [PubMed]

335. Hilakivi-Clarke, L.; Andrade, J.E.; Helferich, W. Is soy consumption good or bad for the breast? J. Nutr. 2010, 140, 2326S-2334S. [CrossRef] [PubMed]

336. Yu, Y.; Jing, X.; Li, H.; Zhao, X.; Wang, D. Soy isoflavone consumption and colorectal cancer risk: A systematic review and meta-analysis. Sci. Rep. 2016, 6, 25939. [CrossRef] [PubMed] 
337. Zhong, X.S.; Ge, J.; Chen, S.W.; Xiong, Y.Q.; Ma, S.J.; Chen, Q. Association between Dietary Isoflavones in Soy and Legumes and Endometrial Cancer: A Systematic Review and Meta-Analysis. J. Acad. Nutr. Diet. 2016. [CrossRef] [PubMed]

338. Korde, L.A.; Wu, A.H.; Fears, T.; Nomura, A.M.Y.; West, D.W.; Kolonel, L.N.; Pike, M.C.; Hoover, R.N.; Ziegler, R.G. Childhood soy intake and breast cancer risk in Asian American women. Cancer Epidemiol. Biomark. Prev. 2009, 18, 1050-1059. [CrossRef] [PubMed]

339. Wu, A.H.; Wan, P.; Hankin, J.; Tseng, C.C.; Yu, M.C.; Pike, M.C. Adolescent and adult soy intake and risk of breast cancer in Asian-Americans. Carcinogenesis 2002, 23, 1491-1496. [CrossRef] [PubMed]

340. Grosso, G.; Godos, J.; Lamuela-Raventos, R.; Ray, S.; Micek, A.; Pajak, A.; Sciacca, S.; D'Orazio, N.; Del Rio, D.; Galvano, F. A comprehensive meta-analysis on dietary flavonoid and lignan intake and cancer risk: Level of evidence and limitations. Mol. Nutr. Food Res. 2017, 61. [CrossRef] [PubMed]

341. Colonese, F.; La Rosa, V.L.; Laganà, A.S.; Vitale, S.G.; Cortinovis, D.; Bidoli, P. Comment on: “Is there a role for vitamin D in human reproduction?". Horm. Mol. Biol. Clin. Investig. 2017, 29, 37-38. [CrossRef] [PubMed]

342. Laganà, A.S.; Sapia, F.; La Rosa, V.L.; Vitale, S.G. Comment on "Inositols: From physiology to rational therapy in gynecological clinical practice". Expert Opin. Drug Metab. Toxicol. 2016, 12, 1527. [CrossRef] [PubMed]

343. Messina, M. Soy foods, isoflavones, and the health of postmenopausal women. Am. J. Clin. Nutr. 2014, 100, 423S-430S. [CrossRef] [PubMed]

344. Cianci, A.; Colacurci, N.; Paoletti, A.M.; Perino, A.; Cicinelli, E.; Maffei, S.; Di Martino, M.; Daguati, R.; Stomati, M.; Pilloni, M.; et al. Soy isoflavones, inulin, calcium, and vitamin D3 in post-menopausal hot flushes: An observational study. Clin. Exp. Obstet. Gynecol. 2015, 42, 743-745. [PubMed]

345. Husain, D.; Khanna, K.; Puri, S.; Haghighizadeh, M. Supplementation of soy isoflavones improved sex hormones, blood pressure, and postmenopausal symptoms. J. Am. Coll. Nutr. 2015, 34, 42-48. [CrossRef] [PubMed]

346. Schmidt, M.; Arjomand-Wölkart, K.; Birkhäuser, M.H.; Genazzani, A.R.; Gruber, D.M.; Huber, J.; Kölbl, H.; Kreft, S.; Leodolter, S.; Linsberger, D.; et al. Consensus: Soy isoflavones as a first-line approach to the treatment of menopausal vasomotor complaints. Gynecol. Endocrinol. 2016, 32, 427-430. [CrossRef] [PubMed]

347. Taku, K.; Melby, M.K.; Nishi, N.; Omori, T.; Kurzer, M.S. Soy isoflavones for osteoporosis: An evidence-based approach. Maturitas 2011, 70, 333-338. [CrossRef] [PubMed]

348. Pawlowski, J.W.; Martin, B.R.; McCabe, G.P.; McCabe, L.; Jackson, G.S.; Peacock, M.; Barnes, S.; Weaver, C.M. Impact of equol-producing capacity and soy-isoflavone profiles of supplements on bone calcium retention in postmenopausal women: A randomized crossover trial. Am. J. Clin. Nutr. 2015, 102, 695-703. [CrossRef] [PubMed]

349. Marini, H.; Bitto, A.; Altavilla, D.; Burnett, B.P.; Polito, F.; Di Stefano, V.; Minutoli, L.; Atteritano, M.; Levy, R.M.; D'Anna, R.; et al. Breast safety and efficacy of genistein aglycone for postmenopausal bone loss: A follow-up study. J. Clin. Endocrinol. Metab. 2008, 93, 4787-4796. [CrossRef] [PubMed]

350. Brink, E.; Coxam, V.; Robins, S.; Wahala, K.; Cassidy, A.; Branca, F. PHYTOS Investigators Long-term consumption of isoflavone-enriched foods does not affect bone mineral density, bone metabolism, or hormonal status in early postmenopausal women: A randomized, double-blind, placebo controlled study. Am. J. Clin. Nutr. 2008, 87, 761-770. [PubMed]

351. Vupadhyayula, P.M.; Gallagher, J.C.; Templin, T.; Logsdon, S.M.; Smith, L.M. Effects of soy protein isolate on bone mineral density and physical performance indices in postmenopausal women-A 2-year randomized, double-blind, placebo-controlled trial. Menopause 2009, 16, 320-328. [CrossRef] [PubMed]

352. Kenny, A.M.; Mangano, K.M.; Abourizk, R.H.; Bruno, R.S.; Anamani, D.E.; Kleppinger, A.; Walsh, S.J.; Prestwood, K.M.; Kerstetter, J.E. Soy proteins and isoflavones affect bone mineral density in older women: A randomized controlled trial. Am. J. Clin. Nutr. 2009, 90, 234-242. [CrossRef] [PubMed]

353. Atkinson, C.; Compston, J.E.; Day, N.E.; Dowsett, M.; Bingham, S.A. The effects of phytoestrogen isoflavones on bone density in women: A double-blind, randomized, placebo-controlled trial. Am. J. Clin. Nutr. 2004, 79, 326-333. [PubMed]

354. Chen, Y.M.; Ho, S.C.; Lam, S.S.H.; Ho, S.S.S.; Woo, J.L.F. Soy isoflavones have a favorable effect on bone loss in Chinese postmenopausal women with lower bone mass: A double-blind, randomized, controlled trial. J. Clin. Endocrinol. Metab. 2003, 88, 4740-4747. [CrossRef] [PubMed] 
355. Marini, H.; Minutoli, L.; Polito, F.; Bitto, A.; Altavilla, D.; Atteritano, M.; Gaudio, A.; Mazzaferro, S.; Frisina, A.; Frisina, N.; et al. Effects of the phytoestrogen genistein on bone metabolism in osteopenic postmenopausal women: A randomized trial. Ann. Intern. Med. 2007, 146, 839-847. [CrossRef] [PubMed]

356. Morabito, N.; Crisafulli, A.; Vergara, C.; Gaudio, A.; Lasco, A.; Frisina, N.; D’Anna, R.; Corrado, F.; Pizzoleo, M.A.; Cincotta, M.; et al. Effects of genistein and hormone-replacement therapy on bone loss in early postmenopausal women: A randomized double-blind placebo-controlled study. J. Bone Miner. Res. 2002, 17, 1904-1912. [CrossRef] [PubMed]

357. Roughead, Z.K.; Hunt, J.R.; Johnson, L.K.; Badger, T.M.; Lykken, G.I. Controlled substitution of soy protein for meat protein: Effects on calcium retention, bone, and cardiovascular health indices in postmenopausal women. J. Clin. Endocrinol. Metab. 2005, 90, 181-189. [CrossRef] [PubMed]

358. Spence, L.A.; Lipscomb, E.R.; Cadogan, J.; Martin, B.; Wastney, M.E.; Peacock, M.; Weaver, C.M. The effect of soy protein and soy isoflavones on calcium metabolism in postmenopausal women: A randomized crossover study. Am. J. Clin. Nutr. 2005, 81, 916-922. [PubMed]

359. Matthews, V.L.; Knutsen, S.F.; Beeson, W.L.; Fraser, G.E. Soy milk and dairy consumption is independently associated with ultrasound attenuation of the heel bone among postmenopausal women: The Adventist Health Study-2. Nutr. Res. 2011, 31, 766-775. [CrossRef] [PubMed]

360. Chen, M.N.; Lin, C.C.; Liu, C.F. Efficacy of phytoestrogens for menopausal symptoms: A meta-analysis and systematic review. Climacteric J. Int. Menopause Soc. 2015, 18, 260-269. [CrossRef] [PubMed]

361. Clarkson, T.B.; Utian, W.H.; Barnes, S.; Gold, E.B.; Basaria, S.S.; Aso, T.; Kronenberg, F.; Frankenfeld, C.L.; Cline, J.M.; Landgren, B.M.; et al. The role of soy isoflavones in menopausal health: Report of The North American Menopause Society/Wulf H. Utian Translational Science Symposium in Chicago, IL (October 2010). Menopause 2011, 18, 732-753. [CrossRef]

362. Li, L.; Lv, Y.; Xu, L.; Zheng, Q. Quantitative efficacy of soy isoflavones on menopausal hot flashes. Br. J. Clin. Pharmacol. 2015, 79, 593-604. [CrossRef] [PubMed]

363. Jenks, B.H.; Iwashita, S.; Nakagawa, Y.; Ragland, K.; Lee, J.; Carson, W.H.; Ueno, T.; Uchiyama, S. A pilot study on the effects of S-equol compared to soy isoflavones on menopausal hot flash frequency. J. Womens Health 2012, 21, 674-682. [CrossRef] [PubMed]

364. Laganà, A.S.; Vitale, S.G.; Nigro, A.; Sofo, V.; Salmeri, F.M.; Rossetti, P.; Rapisarda, A.M.C.; La Vignera, S.; Condorelli, R.A.; Rizzo, G.; et al. Pleiotropic Actions of Peroxisome Proliferator-Activated Receptors (PPARs) in Dysregulated Metabolic Homeostasis, Inflammation and Cancer: Current Evidence and Future Perspectives. Int. J. Mol. Sci. 2016, 17, 999. [CrossRef] [PubMed]

365. Darling, A.L.; Millward, D.J.; Torgerson, D.J.; Hewitt, C.E.; Lanham-New, S.A. Dietary protein and bone health: A systematic review and meta-analysis. Am. J. Clin. Nutr. 2009, 90, 1674-1692. [CrossRef] [PubMed]

366. Colonese, F.; Laganà, A.S.; Colonese, E.; Sofo, V.; Salmeri, F.M.; Granese, R.; Triolo, O. The pleiotropic effects of vitamin D in gynaecological and obstetric diseases: An overview on a hot topic. BioMed Res. Int. 2015, 2015, 986281. [CrossRef] [PubMed]

367. Institute of Medicine. Dietary Reference Intakes: The Essential Guide to Nutrient Requirements; Otten, J.J., Hellwig, J.P., Meyers, L.D., Eds.; The National Academies Press: Washington, DC, USA, 2006; ISBN 978-0-309-15742-1.

368. Fredlund, K.; Isaksson, M.; Rossander-Hulthén, L.; Almgren, A.; Sandberg, A.S. Absorption of zinc and retention of calcium: Dose-dependent inhibition by phytate. J. Trace Elem. Med. Biol. 2006, 20, 49-57. [CrossRef] [PubMed]

369. Ørgaard, A.; Jensen, L. The effects of soy isoflavones on obesity. Exp. Biol. Med. 2008, 233, 1066-1080. [CrossRef] [PubMed]

370. Muscogiuri, G.; Palomba, S.; Laganà, A.S.; Orio, F. Inositols in the Treatment of Insulin-Mediated Diseases. Int. J. Endocrinol. 2016, 2016, 3058393. [CrossRef] [PubMed]

371. Bhathena, S.J.; Velasquez, M.T. Beneficial role of dietary phytoestrogens in obesity and diabetes. Am. J. Clin. Nutr. 2002, 76, 1191-1201. [PubMed]

372. Paul, C.; Laganà, A.S.; Maniglio, P.; Triolo, O.; Brady, D.M. Inositol's and other nutraceuticals' synergistic actions counteract insulin resistance in polycystic ovarian syndrome and metabolic syndrome: State-of-the-art and future perspectives. Gynecol. Endocrinol. 2016, 32, 431-438. [CrossRef] [PubMed] 
373. Chalvon-Demersay, T.; Azzout-Marniche, D.; Arfsten, J.; Egli, L.; Gaudichon, C.; Karagounis, L.G.; Tomé, D. A Systematic Review of the Effects of Plant Compared with Animal Protein Sources on Features of Metabolic Syndrome. J. Nutr. 2017, 147, 281-292. [CrossRef] [PubMed]

374. Pi-Sunyer, F.X. Glycemic index and disease. Am. J. Clin. Nutr. 2002, 76, 290S-298S. [PubMed]

375. Neacsu, M.; Fyfe, C.; Horgan, G.; Johnstone, A.M. Appetite control and biomarkers of satiety with vegetarian (soy) and meat-based high-protein diets for weight loss in obese men: A randomized crossover trial. Am. J. Clin. Nutr. 2014, 100, 548-558. [CrossRef] [PubMed]

376. Anderson, J.W. Beneficial effects of soy protein consumption for renal function. Asia Pac. J. Clin. Nutr. 2008, 17, 324-328. [PubMed]

377. Lee, Y.B.; Lee, H.J.; Sohn, H.S. Soy isoflavones and cognitive function. J. Nutr. Biochem. 2005, 16, 641-649. [CrossRef] [PubMed]

378. Ryan-Borchers, T.A.; Park, J.S.; Chew, B.P.; McGuire, M.K.; Fournier, L.R.; Beerman, K.A. Soy isoflavones modulate immune function in healthy postmenopausal women. Am. J. Clin. Nutr. 2006, 83, 1118-1125. [PubMed]

379. Cederroth, C.R.; Zimmermann, C.; Nef, S. Soy, phytoestrogens and their impact on reproductive health. Mol. Cell. Endocrinol. 2012, 355, 192-200. [CrossRef] [PubMed]

380. Fernandez-Raudales, D.; Hoeflinger, J.L.; Bringe, N.A.; Cox, S.B.; Dowd, S.E.; Miller, M.J.; Gonzalez de Mejia, E. Consumption of different soymilk formulations differentially affects the gut microbiomes of overweight and obese men. Gut Microbes 2012, 3, 490-500. [CrossRef] [PubMed]

381. Nakatsu, C.H.; Armstrong, A.; Clavijo, A.P.; Martin, B.R.; Barnes, S.; Weaver, C.M. Fecal bacterial community changes associated with isoflavone metabolites in postmenopausal women after soy bar consumption. PLoS ONE 2014, 9, e108924. [CrossRef] [PubMed]

382. Inoguchi, S.; Ohashi, Y.; Narai-Kanayama, A.; Aso, K.; Nakagaki, T.; Fujisawa, T. Effects of non-fermented and fermented soybean milk intake on faecal microbiota and faecal metabolites in humans. Int. J. Food Sci. Nutr. 2012, 63, 402-410. [CrossRef] [PubMed]

383. Lawrence, S.E.; Lopetcharat, K.; Drake, M.A. Preference Mapping of Soymilk with Different U.S. Consumers. J. Food Sci. 2016, 81, S463-S476. [CrossRef] [PubMed]

384. Li, Y.R.; Yun, T.T.; Liu, S.; Qi, W.T.; Zhao, L.Q.; Liu, J.R.; Li, A.K. Analysis of water-soluble bioactive compounds in commonly consumed soymilk in China. J. Food Compos. Anal. 2016, 46, 29-35. [CrossRef]

385. Nakasato, K.; Ono, T.; Ishiguro, T.; Takamatsu, M.; Tsukamoto, C.; Mikami, M. Rapid quantitative analysis of the major components in soymilk using Fourier-transform infrared spectroscopy (FT-IR). Food Sci. Technol. Res. 2004, 10, 137-142. [CrossRef]

386. Hou, J.W.; Yu, R.C.; Chou, C.C. Changes in some components of soymilk during fermentation with bifidobacteria. Food Res. Int. 2000, 33, 393-397. [CrossRef]

387. Piacentini, G.; Peroni, D.; Bessi, E.; Morelli, L. Molecular characterization of intestinal microbiota in infants fed with soymilk. J. Pediatr. Gastroenterol. Nutr. 2010, 51, 71-76. [CrossRef] [PubMed]

388. Hong, H.; Landauer, M.R.; Foriska, M.A.; Ledney, G.D. Antibacterial activity of the soy isoflavone genistein. J. Basic Microbiol. 2006, 46, 329-335. [CrossRef] [PubMed]

389. Wang, Q.; Wang, H.; Xie, M. Antibacterial mechanism of soybean isoflavone on Staphylococcus aureus. Arch. Microbiol. 2010, 192, 893-898. [CrossRef] [PubMed]

390. Clavel, T.; Fallani, M.; Lepage, P.; Levenez, F.; Mathey, J.; Rochet, V.; Sérézat, M.; Sutren, M.; Henderson, G.; Bennetau-Pelissero, C.; et al. Isoflavones and functional foods alter the dominant intestinal microbiota in postmenopausal women. J. Nutr. 2005, 135, 2786-2792. [PubMed]

391. Cheng, I.C.; Shang, H.F.; Lin, T.F.; Wang, T.H.; Lin, H.S.; Lin, S.H. Effect of fermented soy milk on the intestinal bacterial ecosystem. World J. Gastroenterol. 2005, 11, 1225-1227. [CrossRef] [PubMed]

392. Cha, Y.S.; Park, Y.; Lee, M.; Chae, S.W.; Park, K.; Kim, Y.; Lee, H.S. Doenjang, a Korean fermented soy food, exerts antiobesity and antioxidative activities in overweight subjects with the PPAR- $\gamma 2$ C1431T polymorphism: 12-week, double-blind randomized clinical trial. J. Med. Food 2014, 17, 119-127. [CrossRef] [PubMed]

393. Marsh, A.J.; Hill, C.; Ross, R.P.; Cotter, P.D. Fermented beverages with health-promoting potential: Past and future perspectives. Trends Food Sci. Technol. 2014, 38, 113-124. [CrossRef]

394. Parvez, S.; Malik, K.A.; Ah Kang, S.; Kim, H.-Y. Probiotics and their fermented food products are beneficial for health. J. Appl. Microbiol. 2006, 100, 1171-1185. [CrossRef] [PubMed] 
395. Bedani, R.; Pauly-Silveira, N.D.; Roselino, M.N.; de Valdez, G.F.; Rossi, E.A. Effect of fermented soy product on the fecal microbiota of rats fed on a beef-based animal diet. J. Sci. Food Agric. 2010, 90, 233-238. [CrossRef] [PubMed]

396. Lee, S.M.; Han, H.W.; Yim, S.Y. Beneficial effects of soy milk and fiber on high cholesterol diet-induced alteration of gut microbiota and inflammatory gene expression in rats. Food Funct. 2015, 6, 492-500. [CrossRef] [PubMed]

397. Arroyo, G.; Penas, E.; Pedrazuela, A.; Prestamo, G. Intestinal microbiota in rats fed with tofu (soy curd) treated under high pressure. Eur. Food Res. Technol. 2005, 220, 395-400. [CrossRef]

398. Dersjant-Li, Y.; Peisker, M. The impact of soy oligosaccharides on digestion and intestinal health in weaning piglets. Livest. Sci. 2010, 134, 187-189. [CrossRef]

399. Li, T.; Zhong, J.Z.; Wan, J.; Liu, C.M.; Le, B.Y.; Liu, W.; Fu, G.M. Effects of micronized okara dietary fiber on cecal microbiota, serum cholesterol and lipid levels in BALB/c mice. Int. J. Food Sci. Nutr. 2013, 64, 968-973. [CrossRef] [PubMed]

400. Jang, S.E.; Kim, K.A.; Han, M.J.; Kim, D.H. Doenjang, a fermented Korean soybean paste, inhibits lipopolysaccharide production of gut microbiota in mice. J. Med. Food 2014, 17, 67-75. [CrossRef] [PubMed]

401. Cavallini, D.C.U.; Suzuki, J.Y.; Abdalla, D.S.P.; Vendramini, R.C.; Pauly-Silveira, N.D.; Roselino, M.N.; Pinto, R.A.; Rossi, E.A. Influence of a probiotic soy product on fecal microbiota and its association with cardiovascular risk factors in an animal model. Lipids Health Dis. 2011, 10, 126. [CrossRef] [PubMed]

402. Cani, P.D.; Bibiloni, R.; Knauf, C.; Waget, A.; Neyrinck, A.M.; Delzenne, N.M.; Burcelin, R. Changes in gut microbiota control metabolic endotoxemia-induced inflammation in high-fat diet-induced obesity and diabetes in mice. Diabetes 2008, 57, 1470-1481. [CrossRef] [PubMed]

403. McCARRISON, R. The goitrogenic action of soya-bean and ground-nut. Indian J. Med. Res. 1933, 21, $179-181$.

404. Doerge, D.R.; Chang, H.C. Inactivation of thyroid peroxidase by soy isoflavones, in vitro and in vivo. J. Chromatogr. B Analyt. Technol. Biomed. Life Sci. 2002, 777, 269-279. [CrossRef]

405. Messina, M.; Redmond, G. Effects of soy protein and soybean isoflavones on thyroid function in healthy adults and hypothyroid patients: A review of the relevant literature. Thyroid 2006, 16, 249-258. [CrossRef] [PubMed]

406. Bitto, A.; Polito, F.; Atteritano, M.; Altavilla, D.; Mazzaferro, S.; Marini, H.; Adamo, E.B.; D'Anna, R.; Granese, R.; Corrado, F.; et al. Genistein aglycone does not affect thyroid function: Results from a three-year, randomized, double-blind, placebo-controlled trial. J. Clin. Endocrinol. Metab. 2010, 95, 3067-3072. [CrossRef] [PubMed]

407. Sosvorová, L.; Mikšátková, P.; Bičíková, M.; Kaňová, N.; Lapčík, O. The presence of monoiodinated derivates of daidzein and genistein in human urine and its effect on thyroid gland function. Food Chem. Toxicol. 2012, 50, 2774-2779. [CrossRef] [PubMed]

408. De Souza Dos Santos, M.C.; Gonçalves, C.F.L.; Vaisman, M.; Ferreira, A.C.F.; de Carvalho, D.P. Impact of flavonoids on thyroid function. Food Chem. Toxicol. 2011, 49, 2495-2502. [CrossRef] [PubMed]

409. Tonstad, S.; Jaceldo-Siegl, K.; Messina, M.; Haddad, E.; Fraser, G.E. The association between soya consumption and serum thyroid-stimulating hormone concentrations in the Adventist Health Study-2. Public Health Nutr. 2016, 19, 1464-1470. [CrossRef] [PubMed]

410. Shepard, T.H.; Pyne, G.E.; Kirschvink, J.F.; McLean, M.C. Soybean Goiter. N. Engl. J. Med. 1960, 262, 1099-1103. [CrossRef]

411. Van Wyk, J.J.; Arnold, M.B.; Wynn, J.; Pepper, F. The effects of a soybean product on thyroid function in humans. Pediatrics 1959, 24, 752-760. [PubMed]

412. Hydovitz, J.D. Occurrence of goiter in an infant on a soy diet. N. Engl. J. Med. 1960, 262, 351-353. [CrossRef] [PubMed]

413. Marini, H.; Polito, F.; Adamo, E.B.; Bitto, A.; Squadrito, F.; Benvenga, S. Update on genistein and thyroid: An overall message of safety. Front. Endocrinol. 2012, 3. [CrossRef] [PubMed]

414. Conrad, S.C.; Chiu, H.; Silverman, B.L. Soy formula complicates management of congenital hypothyroidism. Arch. Dis. Child. 2004, 89, 37-40. [CrossRef] [PubMed]

415. Liwanpo, L.; Hershman, J.M. Conditions and drugs interfering with thyroxine absorption. Best Pract. Res. Clin. Endocrinol. Metab. 2009, 23, 781-792. [CrossRef] [PubMed]

416. Bennetts, H.W.; Underwood, E.J.; Shier, F.L. A specific breeding problem of sheep on subterranean clover pastures in Western Australia. Aust. Vet. J. 1946, 22, 2-12. [CrossRef] [PubMed] 
417. Shutt, D.A. The effects of plant oestrogens on animal reproduction. Endeavour 1976, 35, 110-113. [CrossRef]

418. Siepmann, T.; Roofeh, J.; Kiefer, F.W.; Edelson, D.G. Hypogonadism and erectile dysfunction associated with soy product consumption. Nutrition 2011, 27, 859-862. [CrossRef] [PubMed]

419. Martinez, J.; Lewi, J.E. An unusual case of gynecomastia associated with soy product consumption. Endocr. Pract. 2008, 14, 415-418. [CrossRef] [PubMed]

420. Messina, M. Soybean isoflavone exposure does not have feminizing effects on men: A critical examination of the clinical evidence. Fertil. Steril. 2010, 93, 2095-2104. [CrossRef] [PubMed]

421. Chavarro, J.E.; Toth, T.L.; Sadio, S.M.; Hauser, R. Soy food and isoflavone intake in relation to semen quality parameters among men from an infertility clinic. Hum. Reprod. 2008, 23, 2584-2590. [CrossRef] [PubMed]

422. Song, G.; Kochman, L.; Andolina, E.; Herko, R.C.; Brewer, K.J.; Lewis, V. Beneficial effects of dietary intake of plant phytoestrogens on semen parameters and sperm DNA integrity in infertile men. Fertil. Steril. 2006, 86, S49. [CrossRef]

423. Mitchell, J.H.; Cawood, E.; Kinniburgh, D.; Provan, A.; Collins, A.R.; Irvine, D.S. Effect of a phytoestrogen food supplement on reproductive health in normal males. Clin. Sci. 2001, 100, 613-618. [CrossRef] [PubMed]

424. Hamilton-Reeves, J.M.; Vazquez, G.; Duval, S.J.; Phipps, W.R.; Kurzer, M.S.; Messina, M.J. Clinical studies show no effects of soy protein or isoflavones on reproductive hormones in men: Results of a meta-analysis. Fertil. Steril. 2010, 94, 997-1007. [CrossRef] [PubMed]

425. National Toxicology Program. Multigenerational reproductive study of genistein (Cas No. 446-72-0) in Sprague-Dawley rats (feed study). Natl. Toxicol. Program Tech. Rep. Ser. 2008, 539, 1-266.

426. Jacobsen, B.K.; Jaceldo-Siegl, K.; Knutsen, S.F.; Fan, J.; Oda, K.; Fraser, G.E. Soy isoflavone intake and the likelihood of ever becoming a mother: The Adventist Health Study-2. Int. J. Womens Health 2014, 6, 377-384. [CrossRef] [PubMed]

427. Bhatia, J.; Greer, F.; American Academy of Pediatrics Committee on Nutrition. Use of soy protein-based formulas in infant feeding. Pediatrics 2008, 121, 1062-1068. [CrossRef] [PubMed]

428. National Toxicology Program. NTP-CERHR monograph on Soy Infant Formula. NTP CERHR Monogr. 2010, $23, \mathrm{i}-661$.

429. Cao, Y.; Calafat, A.M.; Doerge, D.R.; Umbach, D.M.; Bernbaum, J.C.; Twaddle, N.C.; Ye, X.; Rogan, W.J. Isoflavones in urine, saliva, and blood of infants: Data from a pilot study on the estrogenic activity of soy formula. J. Expo. Sci. Environ. Epidemiol. 2009, 19, 223-234. [CrossRef] [PubMed]

430. Setchell, K.D.; Zimmer-Nechemias, L.; Cai, J.; Heubi, J.E. Exposure of infants to phyto-oestrogens from soy-based infant formula. Lancet 1997, 350, 23-27. [CrossRef]

431. Adgent, M.A.; Daniels, J.L.; Rogan, W.J.; Adair, L.; Edwards, L.J.; Westreich, D.; Maisonet, M.; Marcus, M. Early-life soy exposure and age at menarche. Paediatr. Perinat. Epidemiol. 2012, 26, 163-175. [CrossRef] [PubMed]

432. Strom, B.L.; Schinnar, R.; Ziegler, E.E.; Barnhart, K.T.; Sammel, M.D.; Macones, G.A.; Stallings, V.A.; Drulis, J.M.; Nelson, S.E.; Hanson, S.A. Exposure to soy-based formula in infancy and endocrinological and reproductive outcomes in young adulthood. JAMA 2001, 286, 807-814. [CrossRef] [PubMed]

433. Segovia-Siapco, G.; Pribis, P.; Messina, M.; Oda, K.; Sabaté, J. Is soy intake related to age at onset of menarche? A cross-sectional study among adolescents with a wide range of soy food consumption. Nutr. J. 2014, 13, 54. [CrossRef] [PubMed]

434. National Toxicology Program. Toxicology and carcinogenesis studies of genistein (Cas No. 446-72-0) in Sprague-Dawley rats (feed study). Natl. Toxicol. Program Tech. Rep. Ser. 2008, 545, 1-240.

435. Carreau, C.; Flouriot, G.; Bennetau-Pelissero, C.; Potier, M. Respective contribution exerted by AF-1 and AF-2 transactivation functions in estrogen receptor alpha induced transcriptional activity by isoflavones and equol: Consequence on breast cancer cell proliferation. Mol. Nutr. Food Res. 2009, 53, 652-658. [CrossRef] [PubMed]

436. Allred, C.D.; Allred, K.F.; Ju, Y.H.; Virant, S.M.; Helferich, W.G. Soy diets containing varying amounts of genistein stimulate growth of estrogen-dependent (MCF-7) tumors in a dose-dependent manner. Cancer Res. 2001, 61, 5045-5050. [PubMed]

437. Du, M.; Yang, X.; Hartman, J.A.; Cooke, P.S.; Doerge, D.R.; Ju, Y.H.; Helferich, W.G. Low-dose dietary genistein negates the therapeutic effect of tamoxifen in athymic nude mice. Carcinogenesis 2012, 33, 895-901. [CrossRef] [PubMed] 
438. Zamora-Ros, R.; Ferrari, P.; González, C.A.; Tjønneland, A.; Olsen, A.; Bredsdorff, L.; Overvad, K.; Touillaud, M.; Perquier, F.; Fagherazzi, G.; et al. Dietary flavonoid and lignan intake and breast cancer risk according to menopause and hormone receptor status in the European Prospective Investigation into Cancer and Nutrition (EPIC) Study. Breast Cancer Res. Treat. 2013, 139, 163-176. [CrossRef] [PubMed]

439. Speirs, V.; Carder, P.J.; Lane, S.; Dodwell, D.; Lansdown, M.R.J.; Hanby, A.M. Oestrogen receptor beta: What it means for patients with breast cancer. Lancet Oncol. 2004, 5, 174-181. [CrossRef]

440. Wu, A.H.; Spicer, D.; Garcia, A.; Tseng, C.C.; Hovanessian-Larsen, L.; Sheth, P.; Martin, S.E.; Hawes, D.; Russell, C.; MacDonald, H.; et al. Double-Blind Randomized 12-Month Soy Intervention Had No Effects on Breast MRI Fibroglandular Tissue Density or Mammographic Density. Cancer Prev. Res. 2015, 8, 942-951. [CrossRef] [PubMed]

441. Chen, M.; Rao, Y.; Zheng, Y.; Wei, S.; Li, Y.; Guo, T.; Yin, P. Association between soy isoflavone intake and breast cancer risk for pre- and post-menopausal women: A meta-analysis of epidemiological studies. PLoS ONE 2014, 9, e89288. [CrossRef] [PubMed]

442. Travis, R.C.; Allen, N.E.; Appleby, P.N.; Spencer, E.A.; Roddam, A.W.; Key, T.J. A prospective study of vegetarianism and isoflavone intake in relation to breast cancer risk in British women. Int. J. Cancer 2008, 122, 705-710. [CrossRef] [PubMed]

443. Lamartiniere, C.A.; Moore, J.; Holland, M.; Barnes, S. Neonatal genistein chemoprevents mammary cancer. Proc. Soc. Exp. Biol. Med. 1995, 208, 120-123. [CrossRef] [PubMed]

444. Cheftel, J.C. Nutritional effects of extrusion-cooking. Food Chem. 1986, 20, 263-283. [CrossRef]

445. Anderson, R.L.; Wolf, W.J. Compositional changes in trypsin inhibitors, phytic acid, saponins and isoflavones related to soybean processing. J. Nutr. 1995, 125, 581S-588S. [PubMed]

446. Friedman, M. Nutritional consequences of food processing. Forum Nutr. 2003, 56, 350-352. [PubMed]

447. Csáky, I.; Fekete, S. Soybean: Feed quality and safety. Part 1: Biologically active components. A review. Acta Vet. Hung. 2004, 52, 299-313. [CrossRef] [PubMed]

448. Molnár-Perl, I.; Pintér-Szakács, M. Monitoring of Maillard reactions in soy products. Z. Lebensm. Unters. Forsch. 1986, 183, 18-25. [CrossRef] [PubMed]

449. Friedman, M. Biological effects of Maillard browning products that may affect acrylamide safety in food: Biological effects of Maillard products. Adv. Exp. Med. Biol. 2005, 561, 135-156. [CrossRef] [PubMed]

450. Sugawara, E.; Saiga, S.; Kobayashi, A. Relationships between Aroma Components and Sensory Evaluation of Miso. J. Food Sci. Technol. 1992, 39, 1098-1104. [CrossRef]

451. Wang, H.; Jenner, A.M.; Lee, C.Y.J.; Shui, G.; Tang, S.Y.; Whiteman, M.; Wenk, M.R.; Halliwell, B. The identification of antioxidants in dark soy sauce. Free Radic. Res. 2007, 41, 479-488. [CrossRef] [PubMed]

452. Ginting, E.; Arcot, J. High-performance liquid chromatographic determination of naturally occurring folates during tempe preparation. J. Agric. Food Chem. 2004, 52, 7752-7758. [CrossRef] [PubMed]

453. Hammes, W.P. Fermentation of non-dairy foods. Food Biotechnol. 1991, 5, 293-303. [CrossRef]

454. Setchell, K.D.; Welsh, M.B.; Lim, C.K. High-performance liquid chromatographic analysis of phytoestrogens in soy protein preparations with ultraviolet, electrochemical and thermospray mass spectrometric detection. J. Chromatogr. 1987, 386, 315-323. [CrossRef]

455. Heller, K.J. Probiotic bacteria in fermented foods: Product characteristics and starter organisms. Am. J. Clin. Nutr. 2001, 73, 374S-379S. [PubMed]

456. Council Regulation (EEC) No. 1898/87 of 2 July 1987 on the Protection of Designations Used in Marketing of Milk and Milk Products. Available online: http:/ / eur-lex.europa.eu/legal-content/EN/TXT/?uri=celex\% 3A31987R1898 (accessed on 9 September 2017).

457. Klemola, T.; Vanto, T.; Juntunen-Backman, K.; Kalimo, K.; Korpela, R.; Varjonen, E. Allergy to soy formula and to extensively hydrolyzed whey formula in infants with cow's milk allergy: A prospective, randomized study with a follow-up to the age of 2 years. J. Pediatr. 2002, 140, 219-224. [CrossRef] [PubMed]

458. Zeiger, R.S.; Sampson, H.A.; Bock, S.A.; Burks, A.W.; Harden, K.; Noone, S.; Martin, D.; Leung, S.; Wilson, G. Soy allergy in infants and children with IgE-associated cow's milk allergy. J. Pediatr. 1999, 134, 614-622. [CrossRef]

459. Allen, K.J.; Davidson, G.P.; Day, A.S.; Hill, D.J.; Kemp, A.S.; Peake, J.E.; Prescott, S.L.; Shugg, A.; Sinn, J.K.H.; Heine, R.G. Management of cow's milk protein allergy in infants and young children: An expert panel perspective. J. Paediatr. Child Health 2009, 45, 481-486. [CrossRef] [PubMed] 
460. Ho, H.M.; Chen, R.Y.; Leung, L.K.; Chan, F.L.; Huang, Y.; Chen, Z.-Y. Difference in flavonoid and isoflavone profile between soybean and soy leaf. Biomed. Pharmacother. 2002, 56, 289-295. [CrossRef]

461. Reinli, K.; Block, G. Phytoestrogen content of foods-A compendium of literature values. Nutr. Cancer 1996, 26, 123-148. [CrossRef] [PubMed]

462. Liggins, J.; Bluck, L.J.; Runswick, S.; Atkinson, C.; Coward, W.A.; Bingham, S.A. Daidzein and genistein contents of vegetables. Br. J. Nutr. 2000, 84, 717-725. [PubMed]

463. Setchell, K.D.R.; Cole, S.J. Variations in isoflavone levels in soy foods and soy protein isolates and issues related to isoflavone databases and food labeling. J. Agric. Food Chem. 2003, 51, 4146-4155. [CrossRef] [PubMed]

464. Franke, A.A.; Hankin, J.H.; Yu, M.C.; Maskarinec, G.; Low, S.H.; Custer, L.J. Isoflavone levels in soy foods consumed by multiethnic populations in Singapore and Hawaii. J. Agric. Food Chem. 1999, 47, 977-986. [CrossRef] [PubMed]

465. Haron, H.; Ismail, A.; Azlan, A.; Shahar, S.; Peng, L.S. Daidzein and genestein contents in tempeh and selected soy products. Food Chem. 2009, 115, 1350-1356. [CrossRef]

466. Simonne, A.H.; Smith, M.; Weaver, D.B.; Vail, T.; Barnes, S.; Wei, C.I. Retention and changes of soy isoflavones and carotenoids in immature soybean seeds (Edamame) during processing. J. Agric. Food Chem. 2000, 48, 6061-6069. [CrossRef] [PubMed]

467. Cassidy, A. Factors affecting the bioavailability of soy isoflavones in humans. J. AOAC Int. 2006, 89, 1182-1188. [PubMed]

468. Chen, T.R.; Wei, Q.K. Analysis of bioactive aglycone isoflavones in soybean and soybean products. Nutr. Food Sci. 2008, 38, 540-547. [CrossRef]

469. Astuti, M.; Meliala, A.; Dalais, F.S.; Wahlqvist, M.L. Tempe, a nutritious and healthy food from Indonesia. Asia Pac. J. Clin. Nutr. 2000, 9, 322-325. [CrossRef] [PubMed]

470. Ferreira, M.P.; de Oliveira, M.C.N.; Mandarino, J.M.G.; da Silva, J.B.; Ida, E.I.; Carrão-Panizzi, M.C. Changes in the isoflavone profile and in the chemical composition of tempeh during processing and refrigeration. Pesq. Agropecu. Bras. 2011, 46, 1555-1561. [CrossRef]

471. Allred, C.D.; Allred, K.F.; Ju, Y.H.; Goeppinger, T.S.; Doerge, D.R.; Helferich, W.G. Soy processing influences growth of estrogen-dependent breast cancer tumors. Carcinogenesis 2004, 25, 1649-1657. [CrossRef] [PubMed]

472. Lin, S.; Huff, H.E.; Hsieh, F. Texture and Chemical Characteristics of Soy Protein Meat Analog Extruded at High Moisture. J. Food Sci. 2000, 65, 264-269. [CrossRef]

473. Lin, S.; Huff, H.E.; Hsieh, F. Extrusion Process Parameters, Sensory Characteristics, and Structural Properties of a High Moisture Soy Protein Meat Analog. J. Food Sci. 2002, 67, 1066-1072. [CrossRef]

474. Liu, K.S.; Hsieh, F.H. Protein-Protein Interactions in High Moisture-Extruded Meat Analogs and Heat-Induced Soy Protein Gels. J. Am. Oil Chem. Soc. 2007, 84, 741-748. [CrossRef]

475. Camire, M.E.; Camire, A.; Krumhar, K. Chemical and nutritional changes in foods during extrusion. Crit. Rev. Food Sci. Nutr. 1990, 29, 35-57. [CrossRef] [PubMed]

476. Marsmana, G.J.P.; Gruppen, H.; van Zuilichem, D.J.; Resink, J.W.; Voragen, A.G.J. The influence of screw configuration on the in vitro digestibility and protein solubility of soybean and rapeseed meals. J. Food Eng. 1995, 26, 13-28. [CrossRef]

477. MacDonald, R.S.; Pryzbyszewski, J.; Hsieh, F.H. Soy protein isolate extruded with high moisture retains high nutritional quality. J. Agric. Food Chem. 2009, 57, 3550-3555. [CrossRef] [PubMed]

478. Hegarty, P.V.J.; Ahn, P.C. Nutritional comparisons between a soy-based meat analog and beef in the unheated and heated states. J. Food Sci. 1976, 41, 1133-1136. [CrossRef]

479. Burton, J.W. Recent Developments in Breeding Soybeans for Improved Oil Quality. Lipid Fett 1991, 93, 121-128. [CrossRef]

480. Yuan, S.; Chang, S.K.C.; Liu, Z.; Xu, B. Elimination of trypsin inhibitor activity and beany flavor in soy milk by consecutive blanching and ultrahigh-temperature (UHT) processing. J. Agric. Food Chem. 2008, 56, 7957-7963. [CrossRef] [PubMed]

481. De Carneiro, J.D.S.; Minim, V.P.R.; Deliza, R.; Silva, C.H.O.; Carneiro, J.C.S.; Leão, F.P. Labelling effects on consumer intention to purchase for soybean oil. Food Qual. Prefer. 2005, 16, 275-282. [CrossRef]

482. Kuhnle, G.G.C.; Dell'Aquila, C.; Aspinall, S.M.; Runswick, S.A.; Mulligan, A.A.; Bingham, S.A. Phytoestrogen content of foods of animal origin: Dairy products, eggs, meat, fish, and seafood. J. Agric. Food Chem. 2008, 56, 10099-10104. [CrossRef] [PubMed] 
483. Wang, H.J.; Murphy, P.A. Mass Balance Study of Isoflavones during Soybean Processing. J. Agric. Food Chem. 1996, 44, 2377-2383. [CrossRef]

484. Pandjaitan, N.; Hettiarachchy, N.; Ju, Z.Y.; Crandall, P.; Sneller, C.; Dombek, D. Evaluation of Genistin and Genistein Contents in Soybean Varieties and Soy Protein Concentrate Prepared with 3 Basic Methods. J. Food Sci. 2000, 65, 399-402. [CrossRef]

485. Wiseman, H.; Casey, K.; Clarke, D.B.; Barnes, K.A.; Bowey, E. Isoflavone aglycon and glucoconjugate content of high- and low-soy U.K. foods used in nutritional studies. J. Agric. Food Chem. 2002, 50, 1404-1410. [CrossRef] [PubMed]

486. Ritchie, M.R.; Cummings, J.H.; Morton, M.S.; Michael Steel, C.; Bolton-Smith, C.; Riches, A.C. A newly constructed and validated isoflavone database for the assessment of total genistein and daidzein intake. Br. J. Nutr. 2006, 95, 204-213. [CrossRef] [PubMed]

487. Hutabarat, L.S.; Greenfield, H.; Mulholland, M. Isoflavones and Coumestrol in Soybeans and Soybean Products from Australia and Indonesia. J. Food Compos. Anal. 2001, 14, 43-58. [CrossRef]

488. Horn-Ross, P.L.; Barnes, S.; Lee, M.; Coward, L.; Mandel, J.E.; Koo, J.; John, E.M.; Smith, M. Assessing phytoestrogen exposure in epidemiologic studies: Development of a database (United States). Cancer Causes Control 2000, 11, 289-298. [CrossRef] [PubMed]

489. Pillow, P.C.; Duphorne, C.M.; Chang, S.; Contois, J.H.; Strom, S.S.; Spitz, M.R.; Hursting, S.D. Development of a database for assessing dietary phytoestrogen intake. Nutr. Cancer 1999, 33, 3-19. [CrossRef] [PubMed]

490. Alezandro, M.R.; Granato, D.; Lajolo, F.M.; Genovese, M.I. Nutritional aspects of second generation soy foods. J. Agric. Food Chem. 2011, 59, 5490-5497. [CrossRef] [PubMed]

491. Genovese, M.I.; Barbosa, A.C.L.; Pinto, M.D.S.; Lajolo, F.M. Commercial soy protein ingredients as isoflavone sources for functional foods. Plant Foods Hum. Nutr. 2007, 62, 53-58. [CrossRef] [PubMed]

492. Kiely, M.; Faughnan, M.; Wähälä, K.; Brants, H.; Mulligan, A. Phyto-oestrogen levels in foods: The design and construction of the VENUS database. Br. J. Nutr. 2003, 89, S19-S23. [CrossRef] [PubMed]

493. Park, M.K.; Song, Y.; Joung, H.; Li, S.J.; Paik, H.Y. Establishment of an isoflavone database for usual Korean foods and evaluation of isoflavone intake among Korean children. Asia Pac. J. Clin. Nutr. 2007, 16, 129-139. [PubMed]

494. Thompson, L.U.; Boucher, B.A.; Liu, Z.; Cotterchio, M.; Kreiger, N. Phytoestrogen content of foods consumed in Canada, including isoflavones, lignans, and coumestan. Nutr. Cancer 2006, 54, 184-201. [CrossRef] [PubMed]

495. Jackson, C.J.C.; Dini, J.P.; Lavandier, C.; Rupasinghe, H.P.V.; Faulkner, H.; Poysa, V.; Buzzell, D.; DeGrandis, S. Effects of processing on the content and composition of isoflavones during manufacturing of soy beverage and tofu. Process Biochem. 2002, 37, 1117-1123. [CrossRef]

496. Uzzan, M.; Nechrebeki, J.; Labuza, T.P. Thermal and storage stability of nutraceuticals in a milk beverage dietary supplement. J. Food Sci. 2007, 72, E109-E114. [CrossRef] [PubMed]

497. Xu, B.; Chang, S.K.C. Total phenolics, phenolic acids, isoflavones, and anthocyanins and antioxidant properties of yellow and black soybeans as affected by thermal processing. J. Agric. Food Chem. 2008, 56, 7165-7175. [CrossRef] [PubMed]

498. White, L.; Petrovitch, H.; Ross, G.W.; Masaki, K. 487 Association of mid-life consumption of tofu with late life cognitive impairment and dementia: The Honolulu-Asia Aging Study. Neurobiol. Aging 1996, 17, S121. [CrossRef]

499. White, L.R.; Petrovitch, H.; Ross, G.W.; Masaki, K.; Hardman, J.; Nelson, J.; Davis, D.; Markesbery, W. Brain aging and midlife tofu consumption. J. Am. Coll. Nutr. 2000, 19, 242-255. [CrossRef] [PubMed]

500. File, S.E.; Jarrett, N.; Fluck, E.; Duffy, R.; Casey, K.; Wiseman, H. Eating soya improves human memory. Psychopharmacology 2001, 157, 430-436. [CrossRef] [PubMed]

501. Levis, S.; Strickman-Stein, N.; Ganjei-Azar, P.; Xu, P.; Doerge, D.R.; Krischer, J. Soy isoflavones in the prevention of menopausal bone loss and menopausal symptoms: A randomized, double-blind trial. Arch. Intern. Med. 2011, 171, 1363-1369. [CrossRef] [PubMed]

502. EFSA Panel on Food Additives and Nutrient Sources added to Food (ANS). Risk assessment for peri- and post-menopausal women taking food supplements containing isolated isoflavones: Safety of isoflavones from food supplements in menopausal women. EFSA J. 2015, 13, 4246. [CrossRef]

503. Messina, M. Post-Diagnosis Soy Isoflavone Intake Is Not Harmful to Women with Breast Cancer. Breast Dis. 2015, 26, 193-197. [CrossRef] 
504. Chi, F.; Wu, R.; Zeng, Y.C.; Xing, R.; Liu, Y.; Xu, Z.G. Post-diagnosis soy food intake and breast cancer survival: A meta-analysis of cohort studies. Asian Pac. J. Cancer Prev. 2013, 14, 2407-2412. [CrossRef] [PubMed]

505. Boyapati, S.M.; Shu, X.; Ruan, Z.X.; Dai, Q.; Cai, Q.; Gao, Y.; Zheng, W. Soyfood intake and breast cancer survival: A followup of the Shanghai Breast Cancer Study. Breast Cancer Res. Treat. 2005, 92, 11-17. [CrossRef] [PubMed]

506. Fink, B.N.; Steck, S.E.; Wolff, M.S.; Britton, J.A.; Kabat, G.C.; Gaudet, M.M.; Abrahamson, P.E.; Bell, P.; Schroeder, J.C.; Teitelbaum, S.L.; et al. Dietary flavonoid intake and breast cancer survival among women on Long Island. Cancer Epidemiol. Biomark. Prev. 2007, 16, 2285-2292. [CrossRef] [PubMed]

507. Guha, N.; Kwan, M.L.; Quesenberry, C.P.; Weltzien, E.K.; Castillo, A.L.; Caan, B.J. Soy isoflavones and risk of cancer recurrence in a cohort of breast cancer survivors: The Life After Cancer Epidemiology study. Breast Cancer Res. Treat. 2009, 118, 395-405. [CrossRef] [PubMed]

508. Nechuta, S.J.; Caan, B.J.; Chen, W.Y.; Lu, W.; Chen, Z.; Kwan, M.L.; Flatt, S.W.; Zheng, Y.; Zheng, W.; Pierce, J.P.; et al. Soy food intake after diagnosis of breast cancer and survival: An in-depth analysis of combined evidence from cohort studies of US and Chinese women. Am. J. Clin. Nutr. 2012, 96, 123-132. [CrossRef] [PubMed]

509. Kang, X.; Zhang, Q.; Wang, S.; Huang, X.; Jin, S. Effect of soy isoflavones on breast cancer recurrence and death for patients receiving adjuvant endocrine therapy. CMAJ 2010, 182, 1857-1862. [CrossRef] [PubMed]

510. Ruhräh, J. The Soy bean in Infant Feeding: Preliminary Report. Arch. Pediatr. 1909, 26, 496-501.

511. Zoppi, G.; Gasparini, R.; Mantovanelli, F.; Gobio-Casali, L.; Astolfi, R.; Crovari, P. Diet and antibody response to vaccinations in healthy infants. Lancet 1983, 2, 11-14. [CrossRef]

512. Zoppi, G.; Gerosa, F.; Pezzini, A.; Bassani, N.; Rizzotti, P.; Bellini, P.; Todeschini, G.; Zamboni, G.; Vazzoler, G.; Tridente, G. Immunocompetence and dietary protein intake in early infancy. J. Pediatr. Gastroenterol. Nutr. 1982, 1, 175-182. [CrossRef] [PubMed]

513. Zoppi, G.; Zamboni, G.; Bassani, N.; Vazzoler, G. Gammaglobulin level and soy-protein intake in early infancy. Eur. J. Pediatr. 1979, 131, 61-69. [CrossRef] [PubMed]

514. Businco, L.; Bruno, G.; Grandolfo, M.E.; Novello, F.; Fiore, L.; Amato, C. Response to poliovirus immunization and type of feeding in babies of atopic families. Pediatr. Allergy Immunol. 1990, 1, 60-63. [CrossRef]

515. American Academy of Pediatrics; Committee on Nutrition. Soy protein-based formulas: Recommendations for use in infant feeding. Pediatrics 1998, 101, 148-153.

516. Rossen, L.M.; Simon, A.E.; Herrick, K.A. Types of Infant Formulas Consumed in the United States. Clin. Pediatr. 2016, 55, 278-285. [CrossRef] [PubMed]

517. Gartne, L.M.; Morton, J.; Lawrence, R.A.; Naylor, A.J.; O’Hare, D.; Schanler, R.J.; Eidelman, A. IBreastfeeding and the use of human milk. Pediatrics 2012, 129, e827-e841. [CrossRef]

518. EFSA Panel on Dietetic Products, Nutrition and Allergies (NDA). Scientific Opinion on the essential composition of infant and follow-on formulae: Essential composition of infant and follow-on formulae. EFSA J. 2014, 12, 3760. [CrossRef]

519. The Australian College of Pediatrics. Position statement: soy protein formula. J. Paediatr. Child Health 1998, 34, 318-319.

520. Andres, A.; Cleves, M.A.; Bellando, J.B.; Pivik, R.T.; Casey, P.H.; Badger, T.M. Developmental status of 1-year-old infants fed breast milk, cow's milk formula, or soy formula. Pediatrics 2012, 129, 1134-1140. [CrossRef] [PubMed]

521. Lasekan, J.B.; Ostrom, K.M.; Jacobs, J.R.; Blatter, M.M.; Ndife, L.I.; Gooch, W.M.; Cho, S. Growth of newborn, term infants fed soy formulas for 1 year. Clin. Pediatr. 1999, 38, 563-571. [CrossRef] [PubMed]

522. Churella, H.R.; Borschel, M.W.; Thomas, M.R.; Breen, M.; Jacobs, J. Growth and protein status of term infants fed soy protein formulas differing in protein content. J. Am. Coll. Nutr. 1994, 13, 262-267. [CrossRef] [PubMed]

523. Hillman, L.S.; Chow, W.; Salmons, S.S.; Weaver, E.; Erickson, M.; Hansen, J. Vitamin D metabolism, mineral homeostasis, and bone mineralization in term infants fed human milk, cow milk-based formula, or soy-based formula. J. Pediatr. 1988, 112, 864-874. [CrossRef]

524. Mimouni, F.; Campaigne, B.; Neylan, M.; Tsang, R.C. Bone mineralization in the first year of life in infants fed human milk, cow-milk formula, or soy-based formula. J. Pediatr. 1993, 122, 348-354. [CrossRef] 
525. Venkataraman, P.S.; Luhar, H.; Neylan, M.J. Bone mineral metabolism in full-term infants fed human milk, cow milk-based, and soy-based formulas. Am. J. Dis. Child. 1992, 146, 1302-1305. [CrossRef] [PubMed]

526. Klein, K.O. Isoflavones, soy-based infant formulas, and relevance to endocrine function. Nutr. Rev. 1998, 56, 193-204. [CrossRef] [PubMed]

527. Ronis, M.J.; Little, J.M.; Barone, G.W.; Chen, G.; Radominska-Pandya, A.; Badger, T.M. Sulfation of the isoflavones genistein and daidzein in human and rat liver and gastrointestinal tract. J. Med. Food 2006, 9, 348-355. [CrossRef] [PubMed]

528. Businco, L.; Bruno, G.; Giampietro, P.G.; Furcolo, G.; Antoniazzi, F. Absence of Oestrogen Hormonal Effects in Long-Term Soy Formula Fed Children. Pediatr. Res. 1999, 45, 8A. [CrossRef]

529. Vandenplas, Y.; Castrellon, P.G.; Rivas, R.; Gutiérrez, C.J.; Garcia, L.D.; Jimenez, J.E.; Anzo, A.; Hegar, B.; Alarcon, P. Safety of soya-based infant formulas in children. Br. J. Nutr. 2014, 111, 1340-1360. [CrossRef] [PubMed]

530. Jing, H.; Pivik, R.T.; Gilchrist, J.M.; Badger, T.M. No difference indicated in electroencephalographic power spectral analysis in 3- and 6-month-old infants fed soy- or milk-based formula. Matern. Child. Nutr. 2008, 4, 136-145. [CrossRef] [PubMed]

531. Gilchrist, J.M.; Wiggins, P.; Brackenbury, J.; Worthen, A.; Crook, T.; Brodie, M.; Badger, T.M. Body composition among infants fed breast milk, milk-based formula, or soy-based formula Preliminary data from the Beginnings study. FASEB J. 2004, 18, 729-730.

532. Andres, A.; Smith, S.A.; Badger, T.M.; Gilchrist, J.M. Bone mineralization and vitamin D/calcium intake of infants fed breast-milk, milk-based formula or soy-based formula. FASEB J. 2008, 22. [CrossRef]

533. Badger, T.M.; Ronis, M.J.J.; Simmen, R.C.M.; Simmen, F.A. Soy protein isolate and protection against cancer. J. Am. Coll. Nutr. 2005, 24, 146S-149S. [CrossRef] [PubMed]

534. Irvine, C.H.; Shand, N.; Fitzpatrick, M.G.; Alexander, S.L. Daily intake and urinary excretion of genistein and daidzein by infants fed soy- or dairy-based infant formulas. Am. J. Clin. Nutr. 1998, 68, 1462S-1465S. [PubMed]

535. Setchell, K.D.R.; Brown, N.M.; Zimmer-Nechemias, L.; Brashear, W.T.; Wolfe, B.E.; Kirschner, A.S.; Heubi, J.E. Evidence for lack of absorption of soy isoflavone glycosides in humans, supporting the crucial role of intestinal metabolism for bioavailability. Am. J. Clin. Nutr. 2002, 76, 447-453. [PubMed]

536. Franke, A.A.; Custer, L.J.; Tanaka, Y. Isoflavones in human breast milk and other biological fluids. Am. J. Clin. Nutr. 1998, 68, 1466S-1473S. [PubMed]

537. Jochum, F.; Alteheld, B.; Meinardus, P.; Dahlinger, N.; Nomayo, A.; Stehle, P. Mothers' Consumption of Soy Drink But Not Black Tea Increases the Flavonoid Content of Term Breast Milk: A Pilot Randomized, Controlled Intervention Study. Ann. Nutr. Metab. 2017, 70, 147-153. [CrossRef] [PubMed]

538. Franke, A.A.; Halm, B.M.; Custer, L.J.; Tatsumura, Y.; Hebshi, S. Isoflavones in breastfed infants after mothers consume soy. Am. J. Clin. Nutr. 2006, 84, 406-413. [PubMed]

539. Sampson, H.A. Food sensitivity and the pathogenesis of atopic dermatitis. J. R. Soc. Med. 1997, 90, 2-8. [CrossRef] [PubMed]

540. Heine, R.G. Gastroesophageal reflux disease, colic and constipation in infants with food allergy. Curr. Opin. Allergy Clin. Immunol. 2006, 6, 220-225. [CrossRef] [PubMed]

541. Rozenfeld, P.; Docena, G.H.; Añón, M.C.; Fossati, C.A. Detection and identification of a soy protein component that cross-reacts with caseins from cow's milk. Clin. Exp. Immunol. 2002, 130, 49-58. [CrossRef] [PubMed]

542. Sicherer, S.H. Food protein-induced enterocolitis syndrome: Case presentations and management lessons. J. Allergy Clin. Immunol. 2005, 115, 149-156. [CrossRef] [PubMed]

543. Bock, S.A. Prospective appraisal of complaints of adverse reactions to foods in children during the first 3 years of life. Pediatrics 1987, 79, 683-688. [PubMed]

544. Vierk, K.A.; Koehler, K.M.; Fein, S.B.; Street, D.A. Prevalence of self-reported food allergy in American adults and use of food labels. J. Allergy Clin. Immunol. 2007, 119, 1504-1510. [CrossRef] [PubMed]

545. Greenhawt, M.J.; Singer, A.M.; Baptist, A.P. Food allergy and food allergy attitudes among college students. J. Allergy Clin. Immunol. 2009, 124, 323-327. [CrossRef] [PubMed]

546. Ostblom, E.; Lilja, G.; Pershagen, G.; van Hage, M.; Wickman, M. Phenotypes of food hypersensitivity and development of allergic diseases during the first 8 years of life. Clin. Exp. Allergy J. Br. Soc. Allergy Clin. Immunol. 2008, 38, 1325-1332. [CrossRef] [PubMed] 
547. Ostblom, E.; Wickman, M.; van Hage, M.; Lilja, G. Reported symptoms of food hypersensitivity and sensitization to common foods in 4-year-old children. Acta Paediatr. 2008, 97, 85-90. [CrossRef] [PubMed]

548. Young, E.; Stoneham, M.D.; Petruckevitch, A.; Barton, J.; Rona, R. A population study of food intolerance. Lancet 1994, 343, 1127-1130. [CrossRef]

549. Brugman, E.; Meulmeester, J.F.; Spee-van der Wekke, A.; Beuker, R.J.; Radder, J.J.; Verloove-Vanhorick, S.P. Prevalence of self-reported food hypersensitivity among school children in The Netherlands. Eur. J. Clin. Nutr. 1998, 52, 577-581. [CrossRef] [PubMed]

550. Emmett, S.E.; Angus, F.J.; Fry, J.S.; Lee, P.N. Perceived prevalence of peanut allergy in Great Britain and its association with other atopic conditions and with peanut allergy in other household members. Allergy 1999, 54, 380-385. [CrossRef] [PubMed]

551. Kristjansson, I.; Ardal, B.; Jonsson, J.S.; Sigurdsson, J.A.; Foldevi, M.; Björkstén, B. Adverse reactions to food and food allergy in young children in Iceland and Sweden. Scand. J. Prim. Health Care 1999, 17, 30-34. [CrossRef] [PubMed]

552. Schäfer, T.; Böhler, E.; Ruhdorfer, S.; Weigl, L.; Wessner, D.; Heinrich, J.; Filipiak, B.; Wichmann, H.E.; Ring, J. Epidemiology of food allergy/food intolerance in adults: Associations with other manifestations of atopy. Allergy 2001, 56, 1172-1179. [CrossRef] [PubMed]

553. Song, Y.-S.; Frias, J.; Martinez-Villaluenga, C.; Vidal-Valdeverde, C.; de Mejia, E.G. Immunoreactivity reduction of soybean meal by fermentation, effect on amino acid composition and antigenicity of commercial soy products. Food Chem. 2008, 108, 571-581. [CrossRef] [PubMed]

554. Hefle, S.L.; Lambrecht, D.M.; Nordlee, J.A. Soy sauce retains allergenicity through the fermentation/production process. J. Allergy Clin. Immunol. 2005, 115, S32. [CrossRef]

555. Kilgallen, I.; Gibney, M.J. Parental perception of food allergy or intolerance in children under 4 years of age. J. Hum. Nutr. Diet. 1996, 9, 473-478. [CrossRef]

556. Chin, B.; Chan, E.S.; Goldman, R.D. Early exposure to food and food allergy in children. Can. Fam. Phys. 2014, 60, 338-339.

557. Fleischer, D.M.; Sicherer, S.; Greenhawt, M.; Campbell, D.; Chan, E.; Muraro, A.; Halken, S.; Katz, Y.; Ebisawa, M.; Eichenfield, L.; et al. Consensus Communication on Early Peanut Introduction and Prevention of Peanut Allergy in High-Risk Infants. Pediatr. Dermatol. 2016, 33, 103-106. [CrossRef] [PubMed]

558. Schyver, T.; Smith, C. Reported attitudes and beliefs toward soy food consumption of soy consumers versus nonconsumers in natural foods or mainstream grocery stores. J. Nutr. Educ. Behav. 2005, 37, 292-299. [CrossRef]

559. Russin, T.A.; Boye, J.I.; Arcand, Y.; Rajamohamed, S.H. Alternative Techniques for Defatting Soy: A Practical Review. Food Bioprocess Technol. 2011, 4, 200-223. [CrossRef]

560. Lazor, K.; Chapman, N.; Levine, E. Soy goes to school: Acceptance of healthful, vegetarian options in Maryland middle school lunches. J. Sch. Health 2010, 80, 200-206. [CrossRef] [PubMed]

561. Reilly, J.K.; Lanou, A.J.; Barnard, N.D.; Seidl, K.; Green, A.A. Acceptability of soymilk as a calcium-rich beverage in elementary school children. J. Am. Diet. Assoc. 2006, 106, 590-593. [CrossRef] [PubMed]

562. Endres, J.; Barter, S.; Theodora, P.; Welch, P. Soy-enhanced lunch acceptance by preschoolers. J. Am. Diet. Assoc. 2003, 103, 346-351. [CrossRef] [PubMed]

563. Genovese, M.I.; Lajolo, F.M. Isoflavones in soy-based foods consumed in Brazil: Levels, distribution, and estimated intake. J. Agric. Food Chem. 2002, 50, 5987-5993. [CrossRef] [PubMed]

564. Pinto, M.d.S.; Lajolo, F.M.; Genovese, M.I. Effect of storage temperature and water activity on the content and profile of isoflavones, antioxidant activity, and in vitro protein digestibility of soy protein isolates and defatted soy flours. J. Agric. Food Chem. 2005, 53, 6340-6346. [CrossRef] [PubMed]

565. Carpenter, J.; Gass, M.L.; Maki, P.M.; Newton, K.M.; Pinkerton, J.V.; Taylor, M.; Utian, W.H.; Schnatz, P.F.; Kaunitz, A.M.; Shapiro, M.; et al. Nonhormonal management of menopause-associated vasomotor symptoms: 2015 position statement of The North American Menopause Society. Menopause 2015, 22, 1155-1174. [CrossRef]

566. Rock, C.L.; Doyle, C.; Demark-Wahnefried, W.; Meyerhardt, J.; Courneya, K.S.; Schwartz, A.L.; Bandera, E.V.; Hamilton, K.K.; Grant, B.; McCullough, M.; et al. Nutrition and physical activity guidelines for cancer survivors. CA Cancer J. Clin. 2012, 62, 243-274. [CrossRef] [PubMed] 
567. American Institute for Cancer Research (AICR). Soy is Safe for Breast Cancer Survivors. Available online: http://www.aicr.org/press/press-releases/soy-safe-breast-cancer-survivors.html (accessed on 10 September 2017).

568. World Cancer Research Fund International (WCRF). Breast cancer survivors. Available online: http://www. wcrf.org/int/research-we-fund/continuous-update-project-findings-reports/breast-cancer-survivors (accessed on 10 September 2017).

569. Erdman, J.W.; Badger, T.M.; Lampe, J.W.; Setchell, K.D.R.; Messina, M. Not all soy products are created equal: Caution needed in interpretation of research results. J. Nutr. 2004, 134, 1229S-1233S. [PubMed]

570. D'Adamo, C.R.; Sahin, A. Soy foods and supplementation: A review of commonly perceived health benefits and risks. Altern. Ther. Health Med. 2014, 20, 39-51. [PubMed]

571. Valtueña, S.; Cashman, K.; Robins, S.P.; Cassidy, A.; Kardinaal, A.; Branca, F. Investigating the role of natural phyto-oestrogens on bone health in postmenopausal women. Br. J. Nutr. 2003, 89, S87-S99. [CrossRef] [PubMed]

572. Messina, M.J.; Wood, C.E. Soy isoflavones, estrogen therapy, and breast cancer risk: Analysis and commentary. Nutr. J. 2008, 7, 17. [CrossRef] [PubMed]

573. Ridout, C.L.; Wharf, S.G.; Price, K.R.; Johnson, I.T.; Fenwick, G.R. UK mean daily intakes of saponins-intestine-permeabilizing factors in legumes. Food Sci. Nutr. 1988, 42, 111-116. [CrossRef]

574. Demonty, I.; Lamarche, B.; Jones, P.J.H. Role of isoflavones in the hypocholesterolemic effect of soy. Nutr. Rev. 2003, 61, 189-203. [CrossRef] [PubMed]

575. Laganà, A.S.; Rossetti, P.; Buscema, M.; La Vignera, S.; Condorelli, R.A.; Gullo, G.; Granese, R.; Triolo, O. Metabolism and Ovarian Function in PCOS Women: A Therapeutic Approach with Inositols. Int. J. Endocrinol. 2016, 2016, 6306410. [CrossRef] [PubMed]

576. Muscogiuri, G.; Palomba, S.; Laganà, A.S.; Orio, F. Current Insights Into Inositol Isoforms, Mediterranean and Ketogenic Diets for Polycystic Ovary Syndrome: From Bench to Bedside. Curr. Pharm. Des. 2016, 22, 5554-5557. [CrossRef] [PubMed]

577. Laganà, A.S.; Rossetti, P.; Sapia, F.; Chiofalo, B.; Buscema, M.; Valenti, G.; Rapisarda, A.M.C.; Vitale, S.G. Evidence-Based and Patient-Oriented Inositol Treatment in Polycystic Ovary Syndrome: Changing the Perspective of the Disease. Int. J. Endocrinol. Metab. 2017, 15, e43695. [CrossRef] [PubMed]

578. Laganà, A.S.; Pizzo, A. Authors' reply to: "Empiric" inositol supplementation in normal-weight non-insulin resistant women with polycystic ovarian disease: From the absence of benefit to the potential adverse effects. Arch. Gynecol. Obstet. 2015, 291, 959-960. [CrossRef] [PubMed]

579. Laganà, A.S.; Barbaro, L.; Pizzo, A. Evaluation of ovarian function and metabolic factors in women affected by polycystic ovary syndrome after treatment with D-Chiro-Inositol. Arch. Gynecol. Obstet. 2015, 291, 1181-1186. [CrossRef] [PubMed]

580. Pizzo, A.; Laganà, A.S.; Barbaro, L. Comparison between effects of myo-inositol and D-chiro-inositol on ovarian function and metabolic factors in women with PCOS. Gynecol. Endocrinol. 2014, 30, 205-208. [CrossRef] [PubMed]

581. Gulino, F.A.; Leonardi, E.; Marilli, I.; Musmeci, G.; Vitale, S.G.; Leanza, V.; Palumbo, M.A. Effect of treatment with myo-inositol on semen parameters of patients undergoing an IVF cycle: In vivo study. Gynecol. Endocrinol. 2016, 32, 65-68. [CrossRef] [PubMed]

582. Vitale, S.G.; Rossetti, P.; Corrado, F.; Rapisarda, A.M.C.; La Vignera, S.; Condorelli, R.A.; Valenti, G.; Sapia, F.; Laganà, A.S.; Buscema, M. How to Achieve High-Quality Oocytes? The Key Role of Myo-Inositol and Melatonin. Int. J. Endocrinol. 2016, 2016, 4987436. [CrossRef] [PubMed]

583. Villar, H.C.C.E.; Saconato, H.; Valente, O.; Atallah, A.N. Thyroid hormone replacement for subclinical hypothyroidism. Cochrane Database Syst. Rev. 2007. [CrossRef]

584. Aoki, Y.; Belin, R.M.; Clickner, R.; Jeffries, R.; Phillips, L.; Mahaffey, K.R. Serum TSH and total T4 in the United States population and their association with participant characteristics: National Health and Nutrition Examination Survey (NHANES 1999-2002). Thyroid 2007, 17, 1211-1223. [CrossRef] [PubMed]

585. Caldwell, K.L.; Miller, G.A.; Wang, R.Y.; Jain, R.B.; Jones, R.L. Iodine status of the U.S. population, National Health and Nutrition Examination Survey 2003-2004. Thyroid 2008, 18, 1207-1214. [CrossRef] [PubMed]

586. Delange, F.; de Benoist, B.; Burgi, H.; ICCIDD Working Group. International Council for Control of Iodine Deficiency Disorders Determining median urinary iodine concentration that indicates adequate iodine intake at population level. Bull. World Health Organ. 2002, 80, 633-636. [PubMed] 
587. Perrine, C.G.; Herrick, K.; Serdula, M.K.; Sullivan, K.M. Some subgroups of reproductive age women in the United States may be at risk for iodine deficiency. J. Nutr. 2010, 140, 1489-1494. [CrossRef] [PubMed]

588. Krajcovicová-Kudlácková, M.; Bucková, K.; Klimes, I.; Seboková, E. Iodine deficiency in vegetarians and vegans. Ann. Nutr. Metab. 2003, 47, 183-185. [CrossRef] [PubMed]

589. Waldmann, A.; Koschizke, J.W.; Leitzmann, C.; Hahn, A. Dietary intakes and lifestyle factors of a vegan population in Germany: Results from the German Vegan Study. Eur. J. Clin. Nutr. 2003, 57, 947-955. [CrossRef] [PubMed]

590. Baroni, L.; Goggi, S.; Battino, M. VegPlate: A Mediterranean-Based Food Guide for Italian Adult, Pregnant, and Lactating Vegetarians (ARTICLE IN PRESS). J. Acad. Nutr. Diet. 2017. [CrossRef] [PubMed]

2018 by the authors. Licensee MDPI, Basel, Switzerland. This article is an open access article distributed under the terms and conditions of the Creative Commons Attribution (CC BY) license (http://creativecommons.org/licenses/by/4.0/). 